\title{
O gênero Polygala L. (Polygalaceae) na região Sul do Brasil ${ }^{1}$
}

\author{
Raquel Lüdtke ${ }^{2,4}$, Tatiana Teixeira de Souza-Chies ${ }^{3}$ e Silvia Teresinha Sfoggia Miotto ${ }^{3}$
}

Recebido: 4.02.2011; aceito: 9.01.2013

\begin{abstract}
The genus Polygala L. (Polygalaceae) in Southern Brazil). In Southern Brazil, the Polygalaceae family is represented by five genera: Acanthocladus, Bredemeyera, Monnina, Polygala, and Securidaca. The genus Polygala is the largest of the Polygalaceae family, with approximately 725 species widely distributed in the world, in all types of environment. Approximately 140 taxa of Polygala are known in the Brazilian flora. The survey recorded 39 species of Polygala to Southern Brazil, representing the subgenera Hebeclada, Ligustrina and Polygala, the last one with 31 species. Full descriptions, illustrations, analytical keys, data on habitat, geographic distribution, and ecological observations are provided.
\end{abstract}

Key words: Paraná, Rio Grande do Sul, Santa Catarina, taxonomy

RESUMO - (O gênero Polygala L. (Polygalaceae) na região Sul do Brasil). A família Polygalaceae está representada por cinco gêneros no Sul do Brasil: Acanthocladus, Bredemeyera, Monnina, Polygala e Securidaca. O gênero Polygala é o mais abundante da família Polygalaceae, com aproximadamente 725 espécies mundialmente distribuídas nos mais diversos ambientes. Na flora brasileira são conhecidos 140 táxons de Polygala. Foram reconhecidas 39 espécies de Polygala para a região Sul do Brasil, pertencentes aos subgêneros Hebeclada, Ligustrina e Polygala, sendo o último o que concentra o maior número de espécies, 31. São fornecidas descrições dos táxons, ilustrações, chaves de identificação, dados sobre hábitat, distribuição geográfica e observações ecológicas.

Palavras-chave: Paraná, Rio Grande do Sul, Santa Catarina, taxonomia

\section{Introdução}

Polygala L.é o mais abundante dos 19 gêneros que compõem a cosmopolita família Polygalaceae. Com cerca de 725 espécies amplamente distribuídas pelo globo, o gênero Polygala, assim como Polygalaceae, está ausente apenas na Nova Zelândia e nas zonas ártica e antártica. De acordo com Paiva (1998), 400 espécies de Polygala são americanas, 211 africanas, 22 europeias, 60-70 asiáticas, 8-12 australianas e 1-2 introduzidas na Polinésia e na Groelândia.

Na flora brasileira, a família está representada pelos gêneros Acanthocladus Klotzsch ex Hassk., Barnhartia Gleason, Bredemeyera Willd., Diclidanthera Mart., Monnina Ruiz \& Pav., Moutabea Aublet, Polygala e Securidaca L., totalizando 191 espécies, das quais cerca de 98 espécies e 29 variedades pertencem ao gênero Polygala (Marques \& Peixoto 2007,
Pastore et al. 2012). Na região Sul do Brasil ocorrem os gêneros Acanthocladus, Bredemeyera, Monnina, Polygala e Securidaca (Lüdtke 2008, Lüdtke et al. 2008, 2009, Pastore et al. 2010, 2012).

Chodat (1893) dividiu o gênero Polygala em dez seções: Phlebotaenia Griseb., Acanthocladus ((Klotzsch ex Hassk.) Chodat), Hebecarpa Chodat, Hebeclada Chodat, Ligustrina Chodat, Gymnospora Chodat, Bachytropis DC., Semeiocardium Hassk., Chamaebuxus DC. e Polygala (=Orthopolygala Chodat).

A proposta de Paiva (1998) é a classificação mais aceita para Polygala, e nela, o gênero é dividido em 12 subgêneros: Phlebotaenia Griseb., Badiera (DC.) S.F. Blake, Hebecarpa (Chodat) Blake, Acanthocladus (Klotzsch ex Hassk.) Paiva, Ligustrina (Chodat) Paiva, Brachytropis (DC.) Paiva, Gymnospora (Chodat) Paiva, Hebeclada (Chodat) S.F. Blake, Rhinotropis

1. Parte da Tese de Doutorado da primeira Autora

2. Universidade Federal de Pelotas, Instituto de Biologia, Departamento de Botânica, Campus Capão do Leão, Caixa Postal 354, 96010-900 Pelotas, RS, Brasil

3. Universidade Federal do Rio Grande do Sul, Programa de Pós-Graduação em Botânica, Av. Bento Gonçalves 9500, Bloco IV, Prédio 43433, Bairro Agronomia, 91501-970 Porto Alegre, RS, Brasil

4. Autor para correspondência: raquelludtke@yahoo.com.br 
(S.F. Blake) Paiva, Chodatia Paiva, Chamaebuxus (DC.) Duch. e Polygala, sendo que, atualmente, Acanthocladus é reconhecido como um gênero (Pastore et al. 2010).

Os subgêneros Ligustrina, Gymnospora, Hebeclada e Polygala têm representantes no Brasil e todos já tiveram sua taxonomia estudada para a flora brasileira (Marques 1979, 1984a, b, 2003, Marques \& Peixoto 2007, Aguiar, 2005, Aguiar et al. 2008).

Além de estudos taxonômicos, inúmeros trabalhos farmacológicos há muito são realizados com Polygala devido ao grande potencial fitoterápico presente nas espécies do gênero. Um exemplo é Polygala senega L., a primeira a ser investigada quanto ao aspecto químico e comprovadamente eficaz contra bronquite crônica e faringite (Resolução ${ }^{\circ}$ 89, de 16 de março de 2004 da Agência Nacional de Vigilância Sanitária). Além dessa espécie, muitos representantes da família têm sido alvo de estudos fitoquímicos, imunológicos e neurológicos (Ikeya et al. 1991, Daros et al. 1996, Pereira et al. 1996, Monzou et al. 1999, Chung et al. 2002, Obi et al. 2002, Pizzolattii et al. 2004).

O uso terapêutico comprovado do salicilato de metila e de algumas saponinas (Harbone \& Baxter 1995) tem despertado o interesse na família Polygalaceae, justificando a relevância de estudos taxonômicos com a família.

O objetivo deste trabalho é enriquecer o conhecimento da família Polygalaceae, em especial do gênero Polygala, dando continuidade aos estudos taxonômicos da família na região Sul do Brasil (Lüdtke \& Miotto 2004, Lüdtke et al. 2008, 2009).

\section{Material e métodos}

Foram analisadas cerca de 3.500 exsicatas pertencentes a 38 herbários nacionais e internacionais, cujas siglas estão referidas de acordo com o Index Herbariorum (Holmgren \& Holmgren 2008): B, BHCB, BLA, C, CEN, CNPO, CTES, EPCB, F, FLOR, FUEL, GH, HAS, HB, HBR, HERULBRA, HUCS, HUEM, HUPG, HURG, ICN, JOIN, LIL, LP, MA, MBM, MPUC, NY, P, PACA, PEL, RB, S, SMDB, SP, U, UEC e UPCB. Destes, não são indexados o Herbário da Universidade de Caxias do Sul, Caxias do Sul, RS (HUCS, sigla não oficial), da EMBRAPA Pecuária Sul, Bagé, RS (CNPO, sigla não oficial) e da Universidade Luterana do Brasil (HERULBRA, sigla não oficial).

Foram realizadas dezoito expedições de campo nos três Estados da região Sul do Brasil com a finalidade de coleta e observações adicionais referentes aos eventos de floração, frutificação e dos ambientes de ocorrência. O material coletado está depositado no Herbário do Instituto de Biociências da Universidade Federal do Rio Grande do Sul (ICN), Porto Alegre, RS.

A categoria infra-específica variedade não foi adotada para as espécies de Polygala no presente trabalho. Acredita-se ser subjetiva a delimitação de variedades em um gênero que apresenta ampla variação de formas e dimensões dentro de uma mesma espécie, variação essa atribuída à plasticidade fenotípica dos indivíduos. Portanto, todas as variedades citadas para a região Sul do Brasil não foram consideradas no presente trabalho.

As medidas das estruturas representam os valores extremos encontrados entre os indivíduos analisados. A terminologia utilizada nas descrições dos caracteres morfológicos segue Radford et al. (1974), Font Quer (1979), Marques (1979), Pastore (2006), Marques \& Peixoto (2007) e Aguiar et al. (2008).

No material examinado, os nomes antigos dos municípios estão citados entre parênteses, logo após os nomes atuais. A distribuição geográfica, dados sobre floração e frutificação e caracterização dos ambientes de cada espécie foram baseados na literatura especializada, nas informações obtidas nas etiquetas das exsicatas analisadas e nas observações realizadas durante as viagens de coleta. Os desenhos dos hábitos foram realizados a partir de cópias reprográficas das exsicatas e as ilustrações dos detalhes foram elaboradas com o auxílio de uma câmara-clara acoplada a microscópio estereoscópico Meiji Techno RZ. As pranchas completas de cada espécie podem ser encontradas em Lüdtke (2008).

\section{Resultados e Discussão}

\section{Polygala L.}

Espécie-tipo: Polygala vulgaris L., Sp. Pl. ed. 1: 701. 1753.

Ervas, subarbustos, arbustos, raramente árvores. Caule subáfilo ou folioso, com ou sem glândulas, piloso ou glabro, inerme ou com espinhos. Folhas simples, alternas, verticiladas, subverticiladas ou opostas, glandulosas ou não, com ou sem nectários extraflorais (glândulas laterais) na base do pecíolo. Inflorescência do tipo racemo ou, menos frequentemente, fascículo, séssil, subséssil ou pedunculado, terminal, axilar, extra-axilar ou opositifólio, densifloro ou laxifloro. Flores diclamídeas, bissexuais, brancas, branco-esverdeadas, esverdeadas, branco-rosadas, rosadas, creme, creme-esverdeadas, 
lilases, violáceas, roxas, magenta, purpúreas ou azuis, sésseis ou pediceladas, pedicelo tribracteado, com ou sem nectários extraflorais (glândulas laterais) na base. Cálice pentâmero, persistente no fruto, formado por cinco sépalas divididas em duas séries, uma externa, formada por três sépalas menores, unidas ou livres entre si, glabras ou pilosas, com ou sem glândulas; uma série interna formada por duas sépalas internas, petaloides. Corola pentâmera ou trímera, zigomorfa, formada por duas pétalas laterais aderidas lateralmente à bainha estaminal; uma pétala central denominada carena ou quilha, com ápice cristado, trilobado ou inteiro e, se pentâmera, a corola apresenta ainda um par de pétalas laterais diminutas, rudimentares. Oito estames unidos pelos filetes, formando uma bainha estaminal funcionalmente tubulosa, anteras basifixas e poricidas. Ovário súpero, bicarpelar, bilocular, com dois rudimentos seminais, glabro ou piloso, com ou sem glândulas. Estilete terminal, simples, reto ou falcado, uncinado ou geniculado, frequentemente dilatado na porção apical, terminando muitas vezes em uma cavidade pré-estigmática. Estigma geralmente globoso, situado na extremidade superior ou inferior da cavidade pré-estigmática, com ou sem tufo de tricomas no ápice. Cápsula bivalvar, rimosa, loculicida, glabra ou pilosa, com ou sem glândulas, estipitada ou não, alada ou não. Duas sementes negras, glabras, pubérulas ou pubescentes, com ou sem carúncula, com ou sem apêndice membranáceo bilobado (Marques 1979, Eriksen \& Persson 2007, Aguiar et al. 2008).

Na região Sul do Brasil o gênero Polygala está representado pelos subgêneros Hebeclada (seis espécies), Ligustrina (duas espécies) e Polygala (31 espécies), totalizando 39 espécies.

Chave para a identificação dos subgêneros de Polygala da região Sul do Brasil

1. Carena com ápice cristado ...3. Polygala subg. Polygala 1. Carena com ápice simples ou trilobado, nunca cristado

2. Nectários extraflorais presentes na base do pecíolo e do pedicelo; sementes subtriangulares, sem tricomas seríceos, carúncula prolongada em um apêndice livre, carnoso ......... 2. Polygala subg. Ligustrina

2. Nectários extraflorais ausentes na base do pecíolo e do pedicelo; sementes suborbiculares, oblongas ou cilíndricas, com tricomas seríceos, carúncula com dois apêndices unidos, córneos ou fimbriada 1. Polygala subg. Hebeclada
1. Polygala L. subgênero Hebeclada (Chodat) S.F. Blake, Contr. Gray Herb., ser. 2, 47: 59. 1916.

Espécie-tipo: Polygala hebeclada DC., Prod. 1: 331. 1824.

Ervas ou subarbustos. Ausência de nectários extraflorais na base do pecíolo e do pedicelo. Flores reunidas em racemos terminais ou subterminais. Cálice pentâmero, persistente no fruto; sépalas externas com ou sem tricomas glandulares; as abaxiais unidas em quase toda a sua extensão. Corola trímera a pentâmera; carena com ápice não cristado, trilobado; pétalas laterais rudimentares presentes ou não, aderidas ao dorso da bainha estaminal. Gineceu com ovário circundado ou não por um disco na base; estilete curvo, formando um ângulo de $90^{\circ}$ no terço apical, tricomas simples em forma de "U"; estigma globoso. Sementes suborbiculares, oblongas ou cilíndricas, revestidas de tricomas seríceos, carúncula com dois apêndices unidos, córneos ou fimbriada.

O subgênero Hebeclada é neotropical, distribuído desde o sul dos Estados Unidos até o norte da Argentina, com centro de diversidade na região Centro-Oeste do Brasil, no domínio do Cerrado. No Brasil são reconhecidas 12 espécies e cinco variedades (Aguiar et al. 2008); para a região Sul do Brasil foram confirmadas seis espécies.

Chave para a identificação das espécies de Polygala subg. Hebeclada para a região Sul do Brasil

1. Margem das sépalas externas com tricomas glandulares

2. Disco ausente na base do ovário
3. Cápsula alada 1. P. extraaxillaris

3. Cápsula não alada 6. P. violacea

2. Disco presente na base do ovário

4. Pedicelos reflexos, 3-5 mm compr.; sépalas internas sem nervuras proeminentes 5. P. rhodoptera

4. Pedicelos eretos, 0,5-2 mm compr.; sépalas internas com nervuras proeminentes 3. P. hebeclada

1. Margem das sépalas externas sem tricomas glandulares

5. Plantas com indumento hirsuto; racemos 0,8-1,3 cm compr.; cápsula não alada 4. P. hirsuta

5. Plantas sem indumento hirsuto; racemos 1-11 cm compr.; cápsula alada ....... 2. P. fimbriata 
1.1. Polygala extraaxillaris Chod., Mém. Soc. Phys. et d'Hist. Nat. Genève 31: 58. 1893.

Figura 1a-d

Subarbustos eretos, 7-57 cm alt. Caule folioso, cilíndrico, densamente piloso, com tricomas curtos, sem glândulas. Folhas pecioladas, alternas, lâminas 3,6-63 × 2-18 mm, papiráceas, pilosas, sem glândulas, lineares, estreito-elípticas a largo-elípticas, ápice agudo, base aguda, margem inteira, ciliada; pecíolos 1-3 mm compr. Brácteas e bractéolas decíduas, margem ciliada. Racemos pedunculados, terminais, extra-axilares ou axilares, cilíndricos, laxifloros, 1,5-12 cm compr. Flores 5-7 mm compr., esverdeadas, branco-rosadas, rosadas ou lilases; pedicelos 2-4 mm compr., pilosos, reflexos na frutificação. Sépalas externas pilosas, sem glândulas, ápice agudo, margem com tricomas glandulares, uma sépala estreito-ovada a ovada, 2,5-3,5 mm compr., duas sépalas iguais e concrescidas entre si, estreito-ovadas a ovadas, 2-3,1 mm compr.; sépalas internas glabras, sem glândulas, obovadas, 5-7,5 mm compr., ápice arredondado ou ondulado irregular, base atenuada. Pétalas laterais desenvolvidas, pilosas internamente, na parte basal ou na margem, sem glândulas, espatuladas, 3,5-5 $\mathrm{mm}$ compr., ápice ondulado; pétalas laterais rudimentares lineares, $2 \mathrm{~mm}$ compr.; carena trilobada, lobo central cuculado, laterais plicado-pregueados, 4-5 $\mathrm{mm}$ compr., fortemente unguiculada, sem glândulas, glabra. Ovário glabro, sem glândulas, elíptico, sem disco na base. Cápsulas glabras, sem glândulas, elípticas, 4-6,2 mm compr., levemente estipitadas, aladas, emarginadas em ambos os bordos. Sementes oblongas ou cilíndricas, 3-4 mm compr., densamente pubescentes, com tricomas seríceos, longos, prateados; carúncula córnea 0,9-1,3 mm compr., com um apêndice dorsal e dois laterais.

Material selecionado: BRASIL. PARANÁ: Arapoti, Rio das Cinzas, Barra do Perdizes, 23-X-1961, G. Hatschbach 8783 (MBM); Guarapuava, PR 460, $25^{\circ} 14^{\prime} 59,9^{\prime \prime} \mathrm{S}, 51^{\circ} 32^{\prime} 19,1^{\prime \prime} \mathrm{W}, 20-\mathrm{XII}-2006$, R. Lüdtke 689 (ICN); Ipiranga, Rio Tibagi, 14-XI-1957, G. Hatschbach 4526 (MBM); Palmeira, Fazenda Santa Rita, 28-I-1981, L. Dombrowski 12479 (MBM); Ponta Grossa, Rodovia do Café, 6 km E de Vila Velha, 11-X-1977, E. Forero 3742 (MBM). Rio Grande do Sul: Caçapava do Sul, BR 153, km 471, 27-XII-2004, R. Lüdtke 356 (ICN); Cambará do Sul, II-1948, B. Rambo 36165 (PACA); Carazinho,
8-X-1970, J.F.M. Valls \& A. Pott 1305 (BLA); Coronel Bicaco, BR 468, km 28, 4-XI-2003, R. Lüdtke 201 (ICN); Guaíba, Fazenda São Maximiano, 2-IV-2003, R. Lüdtke 189 (ICN); Pejuçara, BR 158, a $3 \mathrm{~km}$ do trevo para Pejuçara em direção a Cruz Alta, 26-XII-2002, R. Lüdtke 97 (ICN); Santana do Livramento, Cerro Palomas, 9-I-2003, R. Lüdtke 139 (ICN); São Miguel das Missões, estrada secundária em direção a São Lourenço das Missões, 5-XI-2003, R. Lüdtke 208 (ICN); Uruguaiana, BR 290, km 213, I-1972, A. Pott 7 (BLA). SAnta Catarina: Abelardo Luz, entre Abelardo Luz e a BR 280, 26 $31^{\prime} 35,8^{\prime \prime} \mathrm{S}$, $52^{\circ} 16^{\prime} 31,4^{\prime \prime} \mathrm{W}, 18-\mathrm{XII}-2006$, R. Lüdtke 679 (ICN); Campos Novos, na estrada vicinal para Celso Ramos, a $5 \mathrm{~km}$ da BR $470,27^{\circ} 33^{\prime} 59,0^{\prime \prime} \mathrm{S}, 51^{\circ} 23^{\prime} 24,5^{\prime \prime} \mathrm{W}$, 14-XII-2004, R. Lüdtke 333 (ICN); Capão Alto, BR 116, km 291, 2806'34,0"S, 50³7'13,4"W, 21-XII-2006, R. Lüdtke 690 (ICN). Curitibanos, BR 470, km 258, para Campos Novos, 2718'29,9"S, $50^{\circ} 38^{\prime} 41,5^{\prime \prime} \mathrm{W}, 14-\mathrm{XII}-2004$, R. Lüdtke 328 (ICN); São Joaquim, $\mathrm{km} 45,5$ da rodovia Lages-São Joaquim, 20-X-2004, R. Lüdtke 265 (ICN).

Polygala extraaxillaris ocorre no Paraguai, Argentina e Brasil: Paraná, Santa Catarina e Rio Grande do Sul (Grondona 1948, Wurdack \& Smith 1971, Marques 1979, Bernardi 2000, Lüdtke \& Miotto 2004, Aguiar et al. 2008). É encontrada em beira de estradas alteradas por queimadas, em campos limpos, arbustivos, solos secos ou úmidos, em morros graníticos. Floresce e frutifica de agosto a abril.

A inflorescência extra-axilar é uma importante característica diagnóstica desta espécie, uma vez que esse tipo de inflorescência, dentre as espécies do subgênero que ocorrem na região Sul do Brasil, é percebida somente em Polygala extraaxillaris. Pode ser confundida com $P$. rhodoptera e P. hebeclada pelo hábito, pela presença de tricomas glandulares nas margens das sépalas externas e pela semelhança das sementes (com tricomas longos e prateados e com carúncula córnea); mas $P$. extraaxillaris não apresenta um disco na base do ovário e suas cápsulas são aladas e estipitadas, enquanto que em $P$. rhodoptera e $P$. hebeclada as cápsulas são desprovidas de alas e de estípite.

1.2. Polygala fimbriata A.W. Benn., F1. Bras. 13(3): 13. 1874.

Figura 1e-g

Subarbustos eretos, $25 \mathrm{~cm}$ a $1,5 \mathrm{~m}$ alt. Caule cilíndrico, estriado, densamente pubescente, tricomas patentes, sem glândulas. Folhas pecioladas, alternas, 

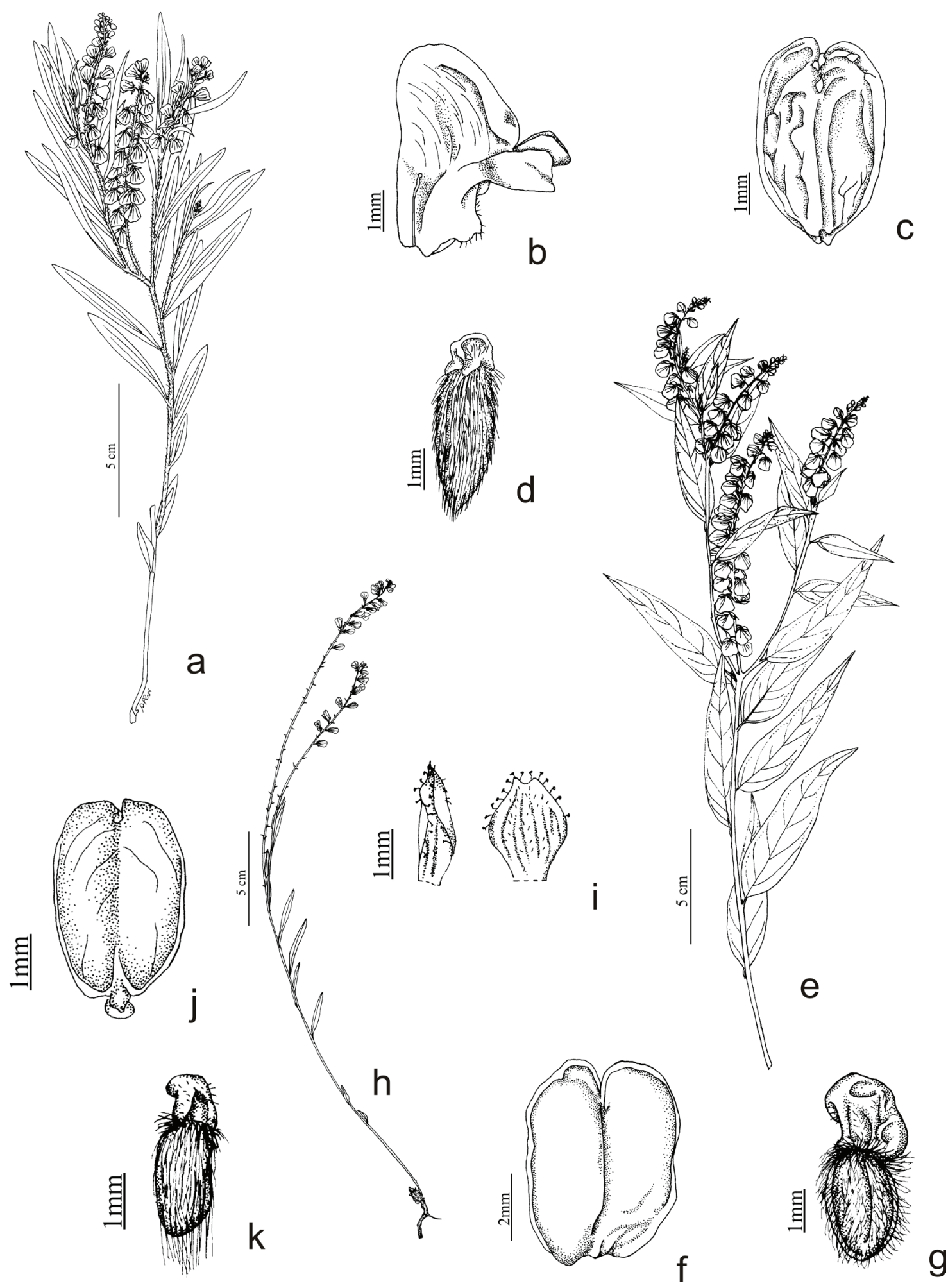

Figura 1. a-d. Polygala extraaxillaris. a. Hábito. b. Corola em vista lateral. c. Fruto. d. Semente. e-g. Polygala fimbriata. e. Hábito. f. Fruto. g. Semente. h-k. Polygala hebeclada. h. Hábito. i. Sépalas externas. j. Fruto. k. Semente. [a: Malme 242B (S); b-d: Lüdtke 139 (ICN); e-g: Dusén 15926 (GH); h-k: Lüdtke 681 (ICN)].

Figure 1. a-d. Polygala extraaxillaris. a. Habit. b. Corolla in lateral view. c. Fruit. d. Seed. e-g. Polygala fimbriata. e. Habit. f. Fruit. g. Seed. h-k. Polygala hebeclada. h. Habit. i. External sepals. j. Fruit. k. Seed. [a: Malme 242B (S); b-d: Lüdtke 139 (ICN); e-g: Dusén 15926 (GH); h-k: Lüdtke 681 (ICN)]. 
lâminas 15-100 × 8-45 mm, membranáceas a papiráceas, pubescentes, sem glândulas, elípticas, lanceoladas ou ovadas, ápice agudo, acuminado, apiculado ou retuso, base aguda, assimétrica, margem revoluta, ciliada; pecíolos 2-4 mm compr. Brácteas e bractéolas decíduas, margem ciliada. Racemos pedunculados, terminais ou opositifólios, cilíndricos, 3-11 cm compr., laxifloros. Flores 2-8 mm compr., rosadas ou lilases; pedicelos 2-3,1 mm compr., glabros, reflexos na frutificação. Sépalas externas glabras, sem glândulas, ápice agudo, margem ciliada, sem tricomas glandulares; uma sépala ovado-côncava, 3-4 mm compr.; duas sépalas iguais e concrescidas entre si, ovadas, 2,6-3,5 mm compr.; sépalas internas ciliadas na margem, sem glândulas, largo-ovadas a suborbiculares, 6-7,2 mm compr., ápice arredondado, base cuneada. Pétalas laterais desenvolvidas, densamente pilosas internamente na base, sem glândulas, elípticas, 4-5,2 mm compr., ápice flabeliforme; pétalas laterais rudimentares, lineares, 0,8-2 mm compr.; carena trilobada, lobo central cuculado, laterais plicado-pregueados, 4-4,2 mm compr., fortemente unguiculada, sem glândulas, pilosa internamente. Ovário glabro, sem glândulas, oblongo a suborbicular, com disco na base. Cápsulas glabras, sem glândulas, largo-oblongas a suborbiculares, 5,2-7 mm compr., não estipitadas, aladas, emarginadas nos dois bordos. Sementes globosas, 4,2-5 mm compr., densamente pubescentes, com uma coroa de tricomas abaixo da carúncula, testa com sulcos longitudinais, carúncula carnosa, fimbriada, enrugada, pubérula, 2-3 mm compr., sem apêndices córneos.

Material selecionado: BRASIL. ParanÁ: Arapoti, Fazenda Barra Mansa, 23-I-1990, J. Mattos 1799 (MBM); Cianorte, na estrada de Araruna para Cianorte, 2350'08,9"S, 52³6'39,7"W, 19-XII-2006, R. Lüdtke 684 (ICN); Jaguariaíva, $24^{\circ} 14^{\prime} \mathrm{S}, 49^{\circ} 41^{\prime} \mathrm{W}$, 28-V-1997, A.C. Cervi et al. 6274 (UPCB, MBM, NY); Londrina, EMAUS, próximo da rodovia Londrina-São Luiz, 31-VIII-1996, G.A. Berg s.n. (FUEL30094); Ortigueira, Estação da Copel-Basílio, 15-XI-1998, J.A. Ferreira \& O.C. Pavão s.n. (UEC131531, FUEL30088); São Jerônimo da Serra, Reserva Indígena São Jerônimo, 19-IX-2002, K.L.V.R. Sá et al. 326 (FUEL); Telêmaco Borba, Reserva Biológica S. Klabin, 7-X-1986, G. Hatschbach 50613 (MBM, RB); Tibagi, Fazenda Monte Alegre, Harmonia, 12-X-1952, G. Hatschbach 2926 (MBM).

Polygala fimbriata ocorre somente no Brasil: Minas Gerais, Rio de Janeiro, São Paulo e Paraná
(Bernardi 2000, Marques \& Gomes 2002, Aguiar et al. 2008). Geralmente é encontrada associada a cursos d'água, com solos muito úmidos, em locais sombreados como beira de matas, capoeiras, matas de galeria e em Floresta Ombrófila Densa. Floresce e frutifica de outubro a maio.

Polygala fimbriata além de não possuir tricomas glandulares na margem das sépalas externas, possui sementes inconfundíveis, apresentando sulcos longitudinais na testa e uma carúncula fimbriada, carnosa sem apêndices córneos.

1.3. Polygala hebeclada DC., Prod. 1: 331. 1824.

$=$ P. hyssopifolia A. St.-Hil. \& Moq., Ann Soc. Roy. Sci. Art. Orleans, 9: 53. 1828.

Figura $1 \mathrm{~h}-\mathrm{k}$

Subarbustos eretos, 9-63 cm alt. Caule cilíndrico, densamente pubescente; tricomas patentes, sem glândulas. Folhas pecioladas, alternas, lâminas 9-45 × 1-8 mm, cartáceas, pubescentes, sem glândulas, estreito-elípticas a lineares, ápice agudo, acuminado ou apiculado, base cuneada, margem revoluta, ciliada; pecíolos 1-2 mm compr. Brácteas e bractéolas tardiamente decíduas ou persistentes, margem densamente ciliada. Racemos pedunculados, terminais, cilíndricos, 3-25 cm compr., laxifloros. Flores 5-7 mm compr., rosadas ou lilases, pedicelos 0,5-2 mm compr., glabros ou pubérulos, nunca reflexos, eretos na floração e na frutificação. Sépalas externas pubérulas, sem glândulas, ápice agudo ou obtuso, margem com tricomas glandulares, uma sépala ovada, 2-2,5 mm compr., duas sépalas iguais e concrescidas entre si, elípticas, 1,5-2 mm compr.; sépalas internas com nervuras proeminentes, bem marcadas, ciliadas ou não na margem, sem glândulas, obovadas ou oblongas, 5-6,2 mm compr., ápice cuculado e arredondado, base atenuada. Pétalas laterais desenvolvidas, pilosas internamente na base, sem glândulas, oblongas, 3-4,5 mm compr., ápice arredondado; pétalas laterais rudimentares lineares, 1-1,5 mm compr.; carena trilobada, lobo central cuculado, laterais plicado-pregueados, 4-5 mm compr., fortemente unguiculada, sem glândulas, glabra. Ovário glabro, sem glândulas, oblongo, com disco na base. Cápsulas glabras, sem glândulas, oblongas, 4-5,3 mm compr., não estipitadas, não aladas. Sementes oblongas, 3-3,8 mm compr., densamente pubescentes, adpresso-seríceas, tricomas prateados ultrapassando o comprimento da semente, carúncula córnea, $1 \mathrm{~mm}$ compr., com um apêndice dorsal e dois laterais. 
Material selecionado: BRASIL. PARANÁ: Carambeí,

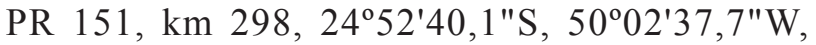
23-II-2006, R. Lüdtke 539 (ICN); Cêrro Azul, Serra da Canha, 27-I-1970, G. Hatschbach \& O. Guimarães 23422 (MBM, NY); Curitiba, Rio Atuba, 30-X-1973, G. Hatschbach 32763 (MBM); Ipiranga, BR 373,

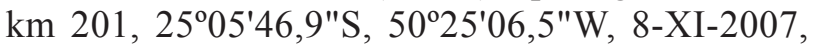
R. Lüdtke 806 (ICN); Mangueirinha, PR 449, $26^{\circ} 20^{\prime} 06,3^{\prime \prime} \mathrm{S}, 52^{\circ} 07^{\prime} 01,6^{\prime \prime} \mathrm{W}, 18-\mathrm{XII}-2006$, R. Lüdtke 681 (ICN); Palmeira, BR 277, no trevo com a PR 151,

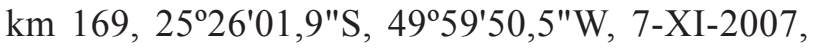
R. Lüdtke 794 (ICN); Ponta Grossa, entrada do Parque de Vila Velha, $25^{\circ} 14 ' 45,0^{\prime \prime}$ S, 5001'17,5"W, 11-I-2007, R. Lüdtke 746 (ICN); Quatro Barras (Campina Grande do Sul), 22-X-1961, G. Hatschbach 8504 (MBM); Ventania, Morro do Chapéu, $18 \mathrm{~km}$ estrada Ventania-Ibaiti, 8-VI-2005, D.A. Estevan et al. 739 (FUEL, ICN). Santa Catarina: Lages, junto a cidade, 18-II-1958, J. Mattos 5905 (HAS); idem, Morro do Pinheiro Seco, 17-XII-1962, R. Reitz \& R. Klein 13975 (HBR).

Polygala hebeclada ocorre no Brasil: Mato Grosso, Goiás, Distrito Federal, Minas Gerais, Espírito Santo, Rio de Janeiro, São Paulo, Paraná e Santa Catarina (Wurdack \& Smith 1971, Marques 1979, Marques \& Gomes 2002, Aguiar et al. 2008). Pode ser encontrada em campos limpos ou arbustivos, campos rupestres e campos cerrados, beira de estradas, em solos secos ou úmidos. Floresce e frutifica de outubro a junho.

Polygala hebeclada apresenta as brácteas persistentes após a frutificação, sépalas externas com tricomas glandulares na margem e nervuras bem marcadas, além do disco que envolve o ovário. Pode ser confundida com $P$. rhodoptera, porém, nesta, as sépalas internas não apresentam uma nervação proeminente como percebida em $P$. hebeclada. Além disso, o pedicelo de $P$. rhodoptera é sempre reflexo e nitidamente maior, com 3-5 $\mathrm{mm}$ de comprimento, enquanto que em $P$. hebeclada o pedicelo é ereto alcançando apenas 0,5-2 $\mathrm{mm}$ de comprimento.

1.4. Polygala hirsuta A. St.-Hil. \& Moq., Mém. Mus. Hist. Nat. Paris 17: 336. 1828.

Figura 2a-d

Ervas a subarbustos eretos, 6-9 $\mathrm{cm}$ alt. Caule cilíndrico, densamente pilosos, tricomas hirsutos, sem glândulas. Folhas pecioladas, alternas, lâminas 3-27 × 2-13 mm, cartáceas a subcoriáceas, hirsutas, sem glândulas, ovadas ou elípticas, ápice agudo, base obtusa, margem inteira, longo-ciliada; pecíolos
1-2 mm compr. Brácteas e bractéolas decíduas, margem densamente ciliada. Racemos pedunculados, terminais, cilíndricos, 0,8-1,3 cm compr., densifloros. Flores 4-5 mm compr., lilases; pedicelos 3-4 mm compr., glabros, reflexos na frutificação. Sépalas externas glabras, sem glândulas, ápice agudo, margem ciliada, sem tricomas glandulares, uma sépala ovado-côncava, 2,3-2,5 mm compr., duas sépalas iguais, concrescidas entre si, ovadas, 1,8-2 mm compr.; sépalas internas ciliadas na margem, sem glândulas, suborbiculares, 4,5-5 mm compr., ápice arredondado, base atenuada. Pétalas laterais desenvolvidas, pilosas internamente na base, sem glândulas, elíptico-assimétricas, 3,5-3,6 mm compr., com ápice arredondado; pétalas laterais rudimentares estreito-elípticas, $1 \mathrm{~mm}$ compr.; carena trilobada, lobo central cuculado, laterais plicado-pregueados, 4-4,3 mm compr., fortemente unguiculada, sem glândulas, margem pilosa. Ovário glabro, sem glândulas, oblongo a suborbicular, com disco na base. Cápsulas glabras, sem glândulas, oblongas, 3,2-5,2 mm compr., não estipitadas, não aladas. Sementes oblongas, 3-4,2 mm compr., densamente pilosas, adpresso-seríceas, tricomas prateados, ultrapassando o comprimento da semente, carúncula córnea, 0,5-1,2 mm compr., com um apêndice dorsal e dois laterais.

Material examinado: BRASIL. PARAnÁ: Arapoti, Fazenda do Tigre, 28-XI-1959, G. Hatschbach 6557 (MBM); Jaguariaíva, 9-X-1911, P. Dusén 13137 (S); idem, 27-XI-1914, P. Dusén 15917 (S); idem, rio Cilada,17-XI-1970, G. Hatschbach \& O. Guimarães 25441 (MBM); Tibagi, Fazenda Ingrata, 31-I-1959, G. Hatschbach 5469 (MBM).

Polygala hirsuta ocorre no Brasil: Maranhão, Bahia, Mato Grosso, Goiás, Distrito Federal, Minas Gerais, São Paulo e Paraná (Bernardi 2000, Marques \& Gomes 2002, Aguiar et al. 2008). É encontrada em campos arenosos ou Cerrados. Floresce e frutifica de outubro a janeiro.

Esta espécie é facilmente reconhecida por sua intensa pilosidade. As plantas são cobertas por indumento hirsuto. Além disso, as sépalas externas não possuem tricomas glandulares na margem, o ovário apresenta disco na base e a cápsula é desprovida de alas.

1.5. Polygala rhodoptera Mart. ex A.W. Benn., Fl. Bras. 13(3): 13. 1874.

Figura 2e-h

Subarbustos eretos, $47-80 \mathrm{~cm}$ alt. Caule cilíndrico, estriado, densamente pubescente, tricomas patentes, sem glândulas. Folhas pecioladas, alternas, lâminas 


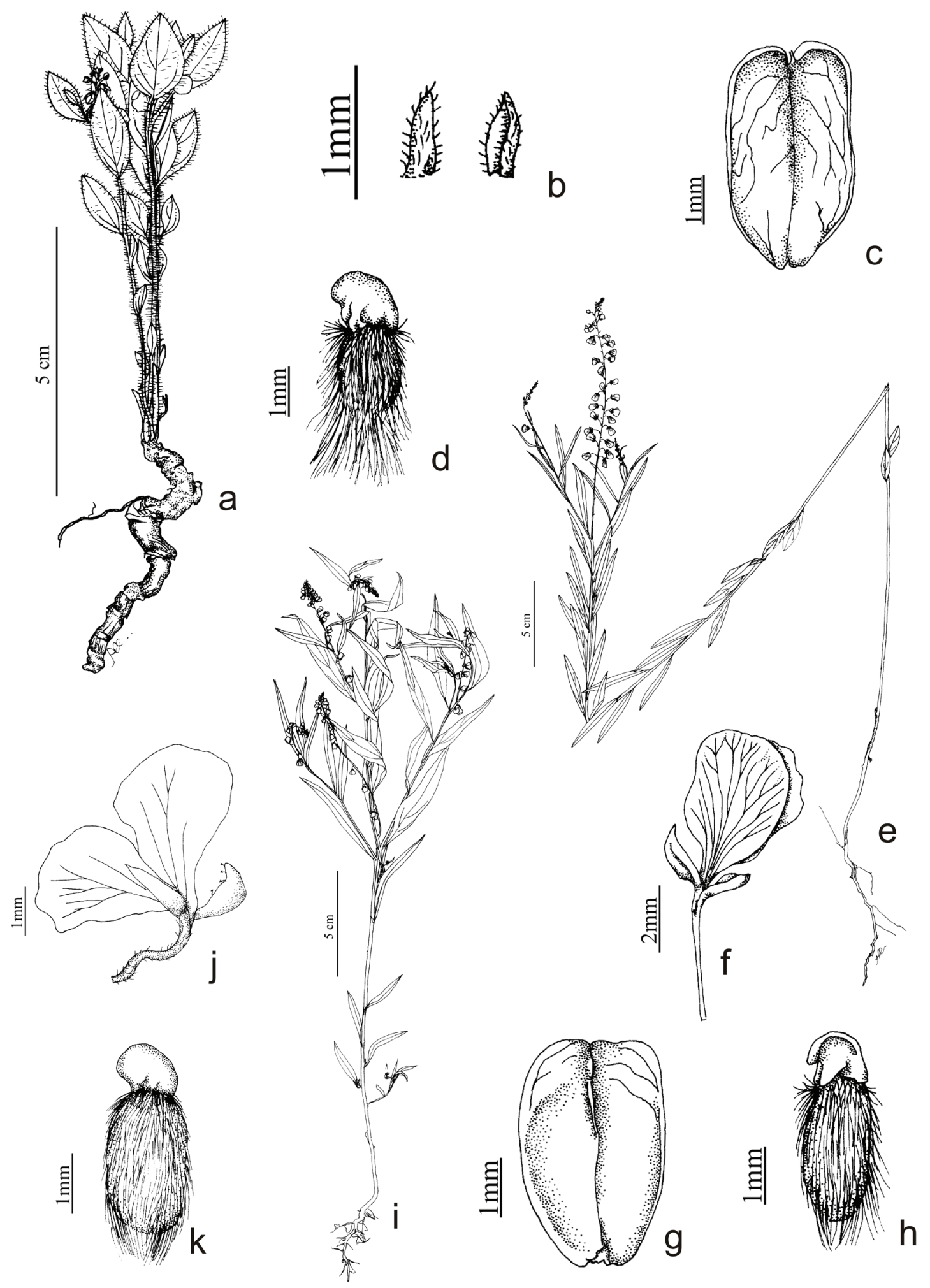

Figura 2. a-d. Polygala hirsuta. a. Hábito. b. Bráctea e bractéola. c. Fruto. d. Semente. e-h. Polygala rhodoptera. e. Hábito. f. Cálice. g. Fruto. h. Semente. i-k. Polygala violacea. i. Hábito. j. Cálice. k. Semente. [a: Dusén 13137 (G); b-c: Dusén 15917 (S); d: Hatschbach 6557 (MBM); e-h: Hatschbach \& Guimarães 19093 (MBM); i-k: Carneiro 1399 (MBM)].

Figure 2. a-d. Polygala hirsuta. a. Habit. b. Bract and bracteole. c. Fruit. d. Seed. e-h. Polygala rhodoptera. e. Habit. f. Calyx. g. Fruit. h. Seed. i-k. Polygala violacea. i. Habit. j. Calyx. k. Seed. [a: Dusén 13137 (G); b-c: Dusén 15917 (S); d: Hatschbach 6557 (MBM); e-h: Hatschbach \& Guimarães 19093 (MBM); i-k: Carneiro 1399 (MBM)]. 
20-44 × 1,5-7 mm, cartáceas, pubérulas, sem glândulas, estreito-elípticas a lineares, ápice agudo, acuminado ou apiculado base atenuada ou cuneada, margem revoluta, ciliada; pecíolos 1,5-3 mm compr. Brácteas e bractéolas tardiamente decíduas ou persistentes, margem ciliada. Racemos pedunculados, terminais, cilíndricos, 2,5-18 cm compr., laxifloros. Flores 4,5-5,5 mm compr., rosadas ou lilases; pedicelos 3-5 mm compr., pubérulos, reflexos na floração e na frutificação. Sépalas externas glabras, sem glândulas, ápice agudo, margem com tricomas glandulares; uma sépala largo-ovada, 2-2,5 mm compr.; duas sépalas iguais e concrescidas entre si, ovadas, 1,8-2 mm compr.; sépalas internas sem nervuras proeminentes, glabras, sem glândulas, obovadas a suborbiculares, 4-5,2 mm compr., ápice arredondado, base atenuada. Pétalas laterais desenvolvidas, pilosas internamente na base, sem glândulas, elípticas, 4-4,2 mm compr., com ápice arredondado; pétalas laterais rudimentares estreito-elípticas, $1 \mathrm{~mm}$ compr.; carena trilobada, lobo central cuculado, laterais plicado-pregueados, 4,5-4,8 mm compr., fortemente unguiculada, sem glândulas, glabra. Ovário glabro, sem glândulas, elíptico, com disco na base. Cápsulas glabras, sem glândulas, oblongas, 4,2-5,5 mm compr., não estipitadas, levemente emarginadas. Sementes oblongas, 3-3,1 mm compr., densamente pilosas, adpresso-seríceas, tricomas prateados, ultrapassando o comprimento da semente, carúncula córnea, 0,5-1 mm compr., com um apêndice dorsal e dois laterais.

Material examinado: BRASIL. PARANÁ: Guaíra, Parque Nacional de Sete Quedas, 9-VII-1950, L. de Camargo s.n. (MBM244875); idem, 6-IX-1961, G. Hatschbach 7506 (MBM); idem, 22-IV-1968, G. Hatschbach \& O. Guimarães 19093 (MBM); idem, 24-I-1967, J.C. Lindeman \& J.H. de Haas 4422 (F); idem, 24-III-1977, G. Hatschbach 39834 (MBM).

Polygala rhodoptera ocorre no Brasil: Bahia, Mato Grosso, Goiás, Distrito Federal, Minas Gerais (Aguiar et al. 2008) e aqui, pela primeira vez, é citada para o Estado do Paraná. Encontrada em campos limpos e rupestres, junto a corredeiras, em locais úmidos. No Paraná esta espécie foi coletada apenas em Guaíra, onde hoje está instalada a Hidroelétrica Itaipu, e a última coleta foi realizada há mais de trinta e cinco anos (1977), portanto, possivelmente, esteja extinta no Estado. Floresce e frutifica de julho a abril.

Polygala rhodoptera pode ser confundida com $P$. hebeclada, e as diferenças entre ambas estão discutidas nas observações referentes a esta última espécie. Além disso, as sépalas internas não apresentam nervuras proeminentes como se verifica em P. hebeclada. O formato das sépalas internas também é um caráter relevante para a separação destas duas espécies. Em P. rhodoptera as sépalas internas são mais largas, variando de obovadas a suborbiculares, membranáceas, com 4-5,2 mm de comprimento, enquanto que em $P$. hebeclada, essas estruturas são obovadas ou oblongas, com 5-6,2 mm de comprimento, apresentando uma consistência mais papirácea.

1.6. Polygala violacea Aubl. emend. Marques, Rodriguésia 48: 175. 1979. P. violacea Aubl., Hist. Pl. Guian. Franc. 2: 735. 1775.

$=$ P. bryzoides A. St.-Hil. \& Moq., Fl. Bras. Mer. 2:44. 1829 .

Figura 2i-k

Subarbustos eretos, $32-50 \mathrm{~cm}$ alt. Caule cilíndrico, densamente pubescente, sem glândulas. Folhas pecioladas, alternas, lâminas $25-57 \times 3-10 \mathrm{~mm}$, papiráceas, pubérulas, sem glândulas, elípticas a estreito-lanceoladas, ápice agudo, base atenuada ou aguda, margem revoluta, ciliada; pecíolos $2 \mathrm{~mm}$ compr. Brácteas e bractéolas decíduas, margem ciliada. Racemos pedunculados, terminais, cilíndricos, 4-8 cm compr., laxifloros. Flores 4-4,2 mm compr., lilases; pedicelos 2-3 mm compr., pilosos, reflexos na frutificação. Sépalas externas glabras, sem glândulas, ápice agudo, margem com tricomas glandulares; uma sépala ovado-côncava, $2 \mathrm{~mm}$ compr.; duas sépalas iguais e concrescidas entre si, ovadas, 1,5-1,8 mm compr.; sépalas internas glabras, sem glândulas, obovadas, 3,2-4,1 mm compr., ápice arredondado, base atenuada. Pétalas laterais desenvolvidas, pilosas internamente, na base, sem glândulas, elíptico-assimétricas, 3-4,5 mm compr., com ápice arredondado; pétalas laterais rudimentares, lineares, $0,3 \mathrm{~mm}$ compr.; carena trilobada, lobo central cuculado, laterais plicado-pregueados, 4-4,2 $\mathrm{mm}$ compr., fortemente unguiculada, sem glândulas, glabra. Ovário glabro, sem glândulas, elíptico, ausência de disco na base. Cápsulas glabras, sem glândulas, oblongas, 3,5-3,8 mm compr., não estipitadas, não aladas. Sementes oblongas, 3-3,2 mm compr., densamente pubescentes, adpresso-seríceas, tricomas prateados, ultrapassando o comprimento da semente, carúncula córnea, $1 \mathrm{~mm}$ compr., com um apêndice dorsal e dois laterais. 
Material examinado: BRASIL. Parané: Jundiaí do Sul, Fazenda Monte Verde, 5-I-2006, J. Carneiro 1606 (MBM); idem, Mata do Cruzeiro, 3-I-2003, J. Carneiro 1399 (MBM).

Polygala violacea tem ampla distribução ocorrendo no México, Cuba, Venezuela, Guiana Francesa, Guiana, Equador, Bolívia, Argentina, Paraguai e Brasil: Amapá, Pará, Maranhão, Piaú, Ceará, Rio Grande do Norte, Paraíba, Pernambuco, Alagoas, Acre, Bahia, Mato Grosso, Espírito Santo, Mato Grosso do Sul, Minas Gerais, Rio de Janeiro, São Paulo, Distrito Federal e Paraná (Bernardi 2000, Marques \& Gomes 2002, Aguiar et al. 2008). Pode ser encontrada em orlas de matas, ambientes ruderais, perturbados (Marques \& Gomes 2002). Floresce e frutifica de outubro a abril (Aguiar et al. 2008).

Como anteriormente discutido, Polygala violacea assemelha-se à $P$. extraaxillaris em várias características, contudo, a separação destes dois táxons pode ser mantida por caracteres observados nas flores, uma vez que em $P$. violacea as mesmas são mais delicadas, menores, alcançando 4-4,2 mm de comprimento. Em P. extraaxillaris as flores apresentam-se maiores, com 5-7 mm de comprimento e coriáceas. Outra característica diagnóstica importante são as cápsulas, que em $P$. extraaxillaris são aladas e estipitadas, enquanto que em $P$. violacea as cápsulas são desprovidas de alas e de estípite.

Pela primeira vez Polygala violacea está sendo referida para a região Sul do Brasil embora apenas dois exemplares tenham sido analisados durante este estudo.

2. Polygala L. subgênero Ligustrina (Chodat) Paiva, Fontqueria 50: 147. 1998.

Espécie tipo: Polygala ligustroides A. St.-Hil., Fl. Bras. Mer. 2: 49. 1829.

Ervas, subarbustos a arbustos. Folhas com um par de nectários extraflorais cilíndricos, na base do pecíolo. Flores reunidas em racemos simples, terminais, axilares, extra-axilares ou opositifólios; pedicelos com um par de nectários extraflorais cilíndricos, na base. Cálice pentâmero, persistente no fruto; sépalas externas abaxiais livres entre si. Corola pentâmera; carena unguiculada, ápice não cristado, cuculado, trilobado; pétalas laterais rudimentares presentes, aderidas ao dorso da bainha estaminal. Gineceu com ovário circundado na base por um disco; estilete geniculado terminando em uma cavidade pré-estigmática infundibuliforme. Sementes subtriangulares, sem tricomas seríceos, carúncula prolongada em um apêndice livre, carnoso, sem apêndices córneos.

O subgênero Ligustrina é restrito à América do Sul, ocorrendo nas Guianas, Peru, Venezuela, Bolívia e Brasil: do Acre até Santa Catarina. Para o Brasil, foram confirmadas 11 espécies e sete variedades (Marques \& Peixoto 2007), destas apenas duas espécies ocorrem na região Sul do Brasil.

Chave para a identificação das espécies de Polygala subg. Ligustrina para a região Sul do Brasil

1. Folhas papiráceas; margem das sépalas internas glabra; pétalas laterais desenvolvidas, pilosas internamente 1.P. insignis

1. Folhas membranáceas; margem das sépalas internas ciliada; pétalas laterais desenvolvidas, glabras 2. P. laureola

2.1. Polygala insignis Klotzsch ex Chodat, Mém. Soc. Phys. \& Hist. Nat. Genève 31: 86. 1893.

Figura 3a-f

Subarbustos a arbustos eretos, $19-50 \mathrm{~cm}$ alt. Caule folioso, cilíndrico, estriado, pubescente, sem glândulas. Folhas pecioladas, alternas, elípticas, lâminas 15-80 × 4-12 mm, papiráceas, pubérulas, sem glândulas, ápice acuminado, mucronado ou cuspidado, base atenuada ou cuneada, margem revoluta, ciliada; pecíolos 2,5-3,5 mm compr., estes com um par de nectários extraflorais estipitados, cilíndricos, 0,5-2 $\mathrm{mm}$ compr. Brácteas e bractéolas tardiamente decíduas, margem densamente ciliada. Racemos pedunculados, terminais e axilares, cilíndricos, 1-6 cm compr., densifloros. Flores 9-11 mm compr., brancas, creme-esverdeadas; pedicelos 3-4 mm compr., pubérulos, reflexos na frutificação, com um par de nectários extraflorais. Sépalas externas glabras, sem glândulas, ápice arredondado, margem densamente ciliada; uma sépala largo-ovada, côncava, 2,7-3,1 mm compr.; duas sépalas livres e iguais entre si, ovadas a largo-ovadas, $2 \mathrm{~mm}$ compr.; sépalas internas glabras, sem glândulas, largo-elípticas a suborbiculares, 6-8 mm compr., ápice arredondado, base obtusa. Pétalas laterais desenvolvidas, pilosas internamente na base, sem glândulas, elípticas, 9-10 mm compr., com ápice arredondado; pétalas laterais rudimentares, estreito-oblongas, 4-5 mm compr.; carena trilobada, cuculada, 8,5-10,5 mm compr., fortemente 

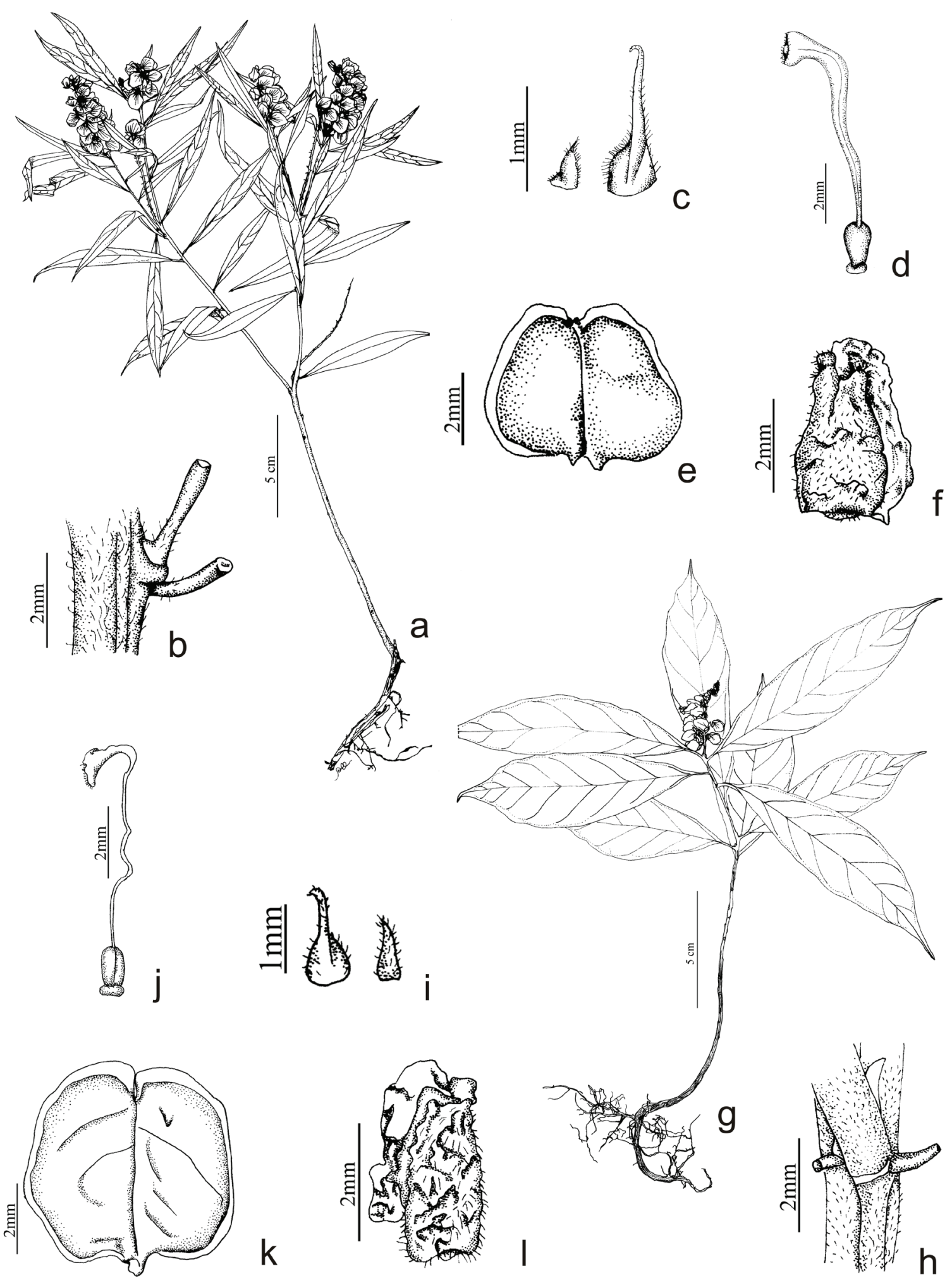

Figura 3. a-f. Polygala insignis. a. Hábito. b. Nectários extraflorais. c. Bractéola e bráctea. d. Gineceu. e. Fruto. f. Semente. g-1. Polygala laureola. g. Hábito. h. Nectários extraflorais. i. Bráctea e bractéola. j. Gineceu. k. Fruto. 1. Semente. [a: Cordeiro \& Cruz 1415 (MBM); b-f: Ribas et al. 4425 (MBM); g-l: Lüdtke 507 (ICN)].

Figure 3. a-f. Polygala insignis. a. Habit. b. Extrafloral nectaries. c. Bracteole and bract. d. Gynoecium. e. Fruit. f. Seed. g-1. Polygala laureola. g. Habit. h. Extrafloral nectaries. i. Bract and bracteole. j. Gynoecium. k. Fruit. 1. Seed. [a: Cordeiro \& Cruz 1415 (MBM); b-f: Ribas et al. 4425 (MBM); g-1: Lüdtke 507 (ICN)]. 
unguiculada, sem glândulas. Ovário glabro, sem glândulas, elíptico. Cápsulas glabras, sem glândulas, oblatas, orbiculares, 5-6 mm compr., levemente estipitadas, aladas, emarginadas nos dois bordos. Sementes estrigosas, subtriangulares, tetragonais, 3,5-4,5 mm compr., superfície verrucosa, carúncula com apêndice carnoso, enrugado, com tricomas esparsos, alcançando o comprimento da semente.

Material examinado: BRASIL. PARANÁ: Guaratuba, Serra do Araçatuba, 10-III-1959, G. Hatschbach 5551 (MBM); idem, 19-XI-1971, G. Hatschbach 28107 (MBM); idem, 21-I-1994, R. Kummrow et al. 3382 (MBM); idem, 9-IX-1994, C.B. Poliquesi \& J. Cordeiro 224 (MBM); idem, 27-II-2000, J.M. Silva et al. 3252 (MBM); idem, 23-II-2002, O.S. Ribas et al. 4425 (MBM); idem, Morro dos Perdidos, 10-XII-1998, E.P. Santos et al. 699 (UPCB); idem, 5-III-1999, E.P. Santos et al. 767 (UPCB); idem, 12-II-2003, E.P. Santos \& A.C. Cervi 1126 (UPCB); idem, 30-III-2007, E.P. Santos \& M.L. Brotto 1181 (UPCB); Piraquara, Morro Anhangava, 8-IV-1951, G. Hatschbach 2215 (MBM); Quatro Barras, Serra de Baitaca, 13-III-1997, J. Cordeiro \& J.M. Cruz 1415 (MBM, PEL).

Polygala insignis ocorre no Brasil: Piauí, Bahia, Minas Gerais, Rio de Janeiro, São Paulo e Paraná (Marques \& Gomes 2002, Marques \& Peixoto 2007). Pode ser encontrada em campos de altitude, associada às zonas de matas e também em interior de matas higrófilas. Floresce e frutifica de setembro a abril. No Estado do Paraná, esta espécie ocorre na Floresta Ombrófila Densa Altomontana, a partir de $1.000 \mathrm{~m}$ de altitude.

Polygala insignis é caracterizada por apresentar brácteas e bractéolas tardiamente decíduas, folhas papiráceas, sépalas internas com margem glabra, pétalas laterais desenvolvidas, pilosas internamente. Assemelha-se à $P$. laureola, mas nesta espécie as brácteas e bractéolas são cedo-decíduas, as folhas membranáceas, as sépalas internas têm margem ciliada e as pétalas laterais são desenvolvidas e glabras.

\subsection{Polygala laureola A. St.-Hil. \& Moq., Mém. Hist}

Nat. Paris 17: 341. 1828.

Figura 3g-1

Subarbustos a arbustos eretos, $30-75 \mathrm{~cm}$ alt. Caule cilíndrico, densamente pubescente, sem glândulas. Folhas pecioladas, alternas, estreito-elípticas a largo-elípticas, obovadas, algumas lâminas onduladas na metade superior, 30-160 × 10-65 mm, membranáceas, pubescentes, sem glândulas, ápice longo-acuminado, agudo ou cuspidado, ocasionalmente lobado, neste caso, ápice dos lobos aristados, base assimétrica, aguda ou cuneada, margem revoluta, ciliada; pecíolos 3-7 mm compr., estes com um par de nectários extraflorais, estipitados, cilíndricos, 1-2 mm compr. Brácteas e bractéolas decíduas, margem ciliada. Racemos pedunculados, terminais ou opositifólios, cilíndricos, 2-10,5 cm compr., densifloros. Flores 8,1-13,5 mm compr., brancas com ápice da carena amarelado ou creme-esverdeadas; pedicelos 3-7,5 mm compr., pubescentes, reflexos ou patentes na frutificação, com um par de nectários extraflorais. Sépalas externas pubescentes no dorso, sem glândulas, ápice obtuso, margem densamente ciliada; uma sépala largo-ovada, côncava, 1,5-5 mm compr.; duas sépalas livres e iguais entre si, oblatas, 1,3-3 mm compr.; sépalas internas ciliadas na margem, sem glândulas, largo-ovadas a suborbiculares, 6-10 mm compr., ápice arredondado, base cuneada. Pétalas laterais desenvolvidas, glabras, sem glândulas, estreito-oblongas a lineares, 7,5-13 mm compr., com ápice arredondado, ondulado ou plicado; pétalas laterais rudimentares, estreito-oblongas, 5-6 mm compr.; carena trilobada, lobo central cuculado, laterais plicados, 8-10,5 mm compr., fortemente unguiculada, sem glândulas. Ovário glabro, sem glândulas, oblongo. Cápsulas glabras, sem glândulas, largo-oblongas, 5,5-7,2 mm compr., levemente estipitadas, aladas, emarginadas nos dois bordos. Sementes pubescentes, subtriangulares, tetragonais, 4-5,5 mm compr., superfície verrucosa, carúncula com apêndice carnoso, enrugado, com tricomas esparsos, alcançando $1 / 2$ a $2 / 3$ ou $o$ comprimento total da semente.

Material selecionado: BRASIL. Paraná: Antonina, 20-II-1965, Y. Saito \& N. Kunyioshi 46 (MBM); Guaraqueçaba, Salto Morato, $25^{\circ} 16^{\prime} \mathrm{S}, 48^{\circ} 19^{\prime} \mathrm{W}$, 4-XII-1997, A.C. Cervi \& O. Guimarães 6469 (FUEL, NY, UPCB); Guaratuba, Rio São João, Porto Miranda, 26-II-1968, G. Hatschbach 18639 (MBM); Ipiranga, 24-IV-1904, P. Dusén 4475 (S); Morretes, Porto de Cima, em direção a Usina Hidroelétrica Marumbi, em frente ao Santuário Nhundiaquara, 25'25'20,3"S, 48 53'02,9"W, 24-II-2006, R. Lüdtke 543 (ICN); Paranaguá, Ilha das Cobras, 16-III-1986, S.M. Silva s.n. (MBM111148, UEC68914). SANTA Catarina: Garuva, estrada para Guaratuba, km 12, 2600'57,5"S, 4844'49,3"W, 8-I-2007, R. Lüdtke 704 (ICN); idem, Porto Palmital, a 5 km da SC 412, próximo a Pousada do Nereu, 26 $06^{\circ} 24,7^{\prime \prime} \mathrm{S}$, 
48 49'09,5"W, 12-I-2006, R. Lüdtke 506 (ICN); Guaramirim, 16-XII-1949, D. Haus 292 (RB); Itajaí, Cunhas, 23-IX-1954, R. Reitz \& R. Klein 2096 (HBR, NY); Joinville, Castelo dos Bugres, 26-X-2004, F.C.S. Vieira 555 (FUEL, JOIN); Rancho Queimado (São José), Serra da Boa Vista, 2-II-1953, R. Reitz 5441 (HBR, NY, S).

Polygala laureola ocorre no Brasil: Bahia, Minas Gerais, Espírito Santo, Rio de Janeiro, São Paulo, Paraná e Santa Catarina (Wurdack \& Smith 1971, Bernardi 2000, Marques \& Gomes 2002, Marques $\&$ Peixoto 2007), podendo ser encontrada na Mata Atlântica, no interior ou borda de matas, em capoeiras, matas pluviais e florestas de restinga. Floresce e frutifica em todos os meses do ano.

Como anteriormente discutido, Polygala laureola pode ser confundida com $P$. insignis, mas as diferenças entre elas foram discutidas nas observações referentes a esta última espécie. Deve-se acrescentar que P. laureola é exclusiva de Mata Atlântica, ocorrendo em Floresta Ombrófila Densa Montana, até $800 \mathrm{~m}$ de altitude.
3. Polygala L. subgênero Polygala, Sp. Pl. 1: 701. 1753.

Espécie tipo: Polygala vulgaris L., Sp. Pl. 1: 701. 1753.

Ervas a subarbustos. Nectários extraflorais ausentes na base do pecíolo e do pedicelo. Flores em racemos terminais ou axilares. Cálice pentâmero, persistente no fruto; sépalas externas abaxiais livres entre si. Corola trímera; carena cristada, pétalas laterais rudimentares ausentes. Ovário desprovido de disco; estilete terminado em duas regiões estigmáticas; uma porção superior estéril com um tufo de tricomas no ápice e a porção mediana formada por uma cavidade e a porção inferior globosa, fértil. Sementes com carúncula córnea pequena, com ou sem apêndice membranáceo bilobado.

Dentre os subgêneros de Polygala, este é o que concentra o maior número de espécies. Segundo Marques (1979) são 88 espécies e 22 variedades para o Brasil. É um subgênero cosmopolita, estando ausente na Nova Zelândia e no Ártico (Paiva 1998).

Chave para a identificação das espécies de Polygala subg. Polygala para a região Sul do Brasil

1. Plantas com folhas predominantemente verticiladas, raro alternas no mesmo indivíduo

2. Plantas desprovidas de glândulas nas folhas, flores e/ou frutos 12. P. glochidiata

2.Plantas com glândulas nas folhas, flores e/ou frutos

3. Flores rosadas, lilases ou magenta; com brácteas e bractéolas decíduas 18. P. molluginifolia

3. Flores brancas ou branco-esverdeadas; com brácteas e bractéolas persistentes 1. P. adenophylla

1. Plantas com folhas predominantemente alternas, opostas, raro subverticiladas

4. Plantas com folhas sésseis

5. Plantas subáfilas ou com folhas escamiformes

6. Plantas com glândulas no caule, folhas, flores e/ou frutos; sementes sem apêndice membranáceo ...... 30. P. tenuis

6. Plantas sem glândulas no caule, folhas, flores e/ou frutos; sementes com apêndice membranáceo desenvolvido 3. P. aphylla

5. Plantas com folhas desenvolvidas

7. Racemos sésseis ou subsésseis

8. Folhas glandulosas, obovadas, elípticas ou oblongas 28. P. subverticillata

8. Folhas não glandulosas, filiformes ou estreito-lineares

9. Folhas papiráceas; brácteas e bractéolas tardiamente decíduas; flores brancas a branco-esverdeadas, creme; nunca encontrada em dunas litorâneas 4. P. aspalatha

9. Folhas carnosas; brácteas e bractéolas decíduas; flores brancas com manchas roxas; exclusiva de dunas litorâneas 9. P. cyparissias

\section{Racemos pedunculados}

10. Folhas carnosas; caules com ramificação mediana umbeliforme 26. P. sabulosa

10. Folhas membranáceas, papiráceas ou cartáceas; caules sem ramificação mediana umbeliforme

11. Cápsulas aladas 
12. Sementes glabras

7. P. brasiliensis

12. Sementes pilosas

13. Racemos capitados ou curto-cilíndricos

16. P. longicaulis

13. Racemos cilíndricos ou estreito-cilíndricos

14. Folhas imbricadas; racemos densifloros; sementes reniformes

27. P. selaginoides

14. Folhas não imbricadas; racemos laxifloros; sementes não reniformes, retas

15. Subarbustos decumbentes ou cespitosos; caules muito ramificados e densamente foliosos

6. P. bonariensis

15. Subarbustos eretos; caules simples ou pouco ramificados e esparsamente foliosos

11. P. duarteana

11. Cápsulas não aladas

16. Plantas densamente foliosas; folhas adpressas ao caule

17. Racemos curto-cilíndricos a globosos; folhas 2-9 $\times 0,5-1 \mathrm{~mm}$

17.P. lycopodyoides

17. Racemos cilíndricos a piramidais; $5-13 \times 1-3,5 \mathrm{~mm}$ 29. P. telephium

16. Plantas esparsamente foliosas; folhas nunca adpressas ao caule

18. Folhas pouco desenvolvidas, escamiformes; cápsulas uni ou bisseminadas

19. P. monosperma

18. Folhas desenvolvidas, cápsulas sempre bisseminadas

19. Plantas com glândulas no caule, folhas, flores e/ou frutos

20. Racemos laxifloros, estreito-cilíndricos; cápsulas sem glândulas .........P. paniculata

20. Racemos densifloros e largo-cilíndricos; cápsulas com glândulas ..... 31. P. timoutoides

19. Plantas sem glândulas no caule, folhas, flores e/ou frutos

21. Sementes com coroa de tricomas rígidos na base

5. P. australis

21. Sementes sem coroa de tricomas rígidos na base

22. Plantas cespitosas ou decumbentes; racemos densifloros .... 11.P. densiracemosa 22. Plantas eretas a prostradas; racemos laxifloros a subdensifloros

23. Flores brancas ou branco-esverdeadas; carena dividida em 4-6 lobos simples 23. P. pulchella

23. Flores rosadas, lilases, roxas ou azuis; carena dividida em 6-12 lobos simples ou bífidos

24. Brácteas com margem ciliada; sementes pubescentes .... 8. P. campestris

24. Brácteas com margem lisa; sementes pubérulas 15. P. linoides

4. Plantas com folhas pecioladas

25. Racemos capitados a curto-cilíndricos

26. Folhas predominantemente opostas

27. Folhas carnosas; racemos curto-pedunculados; flores predominantemente brancas; estigma e estilete persistentes no fruto

2. P. altomontana

27. Folhas cartáceas; racemos longo-pedunculados (até $38 \mathrm{~mm}$ compr.); flores rosadas ou magenta; estigma e estilete decíduos no fruto

20. P. moquiniana

26. Folhas alternas

21. P. obovata

25. Racemos cilíndricos

28. Plantas com glândulas nas folhas; flores e/ou frutos

29. Ervas decumbentes, $3,5-5 \mathrm{~cm}$ alt.; semente com apêndice membranáceo bilobado atingindo $3 / 4$ ou o comprimento total da semente

24. P. pumila

29. Subarbustos eretos, 9,3-61 cm alt.; semente com apêndice membranáceo bilobado

atingindo $1 / 10$ do comprimento da semente

14. P. leptocaulis

28. Plantas sem glândulas nas folhas; flores e/ou frutos

30. Ervas decumbentes a prostradas, $11-34 \mathrm{~cm}$ alt.; caules sinuosos 25. P. riograndensis

30. Subarbustos eretos e apoiantes, $20-156 \mathrm{~cm}$ alt.; caules nunca sinuosos 13. P. lancifolia 
3.1. Polygala adenophylla A. St.-Hil. \& Moq., Mém. Mus. Hist. Nat. 17: 369. 1828.

Figura 4a-d

Ervas eretas a decumbentes, $6-40 \mathrm{~cm}$ alt. Caule folioso, quadrangular ou cilíndrico, fortemente estriado, glabro, sem glândulas, com ramificação basal, mediana ou terminal. Folhas sésseis, $4-5$ verticiladas na base e alternas no ápice da planta, ou verticiladas na base e opostas no ápice da planta, papiráceas, glabras, glandulosas, obovadas, largo-obovadas, estreito-elípticas a largo-elípticas ou oblongas, lâminas 5-34 × 1-12 mm, ápice agudo, apiculado, acuminado, cuspidado ou caudado, base atenuada, margem irregular, lisa. Brácteas e bractéolas persistentes, margem ciliada. Racemos pedunculados, terminais, cilíndricos ou largo-cilíndricos, 1-12,5 cm compr., densifloros. Flores 3,2-4,5 mm compr., brancas ou branco-esverdeadas; pedicelos 0,7-2 mm compr., glabros, eretos na frutificação. Sépalas externas glabras, glandulosas, ápice obtuso ou agudo, margem ciliada; uma sépala ovada ou lanceolada, 1,5-2,8 mm compr.; duas sépalas livres e iguais entre si, ovadas ou lanceoladas, 1-2,4 mm compr.; sépalas internas glabras, glandulosas, elípticas, 3,2-4,5 mm compr., ápice obtuso, base atenuada. Pétalas laterais glabras, glandulosas, elípticas ou rômbicas, 2,5-4 mm compr., ápice obtuso; carena cristada, glandulosas no dorso, crista 1,5-2 mm compr., com 8-10 lobos simples. Ovário glabro, glanduloso, oblongo. Cápsulas glabras, glandulosas, oblongas, 2-3 mm compr., não estipitadas, não aladas. Sementes pubescentes, elipsoides ou ovoides, 1,3-2 mm compr., com um apêndice membranáceo profundamente bilobado, atingindo de $3 / 4$ ou o comprimento total da semente.

Material selecionado: BRASIL. PARANÁ: Jaguaraíva, campo $5 \mathrm{~km}$ de Jaguaraíva, 17-X-1966, J.C. Lindeman \& J.H. Haas 3107 (U); Laranjeira do Sul, 7-XI-1963, E. Pereira \& G. Hatschbach 7747 (MBM); Tibagi, Fazenda Monte Alegre, Harmonia, 13-IX-1952, G. Hatschbach 2784 (MBM). Rio Grande Do Sul: Caçapava do Sul, na estrada para as Minas do Camaquã (indo por Guarda Velha), 30 $47^{\prime} 30,0^{\prime \prime} \mathrm{S}, 53^{\circ} 25^{\prime} 41,2^{\prime \prime} \mathrm{W}$, 2-V-2006, R. Lüdtke 574 (ICN); Canguçú, estrada para a barca, 30 $0^{\circ} 4^{\prime} 37,6^{\prime \prime} \mathrm{S}, 52^{\circ} 14^{\prime} 41,0^{\prime \prime} \mathrm{W}, 1-\mathrm{V}-2006$, R. Lüdtke 569 (ICN); Giruá, Granja Sodol, 20-X-1962, K. Hagelund 465 (ICN); Herval, RS 608, para Pinheiro Machado, 31 53 '31,2"S, 53²9'33,2"W, 31-X-2006, R. Lüdtke 641 (ICN); Lavras do Sul, Mina Volta Grande, IX-1984, M. Sobral 3124 (ICN); Passo Fundo, no km 11 da rodovia para Porto Alegre, 14-XI-1978, J. Mattos 20516 (HAS); Porto
Alegre, Morro da Polícia, X-1944, B. Rambo 27033 (PACA); Rio Grande, perto de Quinta, 8-XI-1901, G.A. Malme 297 (S); Santa Rosa, 20 km SE de Santa Rosa, 2-XI-1971, J.C. Lindeman \& B.E. Irgang s.n. (HAS5628); São Luiz Gonzaga, BR 287, 13 km de Santiago, 20-XI-2002, R. Lüdtke 58 (ICN).

Polygala adenophylla ocorre na Argentina, Paraguai, Uruguai e Brasil. No Brasil é restrita à região Sul do Brasil, sendo encontrada apenas nos Estados do Paraná e Rio Grande do Sul. Trabalhos anteriores realizados com a família Polygalaceae (Wurdack \& Smith 1971, Marques 1979) não citaram P. adenophylla para o Estado de Santa Catarina, e durante a realização deste trabalho também não foram encontrados registros desta espécie para o Estado. Essa situação pode ser explicada por uma possível carência de esforço de coletas ou pela atual alteração dos ambientes. Os poucos exemplares de $P$. adenophylla coletados no Paraná são datados das décadas de 1950 e 1960 e não há registros de coletas atuais, enquanto que no Rio Grande do Sul esta espécie é de distribuição ampla e pode ser facilmente encontrada nos mais diversos ambientes. A inexistência de coletas em Santa Catarina e os escassos e antigos registros para o Paraná podem sugerir que este táxon não ocorra mais nestes Estados, ficando restrito ao extremo Sul do Brasil e países vizinhos. Pode ser encontrada em campos rupestres, arbustivos ou graminosos, beira de estradas, topos de morros graníticos, em solos pedregosos, secos ou úmidos. Floresce e frutifica em todos os meses do ano.

Alguns exemplares de Polygala adenophylla foram coletados com xilopódio, indicando uma alteração severa do hábitat, especialmente devido ao uso do fogo nas beiras das estradas.

A filotaxia verticilada característica de Polygala adenophylla é compartilhada com $P$. molluginifolia e $P$. glochidiata, porém apenas em $P$. adenophylla as brácteas e bractéolas são persistentes e as flores são brancas a branco-esverdeadas, ao contrário de P. molluginifolia na qual as flores são sempre rosadas a magenta. A presença de folhas pecioladas e a ausência de glândulas nas folhas e nas estruturas reprodutivas em $P$. glochidiata a diferencia das outras duas espécies acima citadas.

3.2. Polygala altomontana Lüdtke, Boldrini \& Miotto, Kew Bull. 63: 665. 2008.

Figura 4e-g

Subarbustos prostrados, $16-47 \mathrm{~cm}$ alt. Caule folioso, quadrangular, glabro, glanduloso, com 


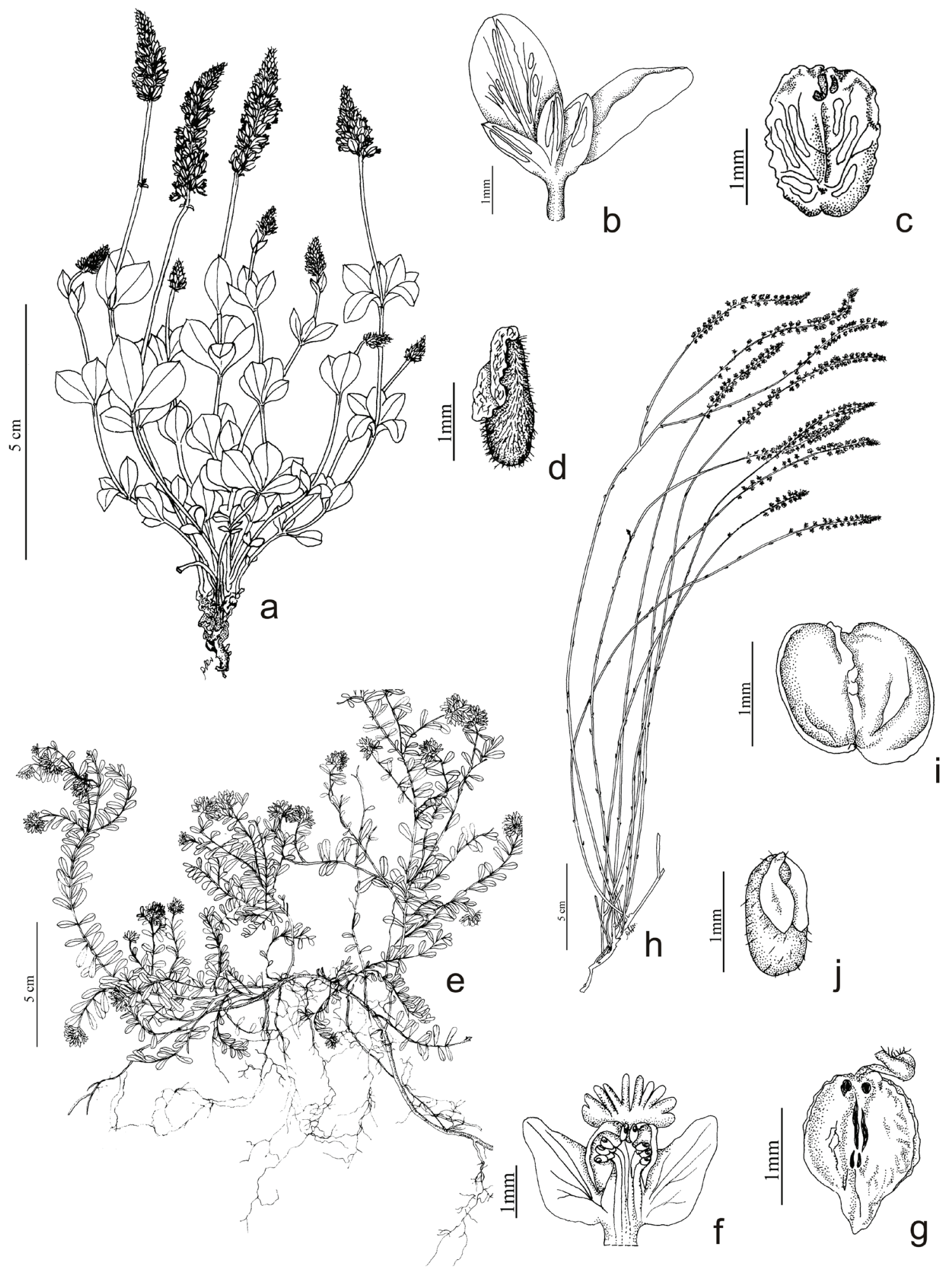

Figura 4. a-d. Polygala adenophylla. a. Hábito. b. Cálice. c. Fruto. d. Semente. e-g. Polygala altomontana. e. Hábito. f. Corola e androceu em secção longitudinal. g. Fruto. h-j. Polygala aphylla. h. Hábito. i. Fruto. j. Semente. [a: Malme 242 (S); b-d: Lüdtke 138 (ICN); e-g: Lüdtke 497 (ICN); h: Lüdtke 46 (ICN); i-j: Jarenkow \& Sobral 781 (PEL)].

Figure 4. a-d. Polygala adenophylla. a. Habit. b. Calyx. c. Fruit. d. Seed. e-g. Polygala altomontana. e. Habit. f. Corolla and androecium in longitudinal section. g. Fruit. h-j. Polygala aphylla. h. Habit. i. Fruit. j. Seed. [a: Malme 242 (S); b-d: Lüdtke 138 (ICN); e-g: Lüdtke 497 (ICN); h: Lüdtke 46 (ICN); i-j: Jarenkow \& Sobral 781 (PEL)]. 
intensa ramificação basal, mediana e terminal. Folhas numerosas, pecioladas, geralmente opostas, raro alternas, patentes, carnosas, glabras, glandulosas, estreito-elípticas a elípticas, obovadas, lâminas 5-12 × 2-5 mm, ápice apiculado ou mucronado, base atenuada, margem inteira, lisa; pecíolos $1 \mathrm{~mm}$ compr. Brácteas e bractéolas tardiamente decíduas, margem lisa. Racemos curto-pedunculados, terminais, capitados, 0,7-2,5 cm compr., densifloros. Flores 2,2-4,0 mm compr., brancas, rosadas ou lilases, pedicelos 2-3 $\mathrm{mm}$ compr., glabros ou pubérulos, patentes a reflexos na frutificação. Sépalas externas glabras, glandulosas, ápice agudo, margem lisa; uma sépala ovada, 1-2 mm compr.; duas sépalas livres e iguais entre si, ovadas, 1-1,8 mm compr.; sépalas internas glabras, sem glândulas, elípticas a largo-elípticas, 2,2-3,8 mm compr., ápice mucronado, base atenuada. Pétalas laterais glabras, sem glândulas, elípticas, 1,8-3 mm compr., ápice arredondado; carena cristada, glandulosa no dorso, crista com 0,5-1,1 mm compr., com 6-8 lobos simples e bífidos. Ovário glabro, glanduloso, largo-elíptico a suborbicular. Cápsulas glabras, glandulosas, largo-elípticas a suborbiculares, 1,8-2,5 mm compr., longo-estipitadas, aladas, curtamente emarginadas nos dois bordos, corola, estilete e estigma persistentes. Sementes pubescentes, elipsoides, 1,2-1,9 mm compr., com apêndice membranáceo totalmente bilobado, atingindo de $3 / 4$ ou o comprimento total da semente.

Material selecionado: BRASIL. ParanÁ: Campina Grande do Sul, Pico Camaquã, 29-IV-1970, G. Hatschbach 24217 (MBM); Jaguariaíva, Sertão de Areia, 18-XI-1970, G. Hatschbach \& O. Guimarães 25474 (UEC); idem, Fazenda Cajurú, 13-X-1968, G. Hatschbach 20069 (MBM, NY); SANTA CATARINA: Campo Alegre, Serra do Quiriri, 29-IX-2001, O.S. Ribas et al. 3647 (MBM); Urubici, Pericó, 2809'37,6"S, 49³7'09,7"W, 15-XII-2004, I. Boldrini \& L. Eggers 1371 (ICN); idem, subida para o Campo dos Padres, 27 $7^{\circ} 9^{\prime} 04,2^{\prime \prime} \mathrm{S}, 4^{\circ} 28^{\prime} 06,3^{\prime \prime} \mathrm{W}, 10-\mathrm{I}-2006$, R. Lüdtke 497 (ICN).

Até o momento esta espécie foi encontrada somente no sul do Brasil, nos Estados do Paraná e de Santa Catarina, sendo exclusiva de campos de altitude (900-1.700 m de altitude). Pode ser encontrada em campos rochosos, beira de banhados, beira de estradas, em organossolos ou solos úmidos. Floresce e frutifica de julho a abril.

Pode ser confundida com Polygala sabulosa, especialmente por ambas apresentarem glândulas nas folhas, brácteas, sépalas externas e frutos, e também por apresentarem folhas carnosas e flores reunidas em racemos capitados. Entretanto, Polygala altomontana se diferencia de $P$. sabulosa por apresentar hábito prostrado, com intensa ramificação, folhas elípticas a obovadas, opostas, raramente alternas, flores brancas a rosadas, corola persistente na frutificação, cápsulas aladas, além de estilete e estigma persistentes no fruto. Polygala sabulosa é um subarbusto ereto, com ramificação terminal umbeliforme, folhas alternas, elípticas, aciculadas, flores rosadas ou liláses, cápsulas desprovidas de alas, corola, estilete e estigma caducos na frutificação.

3.3. Polygala aphylla A.W. Benn., Fl. Bras. 13(3): 21. 1874.

Figura 4h-j

Ervas e subarbustos eretos, decumbentes ou subarbustos apoiantes, $18-72 \mathrm{~cm}$ alt. Caule subáfilo, cilíndrico, fortemente estriado ou subanguloso, glabro, sem glândulas, com ramificação basal, mediana ou terminal. Folhas sésseis, alternas, papiráceas, glabras, sem glândulas, lanceoladas a largo-lanceoladas, escamiformes (adpressas ao caule) ou triangulares, lâminas 1,3-2,1 ×0,3-0,7 mm, ápice acuminado, margem lisa ou inteira, ciliada. Brácteas e bractéolas decíduas, margem lisa ou ciliada. Racemos pedunculados, terminais, cilíndricos, 1-20,5 cm compr., laxifloros. Flores 2,1-3,1 mm compr., brancas a rosadas ou branco-esverdeadas; pedicelos 0,3-1 mm compr., glabros, eretos, patentes ou reflexos na frutificação. Sépalas externas glabras, sem glândulas, ápice obtuso ou agudo, margem inteira; uma sépala largo-ovada, 1,5-2,1 mm compr.; duas sépalas livres e iguais entre si, ovadas, 1,1-2 mm compr.; sépalas internas glabras, sem glândulas, estreito-espatuladas, 2-3 mm compr., ápice obtuso ou arredondado, base atenuada. Pétalas laterais glabras, sem glândulas, elíptico-assimétricas, 1,7-3 mm compr., ápice obtuso; carena cristada, sem glândulas, crista 0,5-1 mm compr., com 6-8 lobos simples e bífidos. Ovário glabro, sem glândulas, elíptico, oblongo ou orbicular. Cápsulas glabras, sem glândulas, orbiculares ou oblongas, 1,3-2,5 mm compr., não estipitadas, aladas, emarginadas nos dois bordos. Sementes esparsamente pubérulas ou pubescentes, oblongas ou elipsoides, 1-2 mm compr., com apêndice membranáceo profundamente bilobado, atingindo de $3 / 4$ ao comprimento total da semente.

Material selecionado: BRASIL. PARANÁ: Bocaiúva do Sul, Localidade de Capivari, 16-X-1949, 
G. Hatschbach 1541 (MBM); Rio Branco do Sul, Serra do Caeté, 24-VII-1980, G. Hatschbach 43041 (MBM). Rio Grande do Sul: Cachoeira do Sul, BR 290, km 265, 29-XI-2002, R. Lüdtke 46 (ICN); Campestre da Serra, BR 116, km 74, 28 45'19,3"S, $51^{\circ} 05^{\prime} 39,7^{\prime \prime} \mathrm{W}, 5-\mathrm{XI}-2007$, R. Lüdtke 771 (ICN); Cristal, estrada para Amaral Ferrador, a $10 \mathrm{~km}$ da BR 116, 30 55'23,4"S, 52 03'39,4"W, 1-V-2006, R. Lüdtke 567 (ICN); Lagoa Vermelha, na encruzilhada para Tapejara, km 107, 14-XI-1978, J. Mattos 20463 (HAS); Lavras do Sul, Mina Volta Grande, IX-1984, M. Sobral s.n. (ICN 80374); Santo Ângelo, Granja Piratini, 1969, K. Hagelund 5622 (ICN); São José dos Ausentes, Pico do Montenegro, 14-I-2001, S.T.S. Miotto 1930 (ICN); Uruguaiana, BR 290, km 213, I-1972, A. Pott 32 (BLA). Santa Catarina: Bom Jardim da Serra, SC 438, no final da subida da Serra do Rio do Rastro, 28 24'03, 7"S, 49³3'04,4"W, 9-I-2006, R. Lüdtke 492 (ICN); Bom Retiro, Campo dos Padres, 23-I-1957, B. Rambo 60180 (B, PACA); Campo Alegre, Serra do Quiriri, Rio dos Alemães, 28-IV-2001, O.S. Ribas et al. 3553 (MBM); Mafra, 10 km W de Tinguí, 2-II-1957, L.B. Smith \& R. Klein 10615 (NY); Painel, km 35 da rodovia Lages-São Joaquim, 20-X-2004, R. Lüdtke 262 (ICN).

Polygala aphylla ocorre no Brasil: Mato Grosso, Goiás, Minas Gerais, São Paulo, Rio de Janeiro, Paraná, Santa Catarina e Rio Grande do Sul (Angely 1965, Marques 1988, Bernardi 2000, Marques \& Gomes 2002, Lüdtke \& Miotto 2004). Pela primeira vez esta espécie está sendo referida para o Estado do Paraná. Pode ser encontrada em campos graminosos, arbustivos ou pedregosos, de solos secos e úmidos, beiras de estradas, beira de matas, barrancos úmidos, turfeiras e banhados. Floresce e frutifica em todos os meses do ano.

Bernardi (2000) sinonimizou Polygala glaziowii com $P$. aphylla. As descrições das duas espécies (Marques 1979) são de fato semelhantes, porém, não foi possível analisar o exemplar-tipo de $P$. glaziowii, e com isso é prematuro aceitar a sinonimização feita pelo autor. Marques $(1979,1988)$ citou P. glaziowii para os três Estados da região Sul do Brasil, entretanto, verificou-se que o material citado é, na verdade, P. aphylla. Durante a realização deste trabalho não foi coletado ou analisado nenhum material de $P$. glaziowii para a região Sul do Brasil.

Polygala aphylla caracteriza-se pelas folhas diminutas, as vezes ausentes.
3.4. Polygala aspalatha L., Mant. Plant.: 99. 1767. Figura 5a-c

Subarbustos eretos ou decumbentes, $10-70 \mathrm{~cm}$ alt. Caule folioso, cilíndrico, fortemente estriado, glabro, sem glândulas, com ramificação basal, mediana ou terminal. Folhas sésseis, alternas, papiráceas, glabras, sem glândulas, filiformes ou estreito-lineares, lâminas 3-17 × 0,3-1 mm, ápice acuminado, base cuneada, margem lisa. Brácteas e bractéolas tardiamente decíduas, margem lisa. Racemos subsésseis, terminais, capitados ou subcapitados, 0,7-2,5 cm compr., densifloros. Flores 4-5 mm compr., brancas, branco-esverdeadas, creme ou lilases; pedicelos 1-5 mm compr., glabros ou pilosos, eretos na frutificação. Sépalas externas glabras ou pilosas, sem glândulas, ápice acuminado, margem inteira; uma sépala ovada ou ovado-lanceolada, 1-2,2 mm compr.; duas sépalas livres e iguais entre si, lanceoladas ou ovado-lanceoladas, 2,5-4 mm compr.; sépalas internas glabras, sem glândulas, elípticas, 4-5 mm compr., ápice apiculado, base cuneada. Pétalas laterais pilosas internamente ou na parte basal, sem glândulas, elípticas, 2,2-4 mm compr., ápice obtuso; carena cristada, sem glândulas, crista 0,7-1,5 mm compr., com sete lobos simples. Ovário glabro, sem glândulas, suborbicular ou orbicular. Cápsulas glabras, sem glândulas, suborbiculares, 2,2-3 mm compr., não estipitadas, aladas, emarginadas em ambos os bordos. Sementes pubérulas, globosas, 1,8-2 mm compr., com apêndice membranáceo profundamente bilobado, igual ou ultrapassando $0,3 \mathrm{~mm}$ o comprimento da semente.

Material selecionado: BRASIL. ParanÁ: Pien, rodovia para Campinas, 8-XI-1989, G. Hatschbach \& J.M. Silva 53602 (MBM). Rio Grande do Sul: Bom Jesus, Serra da Rocinha, 14-I-1952, B. Rambo 8689 (PACA); Caçapava do Sul, Guaritas, 28-VIII-1998, S.A.L. Bordignon et al. 1435 (HERULBRA); Erechim, 9-VIII-2005, F. Marchett 341 (UCS); Itaara (Santa Maria), Reserva Biológica do Ibicuí-Mirim, 9-XI-1988, O. Bueno 5648 (HAS); Novo Hamburgo, Arroio Divisa, 18-X-1904, A. Bornmüller 260 (GH); Rio Grande, Cassino Sul, navio afundado, 29-X-1981, V. Cordazzo \& V. Seelinger 384 (ICN); Santana do Livramento, Cerro Palomas, 15-X-1971, J.C. Lindeman et al. s.n. (U19000); São Francisco de Paula, Cazuza Ferreira, 21-X-1999, S.A.L. Bordignon et al. 1752 (HERULBRA); Viamão, Granja Neugebauer, 27-IX-1950, B. Rambo 48843 


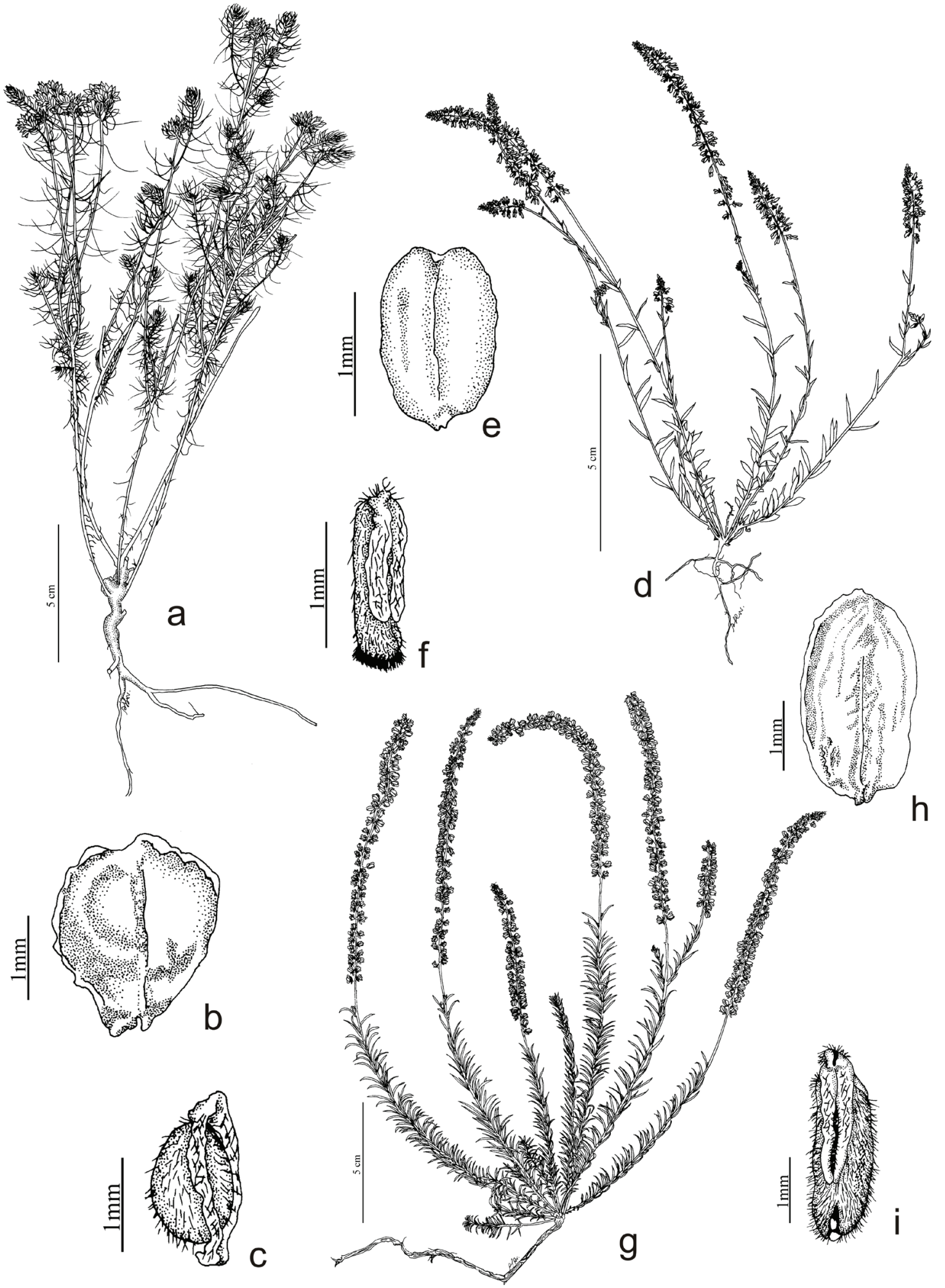

Figura 5. a-c. Polygala aspalatha. a. Hábito. b. Fruto. c. Semente. d-f. Polygala australis. d. Hábito. e. Fruto. f. Semente. g-i. Polygala bonariensis. g. Hábito. h. Fruto. i. Semente. [a: Lindeman et al. s.n. (ICN8541); b-c. Malme 364B (S); d: Mattos 31481 (HAS); e-f: Mattos \& Mattos 23212 (HAS); g: Sacco et al. 2584 (PEL); h-i: Lüdtke 79 (ICN)].

Figure 5. a-c. Polygala aspalatha. a. Habit. b. Fruit. c. Seed. d-f. Polygala australis. d. Habit. e. Fruit. f. Seed. g-i. Polygala bonariensis. g. Habit. h. Fruit. i. Seed. [a: Lindeman et al. s.n. (ICN8541); b-c. Malme 364B (S); d: Mattos 31481 (HAS); e-f: Mattos \& Mattos 23212 (HAS); g: Sacco et al. 2584 (PEL); h-i: Lüdtke 79 (ICN)]. 
(B, NY, PACA). Santa Catarina: Bom Jardim da Serra, Desfiladeiro do Funil, III-1987, M. Sobral et al. 5418 (ICN); Campos Novos, BR 282, km 350, $27^{\circ} 21^{\prime} 30,0^{\prime \prime} \mathrm{S}, 51^{\circ} 19^{\prime} 27,0^{\prime \prime} \mathrm{W}, 10-\mathrm{X}-2006$, R. Lüdtke 590 (ICN); Capinzal, entrada de Capinzal, 30-X-1963, R. Klein 4291 (HBR).

Polygala aspalatha ocorre na Argentina, Paraguai, Uruguai e Brasil: Paraná, Santa Catarina e Rio Grande do Sul (Grondona 1948, Angely 1965, Marques 1988, Bernardi 2000, Lüdtke \& Miotto 2004) podendo ser encontrada em campos pedregosos, arbustivos ou graminosos, beira de estradas, beira de matas e em baixadas úmidas. Floresce e frutifica de julho a março.

Polygala aspalatha assemelha-se muito a $P$. cyparissias, tanto no hábito quanto em detalhes morfológicos peculiares, como a presença de tricomas na parte interna basal das pétalas laterais, além das características das cápsulas e das sementes. Polygala aspalatha difere de P. cyparissias por apresentar folhas mais estreitas e longas com até $17 \times 1 \mathrm{~mm}$ de comprimento, sépalas internas mais longas, com 2,2 mm de comprimento, mas, as vezes, não há como distingui-las morfologicamente por estes caracteres. Polygala aspalatha possui brácteas e bractéolas tardiamente caducas e folhas membranáceas, enquanto que em $P$. cyparissias as brácteas e bractéolas são decíduas e as folhas são carnosas.

3.5. Polygala australis A.W. Benn., Journ. of Bot. 17: 203. 1879.

Figura $5 \mathrm{~d}-\mathrm{f}$

Ervas decumbentes, 3-19 cm alt. Caule folioso, cilíndrico na base e quadrangular no ápice, ou cilíndrico, fortemente estriado, escasso ou densamente piloso, com tricomas curtos, sem glândulas, com ramificação basal, mediana ou terminal. Folhas sésseis, alternas, papiráceas, pilosas, sem glândulas, estreito-lineares, lineares, ovadas, estreito-elípticas ou elípticas, lâminas 3-10 × 0,3-3 mm, ápice mucronado ou acuminado, base atenuada, margem inteira, ciliada. Brácteas e bractéolas decíduas, margem lisa. Racemos pedunculados, terminais, cilíndricos, 1-15 cm compr., laxifloros. Flores 2-3 mm compr., brancas, creme, brancas com manchas rosadas ou com manchas roxas; pedicelos 0,3-1 mm compr., glabros, eretos ou reflexos na frutificação. Sépalas externas glabras, sem glândulas, ápice obtuso ou arredondado, margem inteira; uma sépala ovada, 1-1,2 mm compr.; duas sépalas livres e iguais entre si, ovadas, 1-1,2 mm compr.; sépalas internas glabras, sem glândulas, elípticas ou largo-elípticas, 1,8-2,5 mm compr., ápice agudo, base atenuada. Pétalas laterais glabras, sem glândulas, elípticas, 1,2-2 mm compr., ápice obtuso ou arredondado; carena cristada, sem glândulas, crista 0,3-1 mm compr., com 4-8 lobos simples. Ovário glabro, sem glândulas, elíptico ou elíptico-oblongo. Cápsulas glabras, sem glândulas, largo-oblongas, 1,5-2 mm compr., não estipitadas, não aladas. Sementes escassamente pubescentes, com uma coroa de tricomas rígidos na base, estreito-oblongas, oblongas, elipsoides ou ovoides, 1,2-2 mm compr., com apêndice membranáceo profundamente bilobado, atingindo de $1 / 2$ a $3 / 4$ do comprimento da semente.

Material selecionado: BRASIL. Rio GRANDE do Sul: Bagé, BR 153, sentido Bagé-Caçapava, a 4 km da 38 Cabanha, 23-XI-2002, R. Lüdtke 85 (ICN); Barra do Quaraí, Parque Estadual do Espinilho, 21-IX-2003, V. Kinupp \& B. Irgang 2721a (ICN); Caçapava do Sul, Arroio João Dias, Guaritas, 27-VIII-1998, S.A.L. Bordignon et al. 1433 (HERULBRA); Capão do Leão, BR 116, km 550, 31 ${ }^{\circ} 51^{\prime} 44,0^{\prime \prime} \mathrm{S}, 52^{\circ} 36^{\prime} 04,2^{\prime \prime} \mathrm{W}$, 31-X-2006, R. Lüdtke 615 (ICN); Eldorado do Sul (Guaíba), Estação Experimental Agronômica da UFRGS, 23-IX-1970, L. Arzivenco s.n. (BLA10320); Pompeu Machado, Fazenda Quatro Meninas, Serra das Pedrosas, 10-X-1972, J.C. Lindeman et al. s.n. (ICN 20629); Porto Alegre, Morro da Polícia, 10-X-2003, R. Lüdtke 191 (ICN); Quaraí, início da estrada para o Cerro do Jarau, 4-XI-1995, J.R. Stehmann et al. 2017 (UEC); Santana do Livramento, Cerro Palomas, 15-X-1971, J.C. Lindeman et al. s.n. (ICN8548); São Martinho, N. Silveira 7807 (HAS); Uruguaiana, 1957, Spies s.n. (PACA63231).

Polygala australis ocorre na Argentina, Uruguai e Brasil, no Estado do Rio Grande do Sul (Grondona 1948, Marques 1988, Bernardi 2000, Lüdtke \& Miotto 2004). É encontrada em campos graminosos, arbustivos, locais alterados, de solos secos ou úmidos, em morros graníticos e de arenito, beira de estradas e em baixadas úmidas e floresce e frutifica de agosto a abril.

O hábito e aspecto geral lembram Polygala pulchella, mas $P$. australis difere desta e das demais espécies por apresentar uma coroa de tricomas rígidos na base da semente, que variam em comprimento e densidade.

Bernardi (2000) sinonimizou Polygala australis com $P$. pulchella. Não foi possível observar o typus 
de $P$. australis, mas pela análise de exsicatas e a partir de observações no campo, a sinonimização feita por Bernardi (2000) foi aqui desconsiderada. Polygala australis tem uma semente inconfundível, totalmente diferente da de $P$. pulchella, sendo que para o gênero Polygala a semente é importante caráter taxonômico. No presente estudo, $P$. australis é aceita como espécie válida e independente de $P$. pulchella.

\subsection{Polygala bonariensis Grondona, Darwiniana} 6(1): 104. 1942.

Figura $5 \mathrm{~g}-\mathrm{i}$

Subarbustos eretos, decumbentes ou cespitosos, $7-41,5 \mathrm{~cm}$ alt. Caule densamente folioso, cilíndrico ou levemente estriado, densamente piloso, com tricomas curtos, sem glândulas, com ramificação basal, mediana ou terminal. Folhas sésseis, alternas, papiráceas, pilosas, sem glândulas, estreito-lineares, lineares, estreito-elípticas ou elípticas, lâminas 2-16 × 0,3-1 mm, ápice agudo ou acuminado, base cuneada, margem denticulada. Brácteas e bractéolas decíduas, margem ciliada. Racemos pedunculados, terminais, cilíndricos, 1-21 cm compr., laxifloros. Flores 2,8-3,5 mm compr., brancas, branco-esverdeadas ou brancas com manchas rosadas; pedicelos 0,8-1,2 mm compr., glabros, reflexos na frutificação. Sépalas externas glabras, sem glândulas, ápice agudo, margem levemente denticulada; uma sépala lanceolada ou ovado-lanceolada, 1,8-2,1 mm compr.; duas sépalas livres e iguais entre si, lanceoladas ou ovado-lanceoladas, 1,3-1,8 mm compr.; sépalas internas glabras, sem glândulas, espatuladas ou largo-espatuladas, 2,7-3,2 $\mathrm{mm}$ compr., ápice arredondado, base atenuada. Pétalas laterais glabras, sem glândulas, elípticas, 2-2,8 mm compr., ápice obtuso; carena cristada, sem glândulas, crista 1-1,3 mm compr., com 6-10 lobos simples e bífidos. Ovário glabro, sem glândulas, elíptico ou elíptico-oblongo. Cápsulas glabras, sem glândulas, oblongas, 2,6-3,5 mm compr., não estipitadas, aladas, emarginadas em ambos os bordos. Sementes pubescentes, retas, estreito-elipsoides, 2,1-2,8 $\mathrm{mm}$ compr., com apêndice membranáceo profundamente bilobado, atingindo de $1 / 2$ ao comprimento total da semente.

Material selecionado: BRASIL. Rio GRANDE DO Sul: Aceguá, BR 153, km 473, 31 $31^{\circ} 46,3$ "S, 54 08'21,4"W, 17-XI-2006, I. Boldrini 1457 (ICN); Arroio dos Ratos, Fazenda Faxinal, 16-XI-1983, K. Hagelund 14688 (ICN); Bagé, BR 153, km 628,
23-XI-2002, R. Lüdtke 79 (ICN); Caçapava do Sul, Cerro do Ricardinho, 12-X-2000, S.A.L. Bordignon \& A. Knob 1952 (HERULBRA); Herval, RS 608, para Pinheiro Machado, 31 ${ }^{\circ} 53^{\prime} 31,2^{\prime \prime} \mathrm{S}, 5^{\circ} 29^{\prime} 33,2^{\prime \prime} \mathrm{W}$, 31-X-2006, R. Lüdtke 639 (ICN); Porto Alegre, Morro da Polícia, X-1944, B. Rambo 27278 (PACA); Quevedos, próximo a ponte sobre o Rio Toropi, 10-IV-2002, S.A.L. Bordignon \& A. Knob 2573 (HERULBRA); Santana do Livramento, próximo ao aeroporto, 19-X-1984, J. Mattos \& N. Silveira 28526 (HAS); Santo Ângelo, 17-XI-1952, B. Rambo 52999 (PACA).

Polygala bonariensis ocorre na Argentina, Uruguai e Brasil, no Estado do Rio Grande do Sul (Grondona 1948, Marques 1988, Lüdtke \& Miotto 2004). Pode ser encontrada em campos graminosos e arbustivos e beira de estradas, em solos secos, pedregosos, lateríticos ou graníticos. Floresce e frutifica em todos os meses do ano.

Apresenta raiz característica, amarela, profunda e rugosa. Pode ser confundida com Polygala duarteana pela semelhança nos frutos e sementes, porém, difere desta por apresentar folhas mais abundantes e menores, com até $16 \times 1 \mathrm{~mm}$.

Bernardi (2000), sinonimizou Polygala bonariensis com P. resedoides A. St.-Hil. \& Moq., citando-a para o Brasil, Argentina e Uruguai. Marques (1988) confirmou a ocorrência de $P$. resedoides somente para o Uruguai embora exista, segundo a autora, uma coleta de Saint Hilaire para o Brasil.

No presente trabalho não se aceita a sinonimização proposta por Bernardi (2000), pois embora a foto do holótipo de $P$. resedoides $(\mathrm{P})$ tenha sido analisada, isso não foi suficiente para concordar com a opinião daquele autor.

3.7. Polygala brasiliensis L., Mant. Plant.: 99. 1767. = P. dunaliana A. St.-Hil. \& Moq., Ann. Soc. Roy, Sci. Art Orleans 9: 51. 1828.

$=$ P. guimaraensii Brade, Arq. Jard. Bot. Rio de Janeiro 13: 23. 1954.

Figura 6a-c

Ervas eretas a decumbentes, 7-72 $\mathrm{cm}$ alt. Caule folioso, cilíndrico, densamente piloso, com tricomas longos, sem glândulas, com ramificação basal mediana ou terminal. Folhas sésseis, alternas, adpressas ao caule, papiráceas, pilosas, sem glândulas, lanceoladas, ovadas, elípticas ou cordiformes, lâminas 2-8,4 × 1-4 mm, ápice agudo ou acuminado, base aguda, arredondada, obtusa ou cordada, margem 

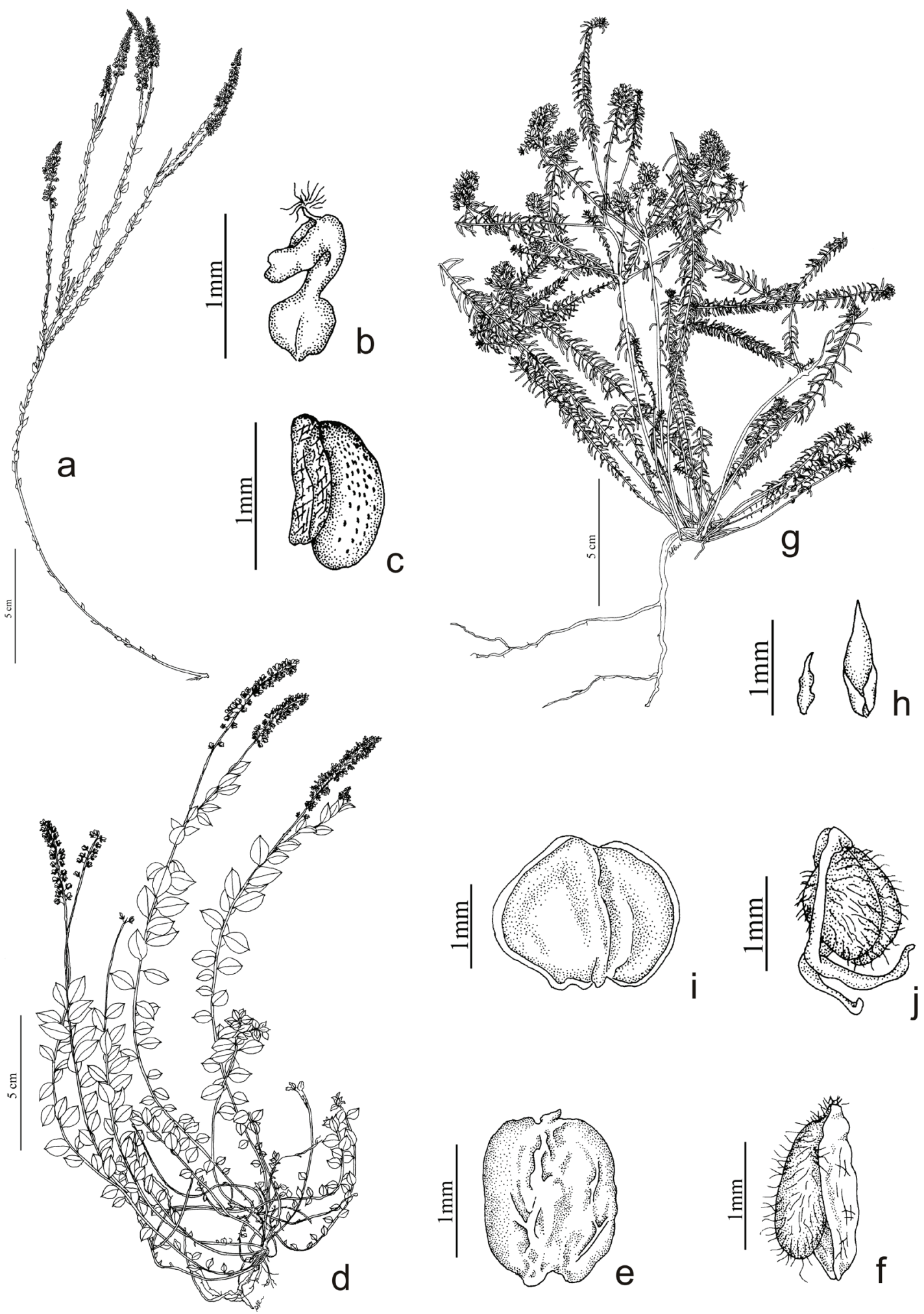

Figura 6. a-c. Polygala brasiliensis. a. Hábito. b. Gineceu. c. Semente. d-f. Polygala campestris. d. Hábito. e. Fruto. f. Semente. g-j. Polygala cyparissias. g. Hábito. h. Bractéola e bráctea. i. Fruto. j. Semente. [a-c: Lüdtke 160 (ICN); d: Lindeman et al. s.n. (ICN9340); e-f: Lüdtke 163 (ICN); g, i: Nunes 604 (HAS); h, j: Lüdtke 186 (ICN)].

Figure 6. a-c. Polygala brasiliensis. a. Habit. b. Gynoecium. c. Seed. d-f. Polygala campestris. d. Habit. e. Fruit. f. Seed. g-j. Polygala cyparissias. g. Habit. h. Bracteole and bract. i. Fruit. j. Seed. [a-c: Lüdtke 160 (ICN); d: Lindeman et al. s.n. (ICN9340); e-f: Lüdtke 163 (ICN); g, i: Nunes 604 (HAS); h, j: Lüdtke 186 (ICN)]. 
obscuramente serreada, ciliada. Brácteas e bractéolas decíduas, margem ciliada. Racemos pedunculados, terminais, estreito-cilíndricos, 1,2-21 cm compr., densifloros. Flores 2-2,6 mm compr., brancas a rosadas; pedicelos 0,3-0,7 mm compr., glabros, eretos na frutificação. Sépalas externas glabras, sem glândulas, ápice obtuso ou agudo, margem ciliada; uma sépala ovado-elíptica ou largo-ovada, 1,2-2 mm compr.; duas sépalas livres e iguais entre si, elípticas ou ovado-elípticas, 1,1-1,8 mm compr.; sépalas internas glabras, sem glândulas, suborbiculares ou largo-espatuladas, 1,8-2,5 mm compr., ápice obtuso ou arredondado, base unguiculada. Pétalas laterais glabras, sem glândulas, elípticas ou rômbicas, 1,8-2,4 mm compr., ápice obtuso; carena cristada, sem glândulas, crista $0,5-1 \mathrm{~mm}$ compr., com 5-8 lobos simples e bífidos. Ovário glabro, sem glândulas, cordiforme ou oblongo. Cápsulas pilosas com tricomas escassos e curtos, sem glândulas, oblongas ou suborbiculares, 1-1,6 mm compr., não estipitadas, aladas, emarginadas nos dois bordos. Sementes glabras, ovoides, 1-1,3 mm compr., com apêndice membranáceo profundamente bilobado, atingindo de $1 / 2$ ao comprimento total da semente.

Material selecionado: BRASIL. Paraná: Curitiba, Capão da Imbuia, 8-I-1975, L.T. Dombrowski 5706 (MBM); Guarapuava, Fazenda Reserva, 21-III-1967, J.C. Lindeman \& J.H. Haas 5060 (U); Itaperussú, 27-IX-1914, G. Jönsson $992 a$ (NY, S); Lapa, BR 427, km 40, 2542'53,9"S, 4946'34,3"W, 22-II-2006, R. Lüdtke 529 (ICN); Palmeira, 20 km de Palmeira, próximo ao Rio dos Papagaios, 14-X-1966, J.C. Lindeman \& J.H. Haas 2684 (NY); Tibagi, Fazenda Monte Alegre, 5-I-1954, G. Hatschbach 3375 (HBR, MBM); União da Vitória, 27-XII-1967, C. Koczicki 37 (MBM). Rio Grande do Sul: Bagé, BR 293, $2 \mathrm{~km}$ do trevo de acesso a Bagé, em direção a Pelotas, 8-I-2003, R. Lüdtke 130 (ICN); Cachoeira do Sul, BR 290, km 261, 27-XII-2004, R. Lüdtke 348 (ICN); Giruá, Granja Sodol, X-1963, K. Hagelund 1195 (ICN); Ijuí, perto de Tupanciretã, 30-I-1942, B. Rambo 10032 (PACA); Lagoa Vermelha, I-1943, E. Friderichs s.n. (PACA11065); Porto Alegre, Morro São Pedro, 30¹1'01,3"S, 51ํ6'43,6"W, 14-XI-2005, S.T.S. Miotto 2244 (ICN); Santana da Boa Vista, Cerro das Burras, 11-X-1987, J.A. Jarenkow \& M. Sobral 782 (PEL); Soledade, BR 386, km 262, $28^{\circ} 55^{\prime} 16,2^{\prime \prime S}, 52^{\circ} 22^{\prime} 55,3^{\prime \prime} \mathrm{W}, 9-\mathrm{X}-2006$, R. Lüdtke 578 (ICN); Vacaria, BR 116, km 33, 28 27'49,5"S, 5053'24,3"W, 21-XII-2006, R. Lüdtke, 695 (ICN).
Santa Catarina: Bom Retiro, BR 282, km 132, 274'39,0"S, 49³1'04,1"W, 29-XI-2006, R. Lüdtke 672 (ICN); Capão Alto, BR 116, km 294, 280'18,2"S, 50³8'51,7"W, 11-X-2006, R. Lüdtke 599 (ICN); Lages, BR 116, km 231, em direção a Correia Pinto, 2741'52,8"S, 50²0'04,3"W, 14-XII-2004, R. Lüdtke 322 (ICN); Santa Cecília, BR 116, km 143, $26^{\circ} 59.199^{\prime} \mathrm{S}, 50^{\circ} 23.689^{\prime} \mathrm{W}, 20-\mathrm{X}-2005$, R. Lüdtke 415 (ICN); Urubici, Rodovia Manoel Correa Neto, a $1 \mathrm{~km}$ do trevo da SC 438, em direção a Urubici, $28^{\circ} 13^{\prime} 40,0^{\prime \prime} \mathrm{S}, 4^{\circ} 48^{\prime} 55,0^{\prime \prime} \mathrm{W}, 10-\mathrm{I}-2006$, R. Lüdtke 495 (ICN).

Polygala brasiliensis ocorre na Argentina, Paraguai, Uruguai e Brasil: Minas Gerais, Rio de Janeiro, São Paulo, Paraná, Santa Catarina e Rio Grande do Sul (Grondona 1948, Angely 1965, Wurdack \& Smith 1971, Marques 1988, Bernardi 2000, Marques \& Gomes 2002, Lüdtke \& Miotto 2004). Trata-se de espécie muito comum, de ampla distribuição, podendo ser encontrada em campos graminosos ou arbustivos, com solos secos, úmidos, rochosos, baixadas úmidas, turfeiras, banhados, morros graníticos e beira de estradas. Floresce e frutifica em todos os meses do ano.

Caracteriza-se pelas folhas geralmente adpressas ao caule e por ser a única espécie de Polygala ocorrente na região Sul do Brasil a apresentar sementes glabras.

3.8. Polygala campestris Gard., J. Bot. 2: 332. 1843. Figura 6d-f

Ervas decumbentes ou prostradas, $20-42 \mathrm{~cm}$ alt. Caule folioso, quadrangular ou cilíndrico, estriado, escassamente piloso, com tricomas curtos, sem glândulas, simples ou com ramificação basal, mediana ou terminal. Folhas sésseis, alternas, papiráceas, pilosas, sem glândulas, lanceoladas, ovadas, largo-ovadas, estreito-elípticas a largo-elípticas, lâminas 3-18 × 1,5-12 mm, ápice mucronado, apiculado, acuminado ou cuspidado, base obtusa, atenuada ou cuneada, margem serreada, ciliada. Brácteas e bractéolas decíduas, margem lisa ou ciliada. Racemos pedunculados, terminais, cilíndricos, 2-14 cm compr., laxifloros. Flores 3-4,3 mm compr., lilases, roxas ou azuis; pedicelos 1-2 mm compr., glabros, patentes ou reflexos na frutificação. Sépalas externas glabras, sem glândulas, ápice agudo, margem inteira; uma sépala largo-ovada, 1,7-2,2 mm compr.; duas sépalas livres e iguais entre si, lanceoladas, 1,3-1,9 mm compr.; sépalas internas glabras, sem glândulas, largo-obovadas, 3,1-4,3 mm compr., ápice 
obtuso ou arredondado, base atenuada ou aguda. Pétalas laterais glabras, sem glândulas, elíptico-assimétricas, 2,1-3 mm compr., ápice obtuso; carena cristada, sem glândulas, crista 1-1,5 mm compr., com 8-12 lobos simples. Ovário glabro, sem glândulas, suborbicular ou largo-elíptico. Cápsulas glabras, sem glândulas, oblongas ou largo-elípticas, 1,5-2,1 mm compr., não estipitadas, não aladas. Sementes pubescentes, oblongas ou elipsoides, 1,6-1,8 mm compr., com apêndice membranáceo profundamente bilobado, atingindo de $2 / 3$ ao comprimento total da semente.

Material selecionado: BRASIL. PARANÁ: Guaratuba, Serra do Araçatuba, 15-IX-1982, R. Kummrow 2024 (NY); Morretes, BR 277, 17-I-1969, G. Hatschbach \& J.P. Fontella 20823 (RB); Piraquara, Nova Tirol, 30-X-1967, G. Hatschbach 17676 (F, MBM, NY); Quatro Barras, Rio Taquari, 9-VIII-1974, G. Hatschbach 34556 (MBM); Tijucas do Sul, Campo Alto, 16-XII-1981, R. Kummrow 1590 (BM, MBM). Rio Grande do Sul: Bom Jesus, 15-XI-2003, R. Wasum \& J. Bordin 2072 (HUCS, MBM); Cambará do Sul, Cânion Fortaleza, 15-I-2003, R. Lüdtke 163 (ICN); Campestre da Serra, BR 116, km 68, 3-XI-2003, R. Lüdtke 197 (ICN); Canela, 25-IV-1976, S.T.S. Miotto 44 (ICN); Carazinho, Granja Pinheirinho, 2-X-1971, J.C. Lindeman et al. s.n. (ICN8214). Esmeralda, XI-1984, J.R. Stehmann 361 (ICN); Panambi, 15-X-1905, A. Bornmüller 594 (GH); São Francisco de Paula, RS 484, para o Pró-Mata, 18-XI-2004, R. Lüdtke 286 (ICN); São José dos Ausentes, Pico do Montenegro, 14-I-2001, S.T.S. Miotto 1929 (ICN); Vacaria, perto do Rio das Antas, 27-II-1946, B. Rambo 32357 (PACA). SANTA CAtARINA: Araranguá, Serra da Pedra, 12-XII-1943, R. Reitz 338 (GH, HBR); Bom Jardim da Serra, Curral Falso, 10-XII-1958, R. Reitz \& R. Klein 7746 (B, F, HBR, MBM, PACA); Bom Retiro, Campo dos Padres, 16-XII-1948, R. Reitz 2380 (HBR; aruva (São Francisco do Sul), Monte Cristo, 6-X-1960, R. Reitz \& R. Klein 9986 (HBR, NY); Grão Pará, Serra do Corvo Branco, 19-XI-2004, G. Hatschbach et al. 78231 (MBM); Rancho Queimado, BR 282, km 58, em frente a Polícia Rodoviária Federal, 27041'16,6"S, 4902'06,6"W, 29-XI-2006, R. Lüdtke 675 (ICN); Santa Cecília, Campo Alto, 25-X-1962, R. Reitz \& R. Klein 13483 (B, HBR); São Joaquim, Morro da Igreja, I-1960, J. Mattos s.n. (HAS83745); Urubici, descida do Morro da Igreja, 20-X-2004, R. Lüdtke 253 (ICN).
Polygala campestris ocorre no Brasil: Minas Gerais, Espírito Santo, Rio de Janeiro, São Paulo, Paraná, Santa Catarina e Rio Grande do Sul (Angely 1965, Wurdack \& Smith 1971, Marques 1988, Bernardi 2000, Marques \& Gomes 2002, Lüdtke \& Miotto 2004). É encontrada preferencialmente em campos de altitude, nas bordas e no interior da matinha nebular, nas proximidades dos cânions dos Aparados da Serra. Encontrada com menor frequência em beira de estradas, campos úmidos, pedregosos, solos brejosos e encostas rochosas. Floresce e frutifica em todos os meses do ano.

Pode ser confundida com Polygala linoides, principalmente pelo hábito e distribuição geográfica, porém, difere desta por apresentar folhas numerosas, brácteas florais com margem ciliada e pela carena, geralmente dividida em um número maior de lobos (8-12), sendo, às vezes, muito difícil distingui-las morfologicamente.

3.9. Polygala cyparissias A. St.-Hil. \& Moq., Ann. Roy. Sci. Art. Orleans 9: 47. 1828.

Figura $6 \mathrm{~g}-\mathrm{j}$

Subarbustos decumbentes, $19-46 \mathrm{~cm}$ alt. Caule folioso, cilíndrico, fortemente estriado, glabro, sem glândulas, com ramificação basal, mediana ou terminal. Folhas sésseis, alternas, carnosas, glabras, sem glândulas, filiformes, lâminas 3,5-10 × 0,5-1,3 mm, ápice mucronado, base atenuada, margem lisa. Brácteas e bractéolas decíduas, margem lisa. Racemos sésseis, subsésseis ou pedunculados, terminais, capitados, subcapitados ou curto-cilíndricos, 1-4,3 cm compr., densifloros. Flores 4-5,3 mm compr., brancas com manchas roxas; pedicelos 1,8-2,2 mm compr., glabros, eretos na frutificação. Sépalas externas glabras, sem glândulas, ápice agudo, margem inteira; uma sépala ovada ou ovado-elíptica, 2,1-2,5 mm compr.; duas sépalas unidas e iguais entre si, elípticas, 2-3 mm compr.; sépalas internas glabras, sem glândulas, elípticas, 3,5-5 mm compr., ápice mucronulado, base atenuada. Pétalas laterais pilosas internamente ou na parte basal, sem glândulas, elípticas, 3,2-4 mm compr., ápice obtuso ou emarginado; carena cristada, sem glândulas, crista 1-2 mm compr., com 6-8 lobos simples, bífidos e trífidos. Ovário glabro, sem glândulas, elíptico. Cápsulas glabras, sem glândulas, ovado-orbiculares, suborbiculares ou cordiformes, 2-2,8 mm compr., estipitadas, aladas, emarginadas nos dois bordos. Sementes pubescentes, globosas, 1,3-2 mm compr., com apêndice membranáceo, estreito, profundamente bilobado, ultrapassando de 1 a $1,5 \mathrm{~mm}$ a semente. 
Material selecionado: BRASIL. ParanÁ: Curitiba, Jardim Petrópolis, 5-XI-1992, J.M. Silva 1161 (MBM); Guaratuba, dunas na beira da praia, $25^{\circ} 55^{\prime} 25,4^{\prime \prime}$, 48³4'43,4"W, 8-I-2007, R. Lüdtke 706 (ICN); Matinhos, Balneário Praia do Leste, 25041'51,9"S, 48⒉ 08,7"W, 24-II-2006, R. Lüdtke 544 (ICN); Piraquara, Florestal, 7-IX-1946, G. Hatschbach 370 (PACA); Tijucas do Sul, Campina, 3-V-1984, R. Kummrow 2460 (MBM). Rio Grande do Sul: Balneário Pinhal, 26-I-2003, R. Lüdtke 186 (ICN); Capão da Canoa, 22-XI-1987, S.N.S. Brito s.n. (ICN80385); Cidreira, RS 786, km 8, 17-I-2003, R. Lüdtke 180 (ICN); Pelotas, Praia do Laranjal, 19-VII-1987, J.A. Jarenkow 718 (PEL); Rio Grande, Ilha dos Marinheiros 24-XI-1892, G. Malme 364 (GH); Quintão, 27-I-2004, F. Soares 8 (HUCS22480); Rondinha Velha, 27-X-1987, C. Mondin \& V. Manfroi 248 (HAS); Santa Vitória do Palmar, Estação Ecológica do Taim, 4-XI-1985, J.A. Jarenkow et al. 292 (PEL); São José do Norte, X-1991, P. Tagliani s.n. (HURG2224); Torres, Praia de Itapeva, 19-I-2003, R. Lültke 185 (ICN). SANTA CATARINA: Aquaraí, Barra do Sul, 10-VIII-1953, R. Reitz \& R. Klein 928 (HBR, NY, U); Florianópolis, Praia Daniela, 27²6'45,9"S, 4831'33,0"W, 28-XI-2006, R. Lüdtke 662 (ICN); Garuva (São Francisco do Sul), Barra do Saí, Guaçú, 3-I-1954, R. Reitz \& R. Klein 1452 (HBR); Imbituba, Ibiraquara, 21-V-1985, G. Hatschbach 49365 (HAS, MBM); Itajaí, Praia Brava, 3-XI-1948, R. Reitz 3789 (PACA); Itapoá, 2601'59,9"S, 48³6'30,1"W, 12-I-2006, R. Lüdtke 508 (ICN); Laguna, 28 28'31,5"S, 4846'05,7"W, 13-I-2006, R. Lüdtke 510 (ICN).

Polygala cyparissias ocorre na Argentina, Uruguai e Brasil: Ceará, Paraíba, Pernambuco, Alagoas, Bahia, Rio de Janeiro, São Paulo, Paraná, Santa Catarina e Rio Grande do Sul (Wurdack \& Smith 1971, Marques 1988, Bernardi 2000, Marques \& Gomes 2002, Lüdtke \& Miotto 2004). É uma espécie exclusiva de dunas costeiras, antedunas e restingas litorâneas. Floresce e frutifica em todos os meses do ano.

Pode ser confundida, no aspecto geral, com Polygala sabulosa, mas difere desta por apresentar cápsula alada e sementes globosas bem distintas, com apêndice membranáceo estreito e muito comprido, ultrapassando em 1 a 1,5 $\mathrm{mm}$ a semente, bem como pela ausência de glândulas nas sépalas e pétalas. Também assemelha-se muito à $P$. aspalatha, que apresenta folhas mais estreitas e longas, com até $17 \times 1 \mathrm{~mm}$ e sépalas internas mais compridas, com $2,2 \mathrm{~mm}$ de comprimento. Como já discutido anteriormente, P. aspalatha possui brácteas e bractéolas tardiamente caducas e folhas membranáceas, enquanto que em $P$. cyparissias as brácteas e as bractéolas são cedo-caducas e as folhas são carnosas. Dentre as três espécies citadas, $P$. cyparissias é a única que ocorre em dunas litorâneas.

3.10. Polygala densiracemosa Lüdtke \& Miotto, Novon 20: 175. 2010.

Figura $7 \mathrm{a}-\mathrm{c}$

Ervas decumbentes a cespitosas, $11-45 \mathrm{~cm}$ alt. Caule folioso, quadrangular, glabro ou escassamente piloso, com tricomas curtos, sem glândulas, com intensa ramificação basal. Folhas sésseis, alternas, papiráceas, glabras ou raramente pilosas, sem glândulas, ovadas, elípticas ou oblongas, lâminas 2-11 × 2-5 mm, ápice mucronado, apiculado ou acuminado, base atenuada, margem inteira, lisa ou raramente ciliada. Brácteas e bractéolas decíduas, margem lisa. Racemos pedunculados, terminais, cilíndricos, 3-12 cm compr., densifloros. Flores 2-2,5 mm compr., brancas com manchas violáceas ou azuis; pedicelos $1 \mathrm{~mm}$ compr., glabros, patentes ou reflexos na frutificação. Sépalas externas glabras, sem glândulas, ápice obtuso ou agudo, margem inteira; uma sépala largo-ovada, 1,2-1,3 mm compr.; duas sépalas livres e iguais entre si, elípticas ou ovadas, 1-1,2 mm compr.; sépalas internas glabras, sem glândulas, espatuladas ou elípticas, 2-2,6 mm compr., ápice arredondado, base atenuada. Pétalas laterais glabras, sem glândulas, elípticas, 1,5-2 mm compr., ápice obtuso; carena cristada, sem glândulas, crista 0,8-1 mm compr., com 6 lobos simples. Ovário glabro, sem glândulas, suborbicular ou largo-elíptico. Cápsulas glabras, sem glândulas, largo-elípticas a suborbiculares, 1,1-2 mm compr., levemente estipitadas, não aladas. Sementes pubérulas, elipsoides, 1,2-1,8 $\mathrm{mm}$ compr., com apêndice membranáceo profundamente bilobado, atingindo de $1 / 5$ ao comprimento total da semente.

Material selecionado: BRASIL. Rio GRANDE Do Sul: Almirante Tamandaré do Sul, BR 386, km 160, $28^{\circ} 10^{\prime} 34,3^{\prime \prime S}, 52^{\circ} 50^{\prime} 10,9 " \mathrm{~W}, 9-\mathrm{X}-2006$, R. Lüdtke 581 (ICN); Campestre da Serra, BR 116, km 76, $28^{\circ} 46^{\prime} 13,2^{\prime \prime S}, 51^{\circ} 05^{\prime} 32,2^{\prime \prime} \mathrm{W}, 5-\mathrm{XI}-2007$, R. Lüdtke 768 (ICN); Caseiros, BR 285, km 232, 4-XI-2003, R. Lüdtke 199 (ICN); Cruz Alta, BR 377, km 94 $28^{\circ} 37^{\prime} 40,6^{\prime \prime} \mathrm{S}, 53^{\circ} 27^{\prime} 41,7^{\prime \prime} \mathrm{W}, 3-\mathrm{X}-2007$, R. Trevisan 838 (ICN); Esmeralda, $8 \mathrm{~km}$ da entrada de Muitos 

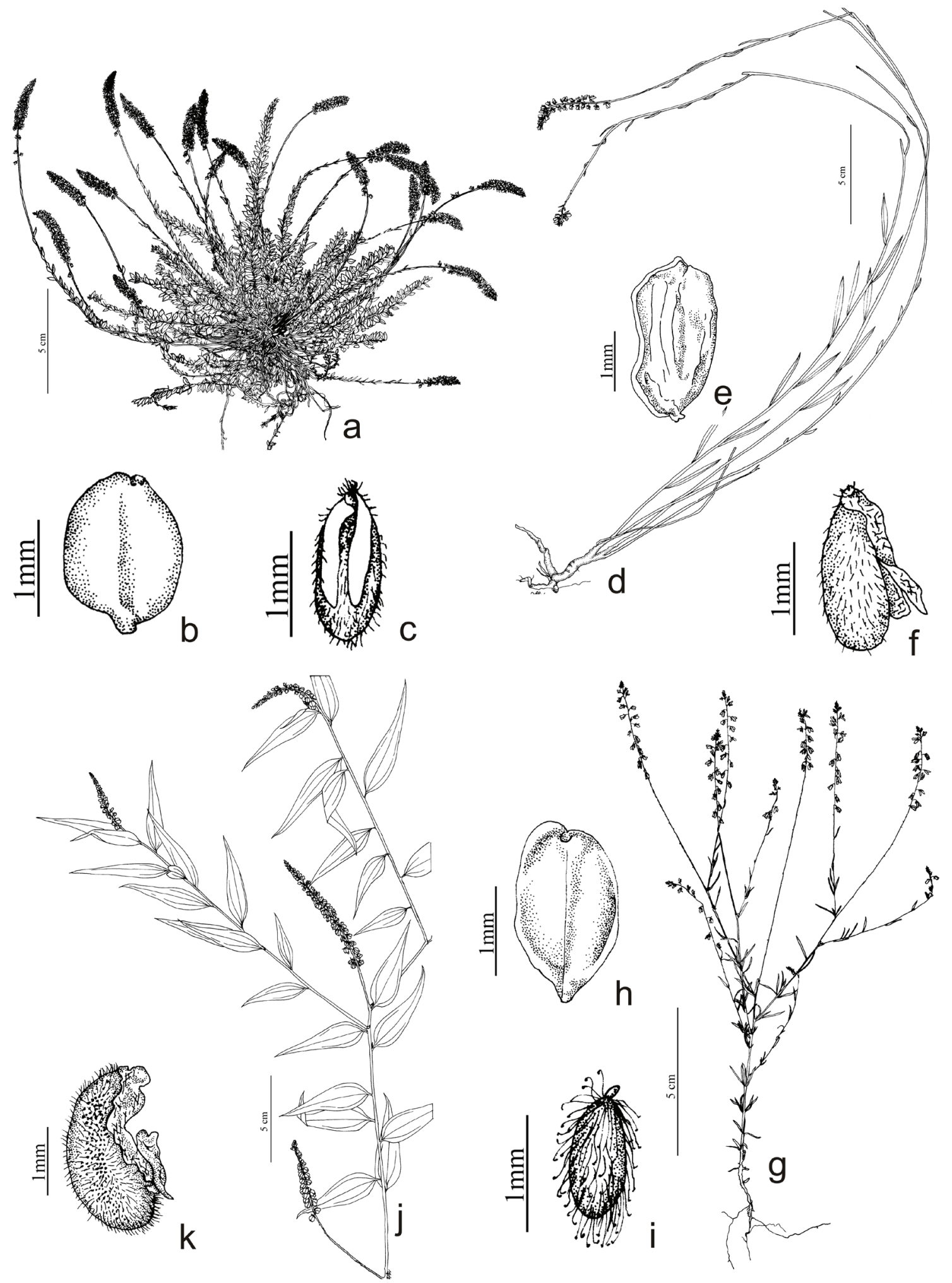

Figura 7. a-c. Polygala densiracemosa. a. Hábito. b. Fruto. c. Semente. d-f. Polygala duarteana. d. Hábito. e. Fruto. f. Semente. g-i. Polygala glochidiata. g. Hábito. h. Fruto. i. Semente. j-k. Polygala lancifolia. j. Hábito. k. Semente. [a-c: Lüdtke 193 (ICN); d-f: Lüdtke 81(ICN); g: Lüdtke 722 (ICN); h-i: Lüdtke 741 (ICN); j-k: Hatschbach 44363 (MBM)].

Figure 7. a-c. Polygala densiracemosa. a. Habit. b. Fruit. c. Seed. d-f. Polygala duarteana. d. Habit. e. Fruit. f. Seed. g-i. Polygala glochidiata. g. Habit. h. Fruit. i. Seed. j-k. Polygala lancifolia. j. Habit. k. Seed. [a-c: Lüdtke 193 (ICN); d-f: Lüdtke 81(ICN); g: Lüdtke 722 (ICN); h-i: Lüdtke 741 (ICN); j-k: Hatschbach 44363 (MBM)]. 
Capões, 27-XII-2002, R. Lüdtke 108 (ICN); idem, Estação Ecológica Aracuri, 12-XII-1982, S.T.S. Miotto s.n. (ICN648751); Fontoura Xavier, BR 386, 28 53'18,1"S, 52²5'05,3"W, 2-X-2007, R. Trevisan 837 (ICN); Jaquirana, a $3 \mathrm{~km}$ da cidade, 3-XI-2002, R. Lüdtke 34 (ICN); Júlio de Castilhos, BR 158, 29¹5'04,3"S, 5339'54,1"W, 3-X-2007, R. Trevisan 847 (ICN); São Francisco de Paula, RS $020,29^{\circ} 24.744$ 'S, $50^{\circ} 28.289^{\prime} \mathrm{W}, 25-\mathrm{XI}-2004$, R. Lüdtke 288 (ICN); Vacaria, BR 116, no trevo de saída para Caxias do Sul, fim da zona urbana, 28-XII-2002, R. Lüdtke 119 (ICN). Santa Catarina: Bom Jardim da Serra, SC 438, 19-X-2004, R. Lüdtke 244 (ICN); Painel, SC 438, km 15, 275'ㄹ'23"S, 50¹0'44,6"W, 6-XI-2007, R. Lüdtke 781 (ICN); São Joaquim, km 52 da rodovia Lages - São Joaquim, entrada da Fazenda Bela Vista, 20-X-2004, R. Lüdtke $266(\mathrm{ICN})$.

Polygala densiracemosa ocorre no Brasil: Santa Catarina e Rio Grande do Sul. A espécie é encontrada em campos, beira de estradas com solos secos. Floresce e frutifica de outubro a dezembro.

Polygala densiracemosa era identificada nos herbários como P. campestris, pela aparente semelhança no hábito e por ambas ocorrerem em campos de altitude. Porém, $P$. densiracemosa apresenta, preferencialmente, hábito cespitoso característico, além de possuir racemos muito densos, enquanto em $P$. campestris, a maioria dos indivíduos apresenta hábito prostrado e os racemos são laxos. As flores de $P$. densiracemosa são menores, com 2-2,5 mm de comprimento e brancas e em P. campestris as flores são geralmente azuis ou roxas e atingem 3-4,3 mm de comprimento. Além de possuir as peças florais maiores, P. campestris apresenta a crista da carena dividida num número maior de lobos (8-12), enquanto que em $P$. densiracemosa a carena apresenta seis lobos.

Outra espécie que se aproxima deste táxon é Polygala linoides, principalmente pelo tamanho das peças florais. Entretando, o hábito em $P$. linoides é sempre ereto e em $P$. densiracemosa é geralmente cespitoso. Adensidade das folhas também é importante fator para diferenciar estes dois táxons. Polygala linoides apresenta folhas mais escassas enquanto que em $P$. densiracemosa as folhas são abundantes. Embora ambas ocorram em campos de altitude, $P$. linoides habita locais de solos muito úmidos como banhados e turfeiras, enquanto $P$. densiracemosa ocorre em solos secos de beira de estradas.
3.11. Polygala duarteana A. St.-Hil. \& Moq., Mém. Mus. Hist. Nat. 17: 369. 1828.

$=$ P. pseudolaurifolia Chodat, Bull. Herb. Bois. 4: 235, 1896.

Figura 7d-f

Subarbustos eretos, $26-56 \mathrm{~cm}$ alt. Caule esparsamente folioso, cilíndrico, levemente estriado, escassamente piloso, com tricomas curtos, sem glândulas, simples ou com ramificação basal ou mediana. Folhas sésseis, alternas, membranáceas, pilosas, sem glândulas, estreito-lineares, lineares, estreito-elípticas a largo-elípticas, lâminas 4,2-47 × 1-4,5 mm, ápice agudo ou acuminado, base atenuada ou cuneada, margem lisa ou denticulada. Brácteas e bractéolas decíduas, margem lisa ou ciliada. Racemos pedunculados, terminais, estreito-cilíndricos, 2,7-19,5 cm compr., laxifloros. Flores 2,5-3,2 mm compr., brancas ou com manchas rosadas; pedicelos 0,8-1,2 mm compr., glabros, eretos na frutificação. Sépalas externas glabras, sem glândulas, ápice obtuso ou agudo, margem inteira ou ciliada; uma sépala ovada, 1,9-2,2 mm compr.; duas sépalas livres e iguais entre si, lanceoladas, 1,3-2 mm compr.; sépalas internas glabras, sem glândulas, orbiculares ou largo-obovadas, 2,5-3,5 mm compr., ápice arredondado, base atenuada. Pétalas laterais glabras, sem glândulas, elípticas, 2,5-3 mm compr., ápice obtuso; carena cristada, sem glândulas, crista 1-1,5 mm compr., com 6-10 lobos simples. Ovário glabro, sem glândulas, oblongo. Cápsulas glabras, sem glândulas, oblongas, 3-3,7 mm compr., não estipitadas, aladas, emarginadas nos dois bordos. Sementes pubescentes, retas, cilíndricas ou estreito-cilíndricas, 2-2,8 mm compr., com apêndice membranáceo profundamente bilobado, atingindo a metade ou ultrapassando $0,3 \mathrm{~mm}$ da semente.

Material selecionado: BRASIL. Rio GRAnde Do Sul: Alegrete, 25-I-1971, A. Pott 87 (BLA); Bagé, BR 153, km 628, 23-XI-2002, R. Lüdtke 78 (ICN); Barra do Quaraí, Rio Garopá, 14-I-1941, B. Rambo 4164 (PACA); Caçapava do Sul, BR 153, em direção a Bagé, 21-XI-2003, S.T.S. Miotto 2149 (ICN); Quaraí, Cerro do Jarau, subida para o morro, 28-XII-2004, R. Lüdtke 368 (ICN); Santana do Livramento, $36 \mathrm{~km}$ após a cidade, em direção a Barra do Quaraí, estrada secundária, 12-I-2002, S.T.S. Miotto 2015 (ICN); Santiago, $57 \mathrm{~km}$ após São Borja para Santiago, 20-XII-1972, A. Pott et al. s.n. (BLA7918, ICN23394, SMDB1985); São Borja, A. Pott s.n. (BLA 7880, SMDB1984); São Gabriel, BR 290, 12-III-2002, S.A.L. Bordignon \& A. Knob 2517 (HERULBRA); 
São Miguel das Missões, $5 \mathrm{~km}$ do pórtico de entrada, 5-XI-2003, R. Lüdtke 207 (ICN); Uruguaiana, Arroio Imbará, 16-X-1984, M. Sobral et al. 3379 (B, F, ICN, MBM, RB).

Polygala duarteana ocorre na Argentina, Uruguai e no Brasil apenas no Estado do Rio Grande do Sul (Grondona 1948, Angely 1965, Marques 1988, Bernardi 2000, Lüdtke \& Miotto 2004). Pode ser encontrada em beiras de estradas, barrancos úmidos e secos, em solos lateríticos, pedregosos, bem como em campos de baixadas úmidas. Floresce e frutifica de setembro a abril.

Assim como em Polygala bonariensis, pode-se observar a presença, em alguns indivíduos, de raiz rugosa, amarelada e, às vezes, longa, podendo ser facilmente confundida com um xilopódio. Além disso, $P$. duartena assemelha-se à $P$. bonariensis em outros caracteres anteriormente citados, porém, difere desta por apresentar as folhas escassas e maiores, $47 \times 4,5 \mathrm{~mm}$.

3.12. Polygala glochidiata Kunth, Nov. Gen. Sp. P1. 5: 400. 1823.

= P. minima Pohl. ex A.W. Benn. Fl. bras. 13(3): 30 . 1874.

Figura $7 \mathrm{~g}-\mathrm{i}$

Ervas ou subarbustos eretos, $10-21 \mathrm{~cm}$ alt. Caule folioso, cilíndrico, piloso, tricomas curtos, clavados, sem glândulas, com ramificação basal, mediana e terminal. Folhas pecioladas, verticiladas na maior extensão, alternas no ápice da planta, papiráceas, glabras, sem glândulas, estreito-lineares, lâminas 3-16 × 0,3-1 mm, ápice acuminado, base atenuada, margem inteira, lisa; pecíolos 0,3-0,5 mm compr. Brácteas e bractéolas decíduas, margem lisa. Racemos pedunculados, terminais, cilíndricos, $2-13 \mathrm{~cm}$ compr., laxifloros. Flores 2,3-3 mm compr., brancas ou creme, pedicelos 0,8-1,5 mm compr., glabros, reflexos na frutificação. Sépalas externas glabras, sem glândulas, ápice agudo ou obtuso, margem lisa; uma sépala largo-ovada, 1-1,5 mm compr.; duas sépalas livres e iguais entre si, ovadas ou elípticas, 1-1,2 mm compr.; sépalas internas glabras, sem glândulas, elípticas ou oblongas, 2,2-2,8 mm compr., ápice arredondado, base atenuada. Pétalas laterais glabras, sem glândulas, elípticas ou rômbicas, 1,8-2,2 mm compr., ápice arredondado; carena cristada, sem glândulas, crista com 0,5-0,8 mm compr., com 4-5 lobos simples e bífidos. Ovário glabro, sem glândulas, elíptico. Cápsulas glabras, sem glândulas, elípticas,
1,7-2,4 mm compr., não estipitadas, não aladas. Sementes pilosas, ovoides ou elipsoides, 1-1,2 mm compr., tricomas gloquidiados, sem apêndice membranáceo.

Material selecionado: BRASIL. ParanÁ: Arapoti, Rio das Cinzas, Barra das Perdizes, 24-X-1961, G. Hatschbach 8487 (MBM); Guarapuava, Três Capões, 8-XII-1982, G. Hatschbach 45799 (MBM, RB); Jaguariaíva, Parque Estadual do Cerrado, 24¹2'38,2"S, 4941'04,3"W, 10-I-2007, R. Lüdtke, 722 (ICN); Ponta Grossa, Parque Estadual Vila Velha, 25-I-1910, P. Dusén 9107 (S); Sengés, PR 151, 24¹0'20,4"S, 49³5'24,6"W, 10-I-2007, R. Lüdtke 740 (ICN); Tibagi, Guartelá, Riacho do Pedregulho, 28-X-1992, A.C. Cervi et al. s.n. (FUEL20866, HUPG6229); Ventania, Morro do Chapéu, $18 \mathrm{~km}$ estrada Ventania-Ibaiti, 8-VI-2005, D.A. Estevan et al. 742 (FUEL, ICN).

Polygala glochidiata ocorre na Argentina e Brasil: Paraíba, Bahia, Mato Grosso, Minas Gerais, Rio de Janeiro, São Paulo e Paraná (Grondona 1948, Marques 1988, Marques \& Gomes 2002). É encontrada em campos graminosos e arbustivos de solos secos ou úmidos, brejos, campos rupestres e beira de estradas. Polygala glochidiata é muito abundante no Cerrado paranaense e adjacências, podendo ser encontrada nos mais diversos ambientes. Floresce e frutifica em todos os meses do ano.

As espécies de Polygala ocorrentes na região Sul do Brasil, P. glochidiata, juntamente com P. adenophylla e P. molluginifolia, formam o grupo das espécies com folhas verticiladas, como anteriormente salientado. O que separa $P$. glochidiata das demais espécies é a presença de tricomas gloquidiados e a ausência de apêndices membranáceos na semente. Além disso, apresenta folhas pecioladas e não há indícios de glândulas em qualquer parte da planta, diferentemente de $P$. adenophylla e P. molluginifolia que são espécies glandulosas e com folhas sésseis.

3.13. Polygala lancifolia A. St.-Hil. \& Moq., Ann. Soc. Roy. Sci. Art Orleans 9: 53. 1828. Figura $7 \mathrm{j}-\mathrm{k}$

Subarbustos eretos, subdecumbentes ou prostrados e apoiantes, $20-156 \mathrm{~cm}$ alt. Caule folioso, cilíndrico, densamente piloso, com tricomas curtos, sem glândulas, com ramificação basal, mediana ou terminal. Folhas pecioladas, alternas, membranáceas a papiráceas, pilosas, sem glândulas, lanceoladas 
a ovado-lanceoladas, ovado-elípticas ou elípticas, lâminas 5-54 × 2-27 mm, ápice mucronado, obtuso, acuminado ou cuspidado, base aguda ou obtusa, margem serreada, ciliada; pecíolo 1,5-3 mm compr. Brácteas e bractéolas decíduas, margem ciliada. Racemos pedunculados, terminais, cilíndricos, 1-6 cm compr., laxifloros. Flores 2,3-3,2 mm compr., brancas, creme a esverdeadas; pedicelos $0,5-1 \mathrm{~mm}$ compr., glabros, reflexos na frutificação. Sépalas externas glabras, sem glândulas, ápice agudo, margem ciliada; uma sépala ovada, 1,5-2,1 mm compr.; duas sépalas livres e iguais entre si, ovado-elípticas, 1,3-1,8 mm compr.; sépalas internas glabras, sem glândulas, suborbiculares, obovado-elípticas, largo-obovadas ou largo-ovadas, 2,3-3 mm compr., ápice arredondado, base aguda. Pétalas laterais glabras, sem glândulas, elípticas, 2-2,5 mm compr., ápice obtuso; carena cristada, sem glândulas, crista 0,9-1,1 mm compr., com 3-6 lobos simples e bífidos. Ovário glabro, sem glândulas, suborbicular ou cordiforme. Cápsulas glabras ou pubérulas com tricomas escassos e curtos, sem glândulas, oblongas ou suborbiculares, 2,5-4,3 mm compr., não estipitadas, aladas, emarginadas nos dois bordos. Sementes pubérulas, estreito-oblongas, 2,5-3,3 mm compr., com apêndice membranáceo inteiro ou levemente bilobado, atingindo de $4 / 5$ ao comprimento total da semente.

Material selecionado: BRASIL. PARANÁ: Almirante Tamandaré, Rio Baguiri, 22-VII-1970, G. Hatschbach \& O. Guimarães 24522 (MBM, NY); Balsa Nova, Chácara Payquerê, Bugre, 18-XII-2002, E.E. Kauano 14 (MBM); Bocaiúva do Sul, entre Bocaíuva e Curitiba, 13-VII-1938, J.E. Rombouts s.n. (IAC2585); Contenda, Serrinha, 17-XI-1972, G. Hatschbach 30637 (MBM); Piraí do Sul, PR 151,

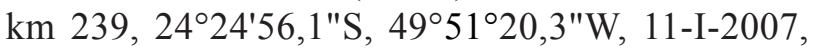
R. Lüdtke \& L.F. Lima 744 (ICN); Ponta Grossa, Passo do Pupo, 12-X-1995, C.B. Poliquesi \& J.M. Cruz 481 (NY, MBM, PEL); Tijucas do Sul, BR 376, km 37, 4-XI-1988, R. Kummrow et al. 3093 (HUCS, MBM); Tunas do Paraná, PR 092, em direção a Cerro Azul, 245'ㄴ' 3 ,2"S, 4906'48,9"W, 9-I-2007, R. Lüdtke 717 (ICN). Rio Grande Do Sul: Agudo, Cerro Agudo, IX-1985, M. Sobral et al. 4351 (ICN, MBM, NY); Barracão, a 1 km da Vila Espigão Alto em direção a Linha Aparecida, 29-XI-2002, R. Lüdtke 87 (ICN); Esmeralda, Estação Ecológica de Aracuri, 10-XI-1984, S.T.S. Miotto 1011 (ICN); Jaquirana, 285' $38,2^{\prime \prime} \mathrm{S}, 50^{\circ} 21^{\prime} 48,9^{\prime \prime} \mathrm{W}, 6-\mathrm{XI}-2006$, A.A. Schneider 1435 (ICN); Nonoai, Rio Uruguai,
III-1945, B. Rambo 28201 (PACA); Novo Hamburgo, 18-X-1892, G.A. Malme 182 (BM, S); Tenente Portela, Parque Estadual do Turvo, I-1990, M. Sobral et al. 6135 (F, ICN, MBM, PEL). Santa Catarina: Abelardo Luz, Rio Chapecó, 15-XI-1964, L.B. Smith \& R. Klein 13285 (HBR, F); Ibirama, posto indígena Duque de Caxias, 13-IX-1950, J.G. Kulhmann s.n. (NY634674, RB72820); Mafra, 7 km da BR 280, em direção a cidade, estrada de chão, $26^{\circ} 8.899^{\prime} \mathrm{S}, 49^{\circ} 53.544^{\prime} \mathrm{W}$, 20-X-2005, R. Lüdtke 420 (ICN); São Miguel d'Oeste, a N do Rio das Flores, 19-XII-1964, L.B. Smith \& R.M. Klein 14163 (GH, HBR); Três Barras, BR 280, $26^{\circ} 10.285^{\prime} \mathrm{S}, 50^{\circ} 16.035^{\prime} \mathrm{W}, 20-\mathrm{X}-2005$, R. Lüdtke 419 (ICN).

Polygala lancifolia ocorre no Paraguai e Brasil: Distrito Federal, Minas Gerais, Rio de Janeiro, São Paulo, Paraná, Santa Catarina e Rio Grande do Sul (Angely 1965, Wurdack \& Smith 1971, Marques 1979, 1988, Bernardi 2000, Marques \& Gomes 2002, Lüdtke \& Miotto 2004, Pastore 2006). É sempre encontrada em borda de florestas, beiras de estradas que cortam a mata e em capoeiras. Apresenta flores e frutos em todos os meses do ano.

Espécie característica pelo hábito subarbustivo alcançando até $1,56 \mathrm{~cm}$ de altura, folhas grandes, lanceoladas, cápsula alada e sementes reniformes com apêndice membranáceo-subcarnoso.

3.14. Polygala leptocaulis Torr. \& A. Gray, Fl. N. Am. 1: 130. 1838.

Figura 8a-c

Subarbustos eretos, 9,3-61 cm alt. Caule folioso, cilíndrico, fortemente estriado, glabro, sem glândulas, com ramificação basal, mediana ou terminal. Folhas pecioladas, alternas, papiráceas, glabras, glandulosas, estreito-lineares, lâminas 3-40 $\times 0,3-1,5 \mathrm{~mm}$, ápice acuminado, base atenuada, margem lisa; pecíolo 0,4-0,7 mm compr. Brácteas e bractéolas decíduas, margem lisa. Racemos pedunculados, terminais, estreito-cilíndricos, $1-21 \mathrm{~cm}$ compr., densifloros. Flores 1,8-2,1 mm compr., brancas, rosadas a roxas; pedicelos $0,6-1 \mathrm{~mm}$ compr., glabros, reflexos na frutificação. Sépalas externas glabras, glandulosas, ápice agudo, margem serreada; uma sépala largo-ovada, 0,8-1,2 mm compr.; duas sépalas livres e iguais entre si, estreito-ovadas, 0,7-1 mm compr.; sépalas internas glabras, sem glândulas, elípticas a largo-elípticas, 1,8-2 mm compr., ápice arredondado, base unguiculada. Pétalas laterais glabras, sem glândulas, estreito-elípticas a elípticas, 

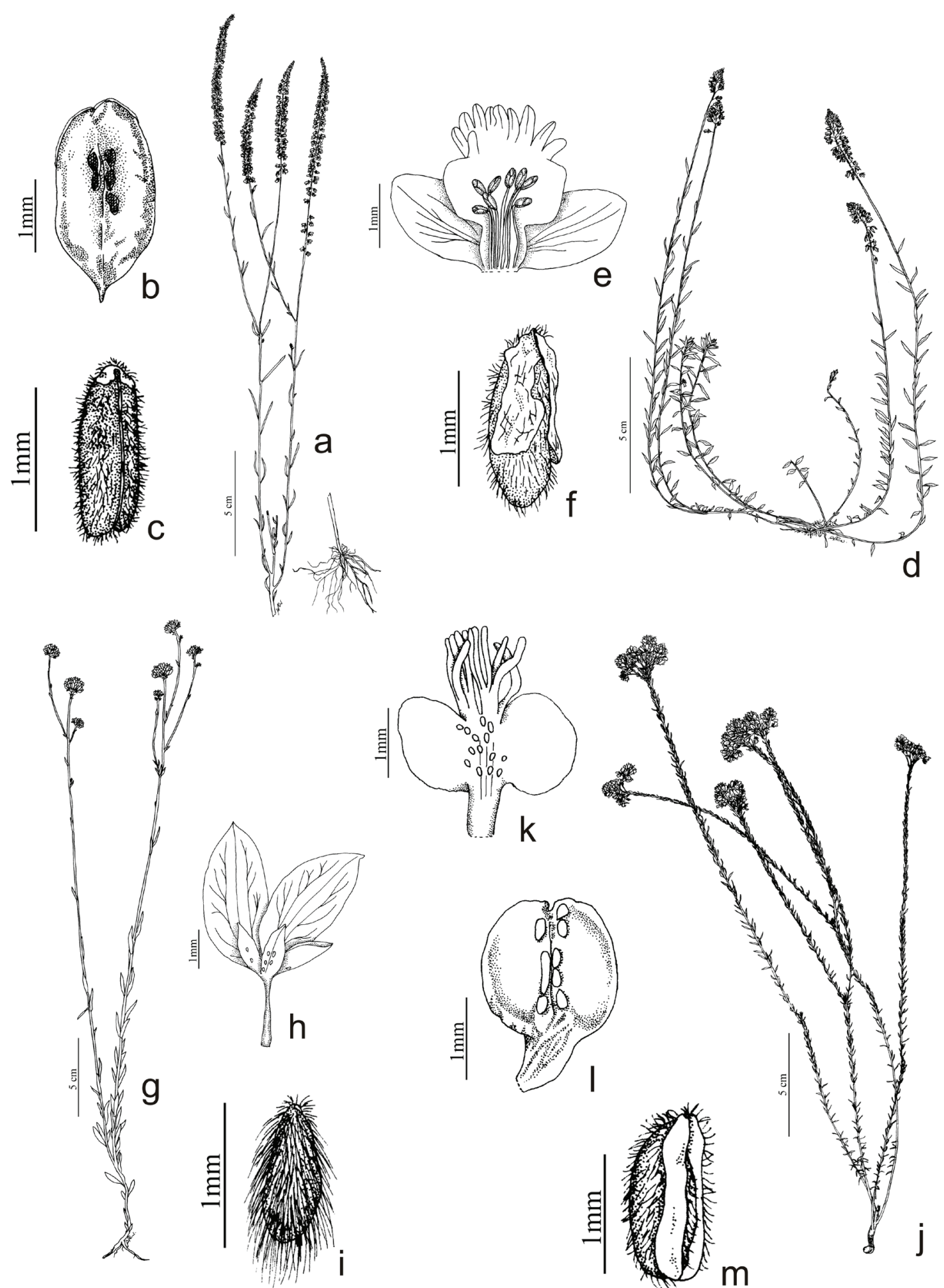

Figura 8. a-c. Polygala leptocaulis. a. Hábito. b. Fruto. c. Semente. d-f. Polygala linoides. d. Hábito. e. Corola e androceu em secção longitudinal. f. Semente. g-i. Polygala longicaulis. g. Hábito. h. Cálice. i. Semente. j-m. Polygala lycopodioides. j. Hábito. k. Carena em vista dorsal. 1. Fruto. m. Semente. [a: Malme 338B (S); b-c: Lüdtke 136 (ICN); d-f: Lüdtke 29 (ICN); g-h: Malme 618B (S); i: Rambo 34693 (PACA); j-m: Hatschbach 11662 (MBM)].

Figure 8. a-c. Polygala leptocaulis. a. Habit. b. Fruit. c. Seed. d-f. Polygala linoides. d. Habit. e. Corolla and androecium in longitudinal section. f. Seed. g-i. Polygala longicaulis. g. Habit. h. Calyx. i. Seed. j-m. Polygala lycopodioides. j. Habit. k. Carina in dorsal view. 1. Fruit. m. Seed. [a: Malme 338B (S); b-c: Lüdtke 136 (ICN); d-f: Lüdtke 29 (ICN); g-h: Malme $618 B$ (S); i: Rambo 34693 (PACA); j-m: Hatschbach $11662(\mathrm{MBM})]$. 
1,5-1,8 mm compr., ápice obtuso; carena cristada, glandulosas no dorso, crista $0,4-0,7 \mathrm{~mm}$ compr., com 6-8 lobos simples. Ovário glabro, glanduloso, elíptico. Cápsulas glabras, glandulosas, elípticas, 1,5-2 mm compr., não estipitadas, aladas, emarginadas nos dois bordos. Sementes pubérulas, ovoides, 1-1,5 mm compr., com apêndice membranáceo profundamente bilobado, atingindo 1/10 do comprimento da semente.

Material selecionado: BRASIL. ParanÁ: Guaíra, Sete Quedas, 9-VII-1950, L. Camargo s.n. (MBM2448742); Guarapuava, Fazenda Campo Real, 35 km W de Guarapuava, 21-X-1966, J.C. Lindeman \& J.H. Haas 2775 (NY); Guaraqueçaba, 24-IV-1980, L.T. Dombrowski 10386 (MBM); Guaratuba, 31-XII-1911, P. Dusén 13776 (S); Matinhos (Paranaguá), 5-VII-1947, G. Hatschbach 736 (MBM); Paranaguá, Ilha do Mel, Morro do Joaquim, 27-III-1986, S.M. Silva \& R.M. Britez s.n. (MBM244762, UEC51593); Porto Rico, Barra Nova, 9-VI-1989, S.F. Lolis 45 (HUEM, ICN); Tibagi, 17-I-1909, P. Dusén 7538 (S). Rio Grande do Sul: Cachoeira do Sul, BR 509, km 183, 30-XI-1987, O. Bueno 5095 (HAS); Canoas, 20-XI-1901, G.A. Malme 637 (S); Capão Novo, Avenida Paraguassú, 16-I-2003, R. Lüdtke 178 (ICN); Cristal, BR 116, km 435, 26-I-2005, R. Lüdtke 397 (ICN); Eldorado do Sul, Estação Agronômica da UFRGS, 22-I-2003, R. Lüdtke 188 (ICN); Mostardas, Caieiras, 13-II-1991, J.A. Jarenkow 1841 (PEL); Quaraí, Fazenda do Jarau, I-1945, B. Rambo 26196 (PACA); Rio Grande, Ilha dos Marinheiros, 25-I-2005, R. Lüdtke 391 (ICN); Santana do Livramento, na estrada de acesso ao Cerro Palomas, 9-I-2003, R. Lüdtke 136 (ICN); Vacaria, 14-IX-1970, A. Pott 105 (BLA). Santa Catarina: Araranguá, Arroio do Silva, 19-II-1955, B. Rambo 56835 (HBR, PACA); Florianópolis, SC 401, em direção ao N da Ilha, 28-XI-2006, R. Lüdtke 660 (ICN); Imbituba, Balneário Itapirubá, 9-II-1984, G. Hatschbach \& E. Zardini 47598 (MBM, NY, RB); Laguna, Farol Santa Mart, 9-V-1982, G. Hatschbach 44892 (MBM, RB).

Polygala leptocaulis ocorre nos Estados Unidos, Cuba, Colômbia, Bolívia, Argentina, Uruguai e Brasil: Distrito Federal, Rio de Janeiro, São Paulo, Paraná, Santa Catarina e Rio Grande do Sul (Herter 1956, Wurdack \& Smith 1971, Marques 1988, Marques \& Gomes 2002, Lüdtke \& Miotto 2004). Espécie abundante no litoral, em antedunas e em ambientes ruderais arenosos, restingas úmidas, em depressões brejosas, solos arenosos, campos graminosos úmidos, campos arbustivos e beiras de estradas. Floresce e frutifica em todos os meses do ano.

O diminuto tamanho do apêndice membranáceo bilobado da semente (1/10 do seu comprimento) é a característica diagnóstica e exclusiva desta espécie.

3.15. Polygala linoides Poir., Encycl. 5: 499. 1804. Figura 8d-f

Ervas eretas, 13,5-46,5 $\mathrm{cm}$ alt. Caule folioso, cilíndrico, fortemente estriado ou anguloso, escassamente piloso, com tricomas curtos, sem glândulas, simples ou com ramificação basal, mediana ou terminal. Folhas sésseis, alternas, membranáceas a papiráceas, glabras ou pilosas, sem glândulas, lineares, estreito-obovadas, obovadas, ovado-lanceoladas a elípticas, lâminas 2-20 × 1-3 mm, ápice mucronado, agudo, acuminado ou cuspidado, base aguda, obtusa ou atenuada, margem lisa ou serreada, ciliada. Brácteas e bractéolas decíduas, margem lisa. Racemos pedunculados, terminais, cilíndricos, 1-11 cm compr., laxifloros. Flores 2,5-3,5 mm compr., rosadas, lilases, roxas ou azuis; pedicelos 1-2 mm compr., glabros, patentes ou reflexos na frutificação. Sépalas externas glabras, sem glândulas, ápice obtuso ou agudo, margem inteira; uma sépala ovado-elíptica ou ovado-oblonga, 1,3-2 mm compr.; duas sépalas livres e iguais entre si, elípticas ou ovado-elípticas, 1,1-1,6 mm compr.; sépalas internas glabras, sem glândulas, elípticas, largo-elípticas ou elíptico-orbiculares, 2,3-3,7 mm compr., ápice obtuso, arredondado, base atenuada ou unguiculada. Pétalas laterais glabras, sem glândulas, elípticas, 1,9-2,8 mm compr., ápice obtuso; carena cristada, sem glândulas, crista 1-1,5 mm compr., com 6-8 lobos simples ou bífidos. Ovário glabro, sem glândulas, elíptico. Cápsulas glabras, sem glândulas, elípticas ou largo-elípticas, 1,3-2 mm compr., não estipitadas, não aladas. Sementes pubérulas, elipsoides, 1,2-2 mm compr., com apêndice membranáceo profundamente bilobado, atingindo de $1 / 2$ ao comprimento total da semente.

Material selecionado: BRASIL. PARANÁ: Campina Grande do Sul, Serra Ibitiraquire, trilha para o Pico Caratuva, 10-IV-2006, O.S. Ribas et al. 7213 (MBM); Clevelândia, Fazenda Brandalize, 1-V-1966, J.C. Lindeman \& J.H. Haas 1130 (MBM); Curitiba, s.d., M. Franck s.n. (ICN35198); Guarapuava, Cantagalo, 4-XI-1967, J.C. Lindeman \& J.H. Haas 2806 (MBM); Guaratuba, Serra de Araçatuba, 
19-VI-1960, G. Hatschbach 7077 (MBM); Laranjeiras do Sul, 4-XI-1966, J.C. Lindeman \& J.H. Haas 2806 (U); Quatro Barras, Rio Pinhal, 17-VIII-1992, C.B. Poliquesi \& J. Cordeiro 134 (MBM). Rio Grande do Sul: Bom Jesus, próximo a Serra da Rocinha, 5-II-1985, N. Silveira \& R. Frosi 1987 (HAS); Cambará do Sul, Itaimbezinho, na trilha do Cotovelo, 9-X-2004, R. Lüdtke 234 (ICN); Itaara (Santa Maria), Reserva Biológica do Ibicuí-Mirim, Campo dos Barcelos, 3-X-1989, N. Silveira 6904 (HAS); Lavras do Sul, Fazenda do Posto, 16-X-1971, J.C. Lindeman \& B.E. Irgang s.n. (U18978); São Francisco de Paula, RS 020, km 107, 15-I-2003, R. Lüdtke 158 (ICN); São José dos Ausentes, Pico do Montenegro, 14-I-2001, S.T.S. Miotto 1928 (ICN). Santa Catarina: Bom Jardim da Serra, SC 438, Serra do Rio do Rastro, 28 $24^{\prime} 03,7^{\prime \prime} \mathrm{S}, 4^{\circ} 33^{\prime} 04,4^{\prime \prime} \mathrm{W}$, 9-I-2006, R. Lüdtke 491 (ICN); Bom Retiro, BR 282,

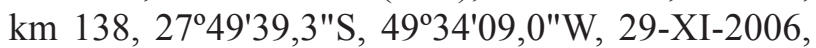
R. Lüdtke 669 (ICN); Jacinto Machado (Araranguá), Serra da Pedra, 30-XII-1943, R. Reitz 292 (RB); São Joaquim, Serra do Oratório, 14-XII-1967, A. Lourteig 2140 (HBR); Urubici, Campo dos Padres, campo do primeiro platô do Morro da Boa Vista, 27⒌ $56^{\prime} 39^{\prime \prime}$, 49²0'47"W, 8-III-2006, A. Zanin et al. 899 (ICN).

Polygala linoides ocorre no Paraguai, Uruguai, Argentina e Brasil: Minas Gerais, São Paulo, Paraná, Santa Catarina e Rio Grande do Sul (Grondona 1948, Wurdack \& Smith 1971, Marques 1979, 1988, Bernardi 2000, Lüdtke \& Miotto 2004). É abundantemente encontrada em banhados e turfeiras dos campos de altitude, campos graminosos que rodeiam os banhados, campos secos, beira de estradas, beira de matas. Floresce e frutifica em todos os meses do ano.

Assemelha-se à Polygala pulchella, porém, em $P$. linoides o hábito é sempre ereto, com caule esparsamente folioso, além de ter a carena dividida em um número maior de lobos (6-8) que podem ser simples ou bífidos, enquanto em $P$. pulchella são sempre simples. Além disso, P. pulchella possui flores brancas ou com manchas roxas e ocorre em ambientes comumente alterados, enquanto em $P$. linoides as flores são rosadas a azuis.

3.16. Polygala longicaulis Kunth, Nov. Gen. Sp. 5: 396. 1821.

Figura 8g-i

Ervas ou subarbustos eretos, 17,5-58 $\mathrm{cm}$ alt. Caule folioso, anguloso, glabro ou escassamente piloso, com tricomas curtos, sem glândulas, simples ou com ramificação mediana ou terminal. Folhas sésseis, alternas ou 4-5 verticiladas na base e alternas no ápice do ramo, papiráceas, glabras, glandulosas, lineares, elípticas ou largo-elípticas, obovadas ou oblongas, lâminas 3-29 × 0,3-6 mm, ápice mucronado, obtuso, agudo, apiculado ou acuminado, base atenuada ou cuneada, margem lisa. Brácteas e bractéolas tardiamente decíduas, margem lisa ou ciliada. Racemos pedunculados, terminais, capitados ou curto-cilíndricos, 0,5-5,5 cm compr., densifloros. Flores 3-5 $\mathrm{mm}$ compr., rosadas ou purpúreas; pedicelos 2-3 mm compr., glabros, eretos na frutificação. Sépalas externas glabras, glandulosas, ápice agudo ou acuminado, margem inteira; uma sépala ovada, 1,5-2 mm compr.; duas sépalas livres e iguais entre si, ovadas, 1-1,5 mm compr.; sépalas internas glabras, sem glândulas, elípticas, oblongas ou oblongo-elípticas, 3,5-5 mm compr., ápice agudo ou apiculado, base cuneada. Pétalas laterais glabras, sem glândulas, estreito-elípticas ou elípticas, 2,9-3,7 mm compr., ápice obtuso ou agudo, carena cristada, glandulosa no dorso, crista $0,5-0,9 \mathrm{~mm}$ compr., com 6-8 lobos simples. Ovário glabro, glanduloso, elíptico. Cápsulas glabras, glandulosas, elípticas ou oblongas, 3-4 mm compr., não estipitadas, aladas, emarginadas em um dos bordos. Sementes densamente pubescentes, com tricomas seríceos longos, prateados, cônicas, 1,2-1,5 mm compr., sem apêndice membranáceo.

Material selecionado: BRASIL. PARANÁ: Arapoti, Fazenda Araporanga, 10-II-1997, O.S. Ribas \& L.B.S. Pereira 1688 (MBM); Araucária, 25-III-1951, L. Camargo s.n. (MBM244809); Guarapuava, estrada para Palmeirinha, 15-II-1963, G. Hatschbach 9904 (MBM); Jaguaraíva, Parque Estadual do Cerrado, perto da sede, $24^{\circ} 12^{\prime} 38,2^{\prime \prime} \mathrm{S}, 49^{\circ} 41^{\prime} 04,3^{\prime \prime} \mathrm{W}, 10-\mathrm{I}-2007$, R. Lüdtke 723 (ICN); Monte Alegre, Cidade Nova, 13-XII-1951, A. Mattos s.n. (MBM244808); Palmeira, Recanto dos Papagaios; BR 277, km 144, 2527'59,3"S, 4946'05,1"W, 22-II-2006 R. Lüdtke 530 (ICN); Rio Negro, BR 116, a $5 \mathrm{~km}$ da divisa do PR com SC, 260.'33,3"S, 49²4'50,1"W, 22-II-2006, R. Lüdtke 521 (ICN); São José dos Pinhais, BR 277, km 55

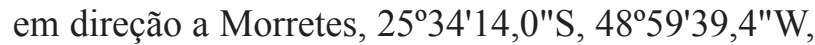
24-II-2006, R. Lüdtke 542 (ICN). Rio Grande Do Sul: Bom Jesus, Fazenda Bernardo Velho, 1-I-1947, B. Rambo 34693 (NY, PACA); Cachoeira do Sul, 21-II-1893, G.A. Malme 618B (S); São Gabriel, Caeboaté, 10-III-2002, S.A.L. Bordignon et al. 2495 (HERULBRA); Tupanciretã, 28-I-1942, B. Rambo 
9640 (LIL, PACA, SP); Vacaria, Fazenda da Ronda, 30-XII-1946, B. Rambo 34693 (PACA, S). SANTA Catarina: Campo Êre (Chapecó), Fazenda Campo São Vicente, 24 km W de Campo Erê, 28-XII-1956, L.B. Smith et al. 9422 (HBR, NY); Mafra, BR 116, próximo a ponte Rio da Lança, $26^{\circ} 07^{\prime} 45,4^{\prime \prime} \mathrm{S}$, 4947'51,9"W, 22-II-2006, R. Lüdtke 520 (ICN).

Polygala longicaulis tem ampla distribuição ocorrendo do México ao Paraguai, Argentina, Colômbia e Brasil: Roraima, Amapá, Rio Grande do Norte, Paraíba, Piauí, Bahia, Mato Grosso, Goiás, Distrito Federal, Minas Gerais, São Paulo, Paraná, Santa Catarina e Rio Grande do Sul (Grondona 1948, Wurdack \& Smith 1971, Marques 1979, 1988, Bernardi 2000, Marques \& Gomes 2002, Lüdtke \& Miotto 2004). Pode ser encontrada em campos úmidos, graminosos, orlas de matas e brejos. Segundo Wurdack $\&$ Smith (1971) desenvolve-se preferencialmente em campos úmidos e limpos, em solos pedregosos e nos banhados rasos. Floresce e frutifica de setembro a junho.

Caracteriza-se pelas sementes sem apêndices, geralmente de forma cônica e com tricomas longos, seríceos e prateados. As inflorescências são inicialmente cilíndricas, mas com a queda das flores mais velhas tornam-se capitadas, restando as cicatrizes evidentes dos pedicelos.

3.17. Polygala lycopodioides Chodat, Mém. Soc. Phys. Genève 31(2): 252. 1893.

= Polygala dusenii Norl. Repert. Spec. Nov. Regni Veg. 13: 402. 1914.

Figura $8 \mathrm{j}-\mathrm{m}$

Subarbustos eretos, $19-73 \mathrm{~cm}$ alt. Caule folioso, cilíndrico, estriado, pubérulo, sem glândulas, com intensa ramificação basal. Folhas numerosas, sésseis, alternas, adpressas ao caule, cartáceas, glabras, glandulosas ou não, ovadas a lanceoladas, lâminas 2-9 $\times$ 0,5-1 mm, ápice agudo ou acuminado, base obtusa, margem inteira, ciliada. Brácteas e bractéolas tardiamente decíduas, margem lisa. Racemos pedunculados, terminais, curto-cilíndricos a globosos, 0,3-1,5 cm compr., densifloros. Flores 3-4,1 mm compr., rosadas, lilases, roxas, pedicelos $0,8-2 \mathrm{~mm}$ compr., glabros, eretos ou patentes na frutificação. Sépalas externas glabras, glandulosas, ápice agudo, margem lisa; uma sépala ovado-côncava a rômbica, 1,5-1,8 mm compr.; duas sépalas livres e iguais entre si, ovadas, 1,1-1,5 mm compr.; sépalas internas glabras, glandulosas ou não, elípticas ou obovadas,
3,1-4 mm compr., ápice obtuso, agudo, arredondado ou apiculado, base atenuada a unguiculada. Pétalas laterais glabras, sem glândulas, elípticas a rômbicas, 2,4-3,5 mm compr., com ápice arredondado; carena cristada, glandulosa no dorso, crista com 0,8-1,2 mm compr., com 6-8 lobos simples e bífidos. Ovário glabro, glanduloso, elíptico a largo-elíptico. Cápsulas glabras, glandulosas, largo-elípticas a orbiculares, 1,7-2,8 mm compr., longo-estipitadas, não aladas. Sementes pubescentes, elipsoides ou ovoides, 1,2-1,5 mm compr., com apêndice membranáceo totalmente bilobado, atingindo $1 / 2$ ou ultrapassando o comprimento da semente.

Material selecionado: BRASIL. PARANÁ: Castro, Rio São João, 3-X-1964, G. Hatschbach 11662 (F, HBR, MBM, PEL, U); Palmeira, Rodovia do Café, margem esquerda do Rio Tibagi, E.K. Takahashi et al. 19 (FUEL); Ponta Grossa, Parque Estadual Vila Velha, 25-I-1910, P. Dusén 9106 (S); Tibagi, Parque Estadual do Guartelá, Cânion Rio Iapó, Lajeado do Pedregulho, 10-XI-1992, G. Hatschbach \& E. Barbosa 58200 (MBM).

Polygala lycopodioides ocorre no Brasil: São Paulo e Paraná (Angely 1965, Marques 1988, Bernardi 2000, Marques \& Gomes 2002). É encontrada em campos secos ou úmidos, em afloramentos rochosos, solos arenosos e organossolos. Floresce e frutifica em todos os meses do ano.

Polygala lycopodioides é facilmente reconhecida pelas numerosas folhas sésseis, adpressas ao caule, cartáceas e pelos racemos geralmente capitados. Apresenta glândulas nos verticilos florais e nas partes reprodutivas.

Bernardi (2000) sinonimizou Polygala dusenii com $P$. lycopodioides e citou esta espécie para o Estado do Paraná. Tanto $P$. dusenii quanto $P$. lycopodioides foram citadas por Marques (1988) e Marques \& Gomes (2002) para o referido Estado. A cuidadosa análise dos espécimes-tipo de ambos os táxons e do material de herbário disponível, permite aceitar a sinonimização feita por Bernardi (2000), confirmando, portanto, a ocorrência de $P$. lycopodioides para a região Sul do Brasil.

3.18. Polygala molluginifolia A. St.-Hil. \& Moq., Mém. Mus. Hist. Nat. 17: 349. 1828.

Figura 9a-e

Ervas eretas, $10-43 \mathrm{~cm}$ alt. Caule folioso, quadrangular ou anguloso, glabro, sem glândulas, 
simples ou com ramificação basal, mediana ou terminal. Folhas sésseis, 4-5 verticiladas na base e alternas no ápice do ramo, papiráceas, glabras, glandulosas, lineares a linear-elípticas ou obovadas, lâminas 7-43 × 1-5 mm, ápice apiculado ou acuminado, base atenuada, margem denticulada, lisa. Brácteas e bractéolas decíduas, margem lisa ou ciliada. Racemos pedunculados, terminais, cilíndricos, 2-18 cm compr., laxifloros. Flores 2-3,3 mm compr., rosadas, lilases ou magenta; pedicelos 0,5-1,7 mm compr., glabros, reflexos na frutificação. Sépalas externas glabras, glandulosas, ápice acuminado, margem ciliada; uma sépala ovada, 1,3-2,2 mm compr.; duas sépalas livres e iguais entre si, elíptico-lanceoladas, 1-2 mm compr.; sépalas internas glabras, elípticas, 2-4 mm compr., ápice obtuso, base unguiculada. Pétalas laterais glabras, com ou sem glândulas, elípticas, 2-3,5 mm compr., ápice obtuso; carena cristada, glandulosa, crista 0,6-1 mm compr., com 6-8 lobos simples. Ovário glabro, glanduloso, elíptico ou orbicular. Cápsulas glabras, glandulosas, elípticas ou elípticooblongas, 1,6-2 mm compr., não estipitadas, não aladas. Sementes pubescentes, elipsoides ou ovoides, 1,6-2,1 mm compr., com apêndice membranáceo profundamente bilobado, atingindo de $2 / 3$ a $3 / 4$ do comprimento da semente.

Material selecionado: BRASIL. Paraná: Balsa Nova, Ponte dos Arcos, 3-VI-2005, C. Kozera \& R. Kersten 2202 (MBM); Castro, estrada do Cerne, km 116-117, 9-I-1947, G. Hatschbach 591 (MBM, RB); Guarapuava, Fazenda 3 Capões, 16-XII-1965, R. Reitz \& R. Klein 17757 (GH, HBR, NY); Jaguariaíva, PR 151, Rio das Mortes, 24²12'22,9"S, 49³9'17,3"W, 10-I-2007, R. Lüdtke 737 (ICN); Palmeira, BR 277, no trevo com a PR $151, \mathrm{~km} 169,25^{\circ} 26^{\prime} 01,9^{\prime \prime} \mathrm{S}$, 4959'50,5"W, 7-XI-2007, R. Lüdtke 796 (ICN); Ponta Grossa, Desvio Ribas, 20-X-1914, P. Dusén 15664 (S); Sengés, Rod. Jaguariaíva, 20-XII-1961, G. Hatschbach 8730 (MBM). Rio Grande do Sul: Alegrete, BR 290, km 612, 28-XII-2004, R. Lüdtke 377 (ICN); Arroio Grande, BR 116, km 585, 32 $03^{\circ} 40,3^{\prime \prime S}$, 52'52'21,4"W, 31-X-2006, R. Lüdtke 623 (ICN); Cacequi, RS 640, km 02, 29-XII-2004, R. Lüdtke 383 (ICN); Cachoeira do Sul, BR 290, km 289, 11-I-2002, S.T.S. Miotto 1997 (ICN); Capão do Leão, BR 116,

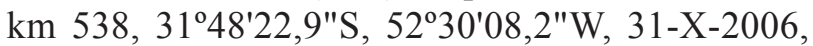
R. Lüdtke 612 (ICN); Cruz Alta, BR 158, a 4,5 km do trevo de Cruz Alta, 21-XI-2002, R. Lüdtke 67 (ICN); Itaqui, BR 472, km 507, 13-I-2002, S.T.S. Miotto 2023 (ICN); Jaguarão, BR 116, km 652, 32³1'28,2"S,
52²0'49,4"W, 31-X-2006, R. Lüdtke 631 (ICN); Santo Antônio das Missões, BR 285 a 60 km de São Borja, 20-XI-2002, R. Lüdtke 64 (ICN); São Borja, Arroio Butuí, BR 472, km 429, 13-I-2002, S.T.S. Miotto 2024 (ICN).

Polygala molluginifolia ocorre no Uruguai, Argentina, Paraguai e Brasil: São Paulo, Paraná e Rio Grande do Sul (Grondona 1948, Angely 1965, Wurdack \& Smith 1971, Marques 1988, Bernardi 2000, Marques \& Gomes 2002, Lüdtke \& Miotto 2004). Esta espécie nunca foi coletada em Santa Catarina, embora seja citada por Wurdack \& Smith (1971) como de provável ocorrência nesse Estado.

Pode ser encontrada em beiras de estradas alteradas por queimadas, em baixadas úmidas, campos graminosos e arbustivos, em solos secos ou úmidos, campos pastejados secos, terrenos pedregosos, menos frequentemente em banhados e capoeiras. Floresce e frutifica durante todos os meses do ano.

Assemelha-se à Polygala adenophylla, com a qual compartilha folhas verticiladas sésseis e presença de glândulas nas estruturas vegetativas e reprodutivas, porém, em $P$. molluginifolia as brácteas e bractéolas são decíduas e as flores rosadas a magenta.

3.19. Polygala monosperma A.W. Benn., Fl. Bras. 13(3): 19. 1874.

$=P$. pseudosericea Chodat, Mém. Soc. Phys. Genève 31(2): 241. 1893.

Figura $9 \mathrm{f}-\mathrm{h}$

Subarbustos eretos, 45-60 cm alt. Caule áfilo ou subáfilo, cilíndrico, anguloso, glabro, sem glândulas, com ramificação terminal. Folhas decíduas, sésseis, alternas, membranáceas, glabras, sem glândulas, escamiformes, lâminas $2 \times 1 \mathrm{~mm}$, ápice agudo, base obtusa, margem inteira, lisa. Brácteas e bractéolas decíduas, margem lisa ou ciliada. Racemos pedunculados, terminais, cilíndricos, $5-15 \mathrm{~cm}$ compr., densifloros. Flores 3-3,5 mm compr., lilases, pedicelos 0,8-1 mm compr., glabros, reflexos na frutificação. Sépalas externas glabras, sem glândulas, ápice agudo, margem lisa; uma sépala ovada, 1,2-1,8 mm compr.; duas sépalas livres e iguais entre si, ovadas, 1-1,2 mm compr.; sépalas internas glabras, sem glândulas, obovadas ou espatuladas, $2 \mathrm{~mm}$ compr., ápice arredondado, base atenuada ou cuneada. Pétalas laterais glabras, sem glândulas, elíptico-romboidais, 2,7-2,9 mm compr., ápice arredondado; carena cristada, sem glândulas, crista com 0,6-1 mm compr., com 6-7 lobos simples e bífidos. Ovário glabro, sem 

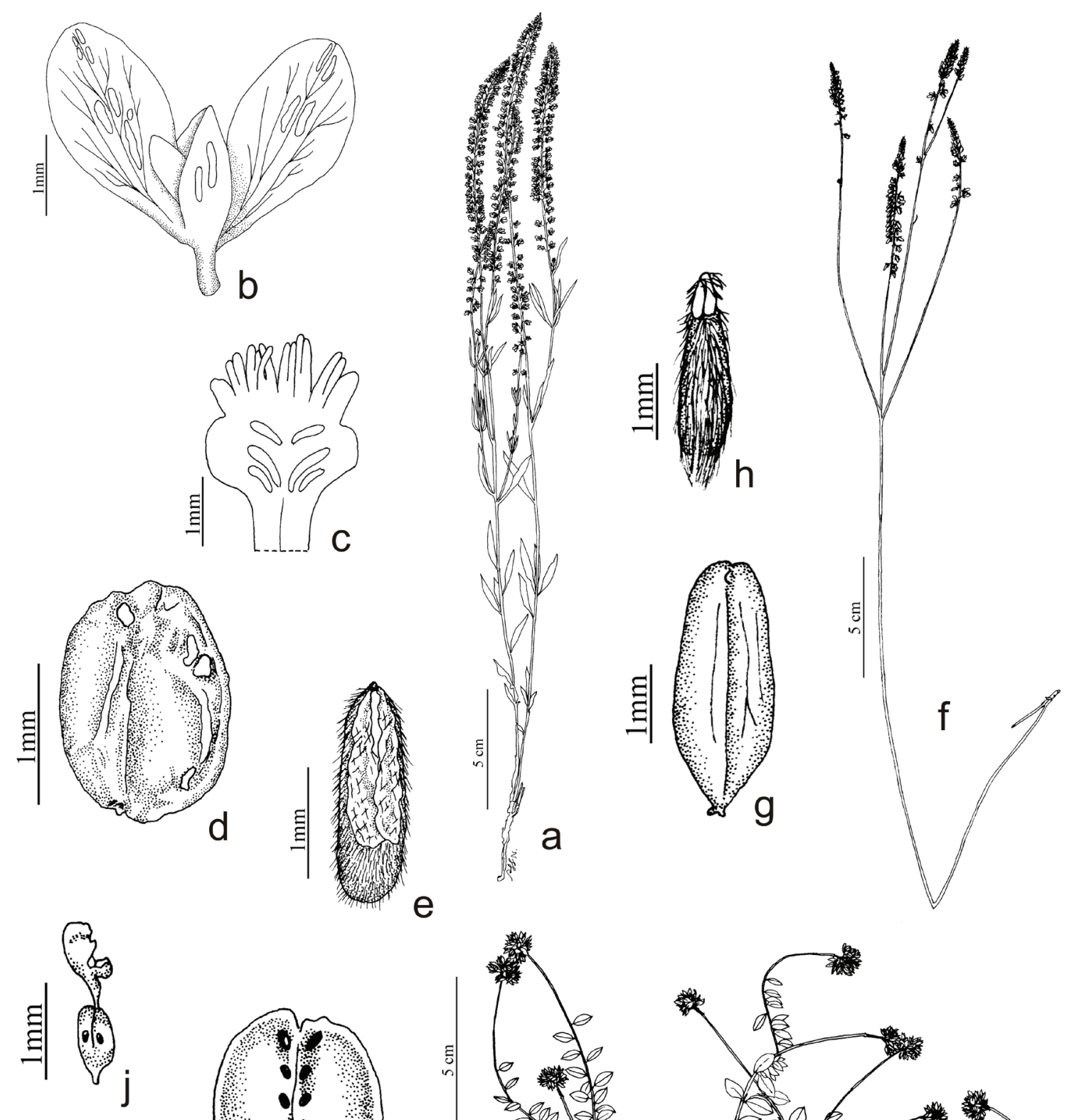

e
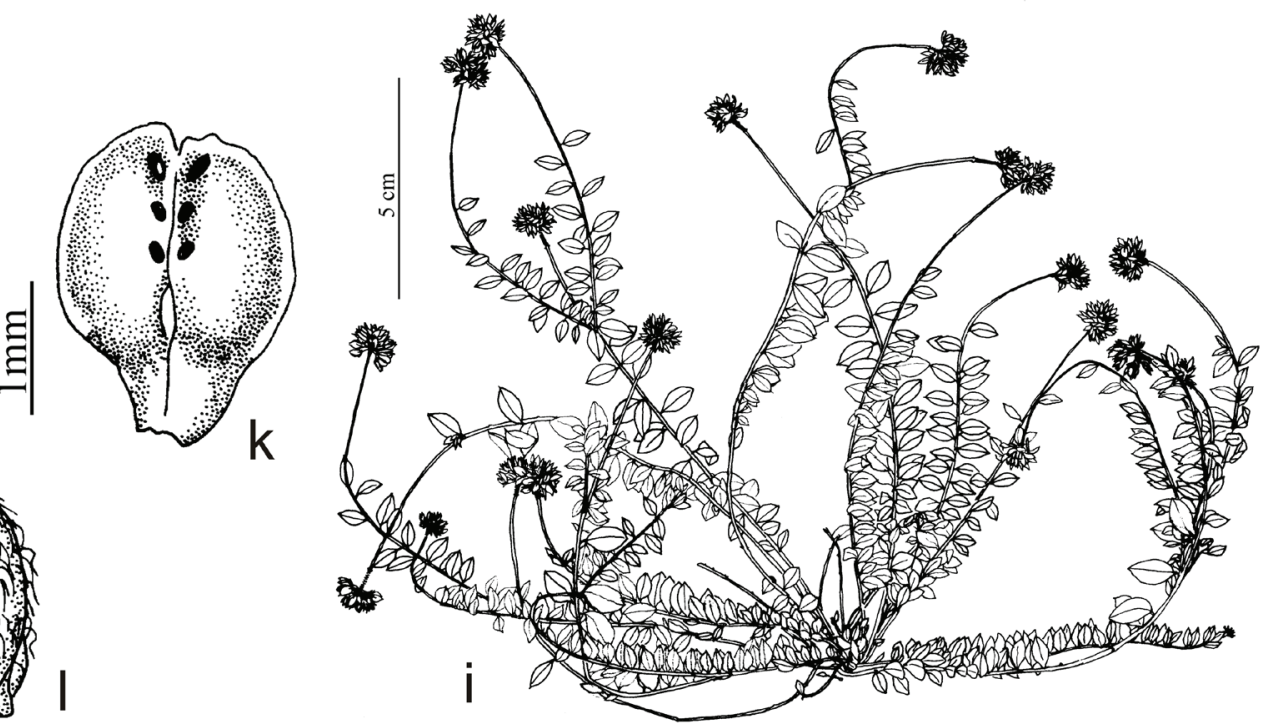

Figura 9. a-e. Polygala molluginifolia. a. Hábito. b. Cálice. c. Carena em vista dorsal. d. Fruto. e. Semente. f-h. Polygala monosperma. f. Hábito. g. Fruto. h. Semente. i-l. Polygala moquiniana. i. Hábito. j. Gineceu. k. Fruto. 1. Semente. [a-e: Lüdtke 149 (ICN); f-h: Dusén 15661 (S); i-1: Hatschbach 12269 (MBM)].

Figure 9. a-e. Polygala molluginifolia. a. Habit. b. Calyx. c. Carina in dorsal view. d. Fruit. e. Seed. f-h. Polygala monosperma. f. Habit. g. Fruit. h. Seed. i-1. Polygala moquiniana. i. Habit. j. Gynoecium. k. Fruit. 1. Seed. [a-e: Lüdtke 149 (ICN); f-h: Dusén 15661 (S); i-1: Hatschbach 12269 (MBM)]. 
glândulas, oblongo. Cápsulas glabras, sem glândulas, elípticas ou oblongas, 3,5 mm compr., não estipitadas, não aladas. Sementes pilosas, estreito-ovoides, 2-2,5 mm compr., tricomas longos ultrapassando o comprimento da semente, com apêndice membranáceo totalmente bilobado, atingindo de $1 / 5$ do comprimento da semente.

Material examinado: BRASIL. PARANÁ: Ponta Grossa, Desvio Ribas, 26-I-1910, P. Dusén 9026 (S); idem, 20-X-1914, P. Dusén 15661 (GH, S).

Polygala monosperma ocorre no Paraguai e no Brasil: Pernambuco, Bahia, Distrito Federal, Minas Gerais e Paraná (Marques 1988, Bernardi 2000). A última coleta desta espécie no Estado do Paraná foi realizada há 103 anos e durante este trabalho não houve sucesso nas tentativas de recoleta. Floresce e frutifica de outubro a janeiro.

Polygala monosperma caracteriza-se pela ausência de folhas desenvolvidas, restando apenas folhas escamiformes reduzidas o que a aproxima com $P$. aphylla. No material examinado durante o presente estudo, $P$. monosperma apresentou comumente apenas uma semente e as cápsulas observadas eram desprovidas de alas. As sementes apresentam tricomas longos que ultrapassam o comprimento da semente, e o apêndice membranáceo é pequeno alcançando apenas $1 / 5$ do comprimento da semente, enquanto que em $P$. aphylla as cápsulas são aladas, as sementes são esparsamente pubérulas ou pubescentes e o apêndice membranáceo é maior, alcançando $3 / 4$ do comprimento da semente.

Marques (1988) citou Polygala pseudosericea para o Paraná. Bernardi (2000) sinonimizou P. pseudosericea com P. monosperma. Após análise das descrições originais e dos exemplares disponíveis, percebeu-se que não há diferenças relevantes e suficientes para manter os dois táxons como espécies distintas, portanto, aceita-se a sinonimização proposta por Bernardi (2000).

3.20. Polygala moquiniana A. St.-Hil. \& Moq., Mém.

Mus. Hist. Nat 17: 326. 1828.

Figura 9i-1

Subarbustos decumbentes a prostrados (com ramos ascendentes), 8-32 $\mathrm{cm}$ alt. Caule folioso, anguloso, pubescente, tricomas curtos, clavados, sem glândulas, com intensa ramificação basal, além de mediana e terminal. Folhas numerosas, pecioladas, opostas na base e alternas no ápice da planta, patentes, cartáceas, escassamente pubescentes, glandulosas, elípticas, lâminas 3-13 × 1-4 mm, ápice agudo, acuminado, apiculado, base aguda, margem revoluta, lisa; pecíolos 0,5-1 mm compr. Brácteas e bractéolas decíduas, margem lisa. Racemos longo-pedunculados (38 mm compr.), terminais, capitados, globosos, 0,5-6 cm compr., densifloros. Flores 3-4,2 mm compr., rosadas a magenta, pedicelos 2,2-3 mm compr., glabros ou papilosos, eretos a patentes na frutificação. Sépalas externas glabras, glandulosas, ápice acuminado, margem lisa; uma sépala largoovada, 1,5-1,8 mm compr.; duas sépalas livres e iguais entre si, ovado-elípticas, 1,2-1,6 mm compr.; sépalas internas glabras, sem glândulas, elípticas, 3,2-4,1 mm compr., ápice apiculado, base atenuada. Pétalas laterais glabras, sem glândulas, elípticas, 2,4-3 mm compr., com ápice arredondado; carena cristada, glandulosa no dorso, crista com $0,8-1 \mathrm{~mm}$ compr., com 6-7 lobos simples e bífidos. Ovário glabro, glanduloso, oblongo. Cápsulas glabras, glandulosas, oblongas ou obovadas, 2-2,5 mm compr., estipitadas, aladas, emarginadas nos dois bordos; corola, estilete e estigma decíduos. Sementes densamente pilosas, ovoides, 1,3-1,6 mm compr., tricomas ondulados, com apêndice membranáceo totalmente bilobado, atingindo o comprimento da semente.

Material selecionado: BRASIL. PARANÁ: Balsa Nova, Serra de São Luis, 6-I-1971, G. Hatschbach 2543 (MBM, RB); Carambeí, 25-XII-1910, P. Dusén 11297 (BM, GH, NY, S); Clevelândia, Fazenda Brandalize, 29 km de Clevelândia, 1-V-1966, J.C. Lindeman \& J.H. Haas 1121 (MBM, RB, U); Guarapuava, Três Capões, 8-XII-1982, G. Hatschbach 45802 (MBM, RB); Jaguariaíva, Fazenda Cajurú, Rio Cajurú, $24^{\circ} 10^{\prime} \mathrm{S}, 49^{\circ} 19^{\prime} \mathrm{W}, 18-\mathrm{I}-1965$, L.B. Smith et al. 14784 (GH, NY); Lapa, Rio Capivari, próximo a barra com o Rio Iguaçu, 7-III-2002, O.S. Ribas et al. 4552 (MBM); Marmeleiro, na estrada de Marmeleiro a Campo Erê, 25-X-1970, G. Hatschbach 22650 (NY); Palmas, S. Agostinho, 13-XII-1966, G. Hatschbach 15401 (MBM); Palmeira, BR 277, no trevo com a PR 151, km 169, 252 26'01,9"S, 4959'50,5"W, 7-XI-2007, R. Lüdtke 795 (ICN); Piraí do Sul, Joaquim Murtinho, 18-XI-1976, G. Hatschbach 39192 (MBM, NY); Ponta Grossa, estrada para Palmeira, $25^{\circ} 15^{\prime} 32,0^{\prime \prime} \mathrm{S}$, 5008'54,3"W, 11-I-2007, R. Lüdtke 749 (ICN); São Luis do Purunã (Campo Largo), Tamanduá, 9-XI-1978, L.T. Dombrowski 9963 (MBM). SANTA CAtarina: Araranguá, Serra da Pedra, 28-XII-1943, R. Reitz 335 (GH); Campo Erê, 8 km oeste de Campo 
Erê, 7-XII-1964, L.B. Smith \& R. Klein 13763 (HBR, GH, NY); São Joaquim, Varginha, 15-I-1956, J. Mattos 2802 (HAS); idem, 25-I-1956, J. Mattos 3588 (HAS).

Polygala moquiniana ocorre no Brasil: São Paulo, Paraná e Santa Catarina (Angely 1965, Marques 1988, Bernardi 2000, Marques \& Gomes 2002). Pode ser encontrada em campos limpos, secos ou úmidos, pedregosos, solos arenosos, junto a afloramentos rochosos e em locais antropizados. Floresce e frutifica em todos os meses do ano.

Esta espécie é facilmente identificada devido a caracteres exclusivos como os longos pedúnculos que sustentam as inflorescências, com até $38 \mathrm{~mm}$ de comprimento e tricomas ondulados na semente. Polygala altomontana pode ser confundida com P. moquiniana, especialmente pelo hábito e por ambas apresentarem corola persistente no fruto, porém, em $P$. altomontana, o estigma e o estilete também persistem no fruto enquanto que em $P$. moquiniana estas estruturas são decíduas.

3.21. Polygala obovata A. St.-Hil. \& Moq., Ann. Soc. Sci. Orléans 9: 52. 1828. Figura 10a-d

Subarbustos cespitosos, $17-18 \mathrm{~cm}$ alt. Caule folioso, cilíndrico, fortemente estriado ou anguloso, densamente piloso, com tricomas curtos, sem glândulas, com ramificação basal, mediana ou terminal. Folhas pecioladas, alternas, cartáceas, pilosas, glandulosas, ovado-elípticas ou elípticas, lâminas 3-5 × 1-2 mm, ápice agudo ou acuminado, base obtusa ou atenuada, margem irregular, lisa; pecíolos 0,3-0,4 mm compr. Brácteas e bractéolas tardiamente decíduas, margem ciliada. Racemos pedunculados, terminais, subcapitados ou curto-cilíndricos, 0,7-1,6 cm compr., laxifloros ou densifloros. Flores 3-4 mm compr., lilases; pedicelos 0,5-2 mm compr., glabros, eretos a reflexos na frutificação. Sépalas externas glabras, glandulosas, ápice agudo ou cuspidado, margem ciliada; uma sépala ovado-elíptica, 1,7-1,9 mm compr.; duas sépalas livres e iguais entre si, ovadas, 1-1,5 mm compr.; sépalas internas glabras, glandulosas na base, elípticas, 3-4 mm compr., ápice cuspidado, base atenuada ou obtusa. Pétalas laterais glabras, glandulosas, elípticas, 2,1-3 mm compr., ápice obtuso; carena cristada, glandulosa, crista $2 \mathrm{~mm}$ compr., com 8 lobos simples ou bífidos. Ovário glabro, glanduloso, elíptico. Cápsulas glabras, glandulosas, elípticas ou elíptico-orbiculares, 2 mm compr., estipitadas, aladas, emarginadas em ambos os bordos. Sementes pubescentes, ovoides, 1,6-1,8 mm compr., com apêndice membranáceo profundamente bilobado, atingindo $1 / 4$ a $1 / 2$ do comprimento da semente.

Material examinado: BRASIL. PAranÁ: Campina Grande do Sul, Pico Camaquã, 29-IV-1970, G. Hatschbach 24217 (MBM). Rio Grande do Sul: Arroio dos Ratos, Fazenda Faxinal, X-1975, K. Hagelund 9618 (ICN); Caxias do Sul, Criúva, 17-XI-2000, L. Scur 866 (HUCS, MBM); Nova Petrópolis, 11-II-1963, A. Sehnem s.n. (PACA82073); Montenegro, CAU 5, 15-IX-1977, O. Bueno 834 (HAS); Santiago, 4-IX-2006, R. Schmidt 1519 (ICN); Vacaria, BR 116, a $20 \mathrm{~km}$ da divisa com SC, 27-XII-2002, R. Lüdtke 114 (ICN). SANTA CATARINA: Garuva (São Francisco do Sul), Monte Cristo, 6-X-1960, R. Reitz \& R. Klein 10028 (B, HBR); São Joaquim, Costa Dinheiro, $28^{\circ} 07^{\prime} \mathrm{S}, 49^{\circ} 32^{\prime} \mathrm{W}, 3-\mathrm{I}-1965$, L.B. Smith \& R. Reitz 14194 (B).

Polygala obovata ocorre no Uruguai, Paraguai, Argentina e Brasil: Bahia, São Paulo, Paraná, Santa Catarina e Rio Grande do Sul (Marques 1988, Bernardi 2000, Marques \& Gomes 2002, Lüdtke \& Miotto 2004). É encontrada em capoeiras, barrancos e margens de estradas, encostas de morros e baixadas úmidas. Floresce e frutifica de setembro a abril.

Polygala obovata apresenta hábito cespitoso, folhas alternas, ovadas, brácteas tardiamente caducas e glândulas nas folhas e peças florais. $O$ hábito e o formato das folhas lembram $P$. moquiniana, porém, $P$. obovata difere daquela pela ausência de pedúnculos longos, pela corola caduca no fruto e pela ausência de tricomas ondulados na semente.

3.22. Polygala paniculata L., Syst. Nat. ed. 10, 2: 1154. 1759.

Figura 10e-g

Ervas ou subarbustos eretos, $19-87 \mathrm{~cm}$ alt. Caule folioso, cilíndrico, levemente estriado, glanduloso, densamente piloso, com tricomas curtos, com ramificação basal, mediana ou terminal. Folhas sésseis, 4-5 verticiladas na base e alternas no ápice da planta, papiráceas, pilosas, glandulosas, lineares, estreito-elípticas a largo-elípticas, lâminas $5-35 \times 0,5-5 \mathrm{~mm}$, ápice mucronado, agudo ou acuminado, base atenuada, margem inteira ou irregular, ciliada. Brácteas e bractéolas decíduas, margem lisa. Racemos pedunculados, terminais, estreito-cilíndricos, 0,5-12 cm compr., laxifloros. Flores 2,1-2,8 mm compr., branco-rosadas, rosadas a 


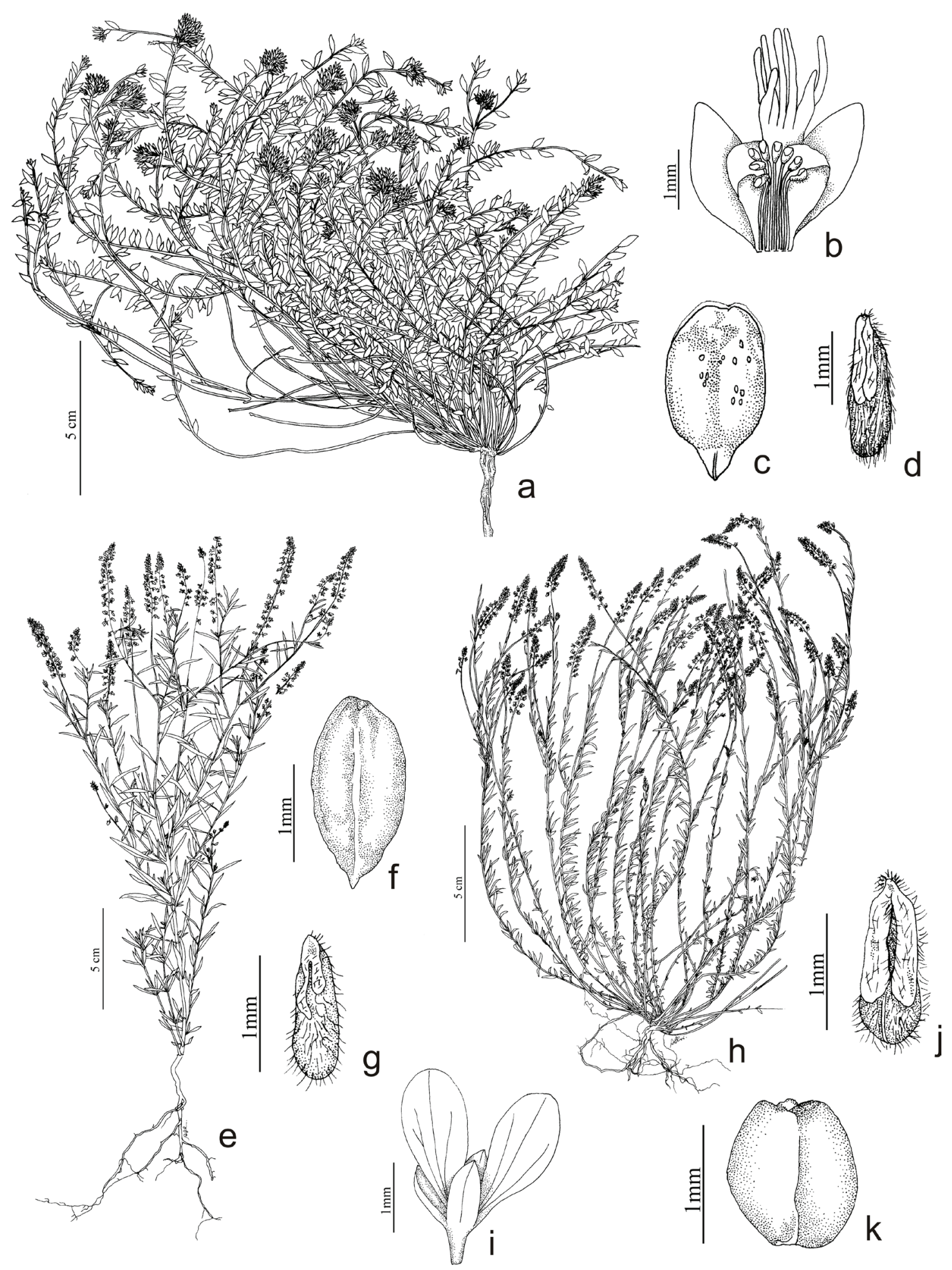

Figura 10. a-d. Polygala obovata. a. Hábito. b. Corola e androceu em secção longitudinal. c. Fruto. d. Semente. e-g. Polygala paniculata. e. Hábito. f. Fruto. g. Semente. h-k. Polygala pulchella. h. Hábito. i. Cálice. j. Semente. k. Fruto. [a-d: Hagelund 9618 (ICN); e: Sobral 3746 (MBM); f-g: Lüdtke 184 (ICN); h: Lüdtke 42 (ICN); i-k: Lüdtke 4 (ICN)].

Figure 10. a-d. Polygala obovata. a. Habit. b. Corolla and androecium in longitudinal section. c. Fruit. d. Seed. e-g. Polygala paniculata. e. Habit. f. Fruit. g. Seed. h-k. Polygala pulchella. h. Habit. i. Calyx. j. Seed. k. Fruit. [a-d: Hagelund 9618 (ICN); e: Sobral 3746 (MBM); f-g: Lüdtke 184 (ICN); h: Lüdtke 42 (ICN); i-k: Lüdtke 4 (ICN)]. 
roxas; pedicelos 0,8-1 mm compr., glabros, reflexos na frutificação. Sépalas externas glabras, glandulosas, ápice obtuso, margem inteira; uma sépala largo-ovada, 1-1,5 mm compr.; duas sépalas livres e iguais entre si, estreito-ovadas, 1-1,5 mm compr.; sépalas internas pilosas na base da face ventral, sem glândulas, elípticas, 2-2,5 mm compr., ápice obtuso, base cuneada ou atenuada. Pétalas laterais glabras, sem glândulas, estreito-elípticas, 2,1-2,5 mm compr., ápice obtuso ou arredondado; carena cristada, sem glândulas, crista 0,3-0,8 mm compr., com 6-9 lobos simples. Ovário glabro, sem glândulas, elíptico. Cápsulas glabras, sem glândulas, elípticas, 2-2,6 mm compr., não estipitadas, não aladas. Sementes pubescentes, elipsoides ou ovoides, 1,5-1,8 mm compr., com apêndice membranáceo profundamente bilobado, atingindo de $1 / 4$ a $4 / 5$ do comprimento da semente.

Material selecionado: BRASIL. PARANÁ: Antonina, em direção a São João da Graciosa, PR 410, 2525'16,8"S, 48 49'24,2"W, 8-I-2007, R. Lüdtke 713 (ICN); Barra do Saí, 21-I-1986, A. Krapovickas \& C.L. Cristóbal 40363 (GH); Guaratuba, Serra de Araçatuba, Morro dos Perdidos, 15-X-1997, E.P. Santos \& H.M. Hernandes 316 (UPCB); Jaguariaíva, PR 151, Rio das Mortes, 24¹2'22,9"S, 49³9'17,3"W, 10-I-2007, R. Lüdtke 735 (ICN); Morretes, arredores, 22-IX-1946, G. Hatschbach 378 (MBM); Quatro Barras, BR 116, 2521'31,3"S, 4904'26,3"W, 9-I-2007, R. Lüdtke 715 (ICN); Tunas do Paraná, Colônia João XXIII, 27-VI-2002, O.S. Ribas \& L.M. Abe 4721 (MBM); Xambrê, Rio Piquiri, 21-VI-1966, J.C. Lindeman \& J.H. Haas 1686 (MBM, NY, U). Rio Grande do Sul: Arroio do Sal, Rondinha Nova, 3-IX-1986, M. Bassan et al. 684 (HAS); Dom Pedro de Alcântara, BR 101, entre os km 86 e 87, 19-X-2004, R. Lüdtke 237 (ICN); Esmeralda, 14-X-1978, L. Arzivenco 313 (ICN); Osório, Lagoa dos Quadros, 21-II-1950, B. Rambo 45944 (B, PACA); Rio Grande, III-1930, N. Halmbang s.n. (S); Torres, Estrada do Mar, km 85, 16-I-2003, R. Lüdtke 170 (ICN). SANTA Catarina: Blumenau, BR 470, em direção a Rio do Sul, 26 52.997'S, $49^{\circ} 08.711^{\prime} \mathrm{W}, 22-\mathrm{X}-2005$, R. Lüdtke 424 (ICN); Corupá, BR 280, km 90, Serra do Mar, 26²3'29,6"S, $49^{\circ} 18^{\prime} 05,1^{\prime \prime W}, 22-\mathrm{II}-2006, R$. Lüdtke 516 (ICN); Garuva, Porto Palmital, 260'ㄹ' $26,9^{\prime \prime} \mathrm{S}, 48^{\circ} 50^{\prime} 00,2^{\prime \prime} \mathrm{W}$, 12-I-2006, R. Lüdtke 504 (ICN); Palhoça, Massiambú, $27^{\circ} 48^{\prime} 25,8^{\prime \prime} \mathrm{S}, 48^{\circ} 38^{\prime} 31,2^{\prime \prime} \mathrm{W}, 13-\mathrm{I}-2006$, R. Lüdtke 509 (ICN); Urussanga, SC 446, km 22, 31 $05^{\circ} 09^{\prime \prime S}$, 5342'24"W, 19-X-2004, R. Lüdtke 239 (ICN).

Polygala paniculata ocorre na Nova Guiné, Estados Unidos, México, Trinidad Tobago, República
Dominicana, Guatemala, Jamaica, Cuba, Venezuela, Bolívia, Colômbia, Equador, Peru e Brasil: Roraima, Amazonas, Mato Grosso, Pernambuco, Bahia, Goiás, Espírito Santo, Minas Gerais, Rio de Janeiro, São Paulo, Paraná, Santa Catarina e Rio Grande do Sul (Wurdack \& Smith 1971, Marques 1988, Bernardi 2000, Eriksen et al. 2000, Marques \& Gomes 2002, Lüdtke \& Miotto 2004).

Segundo Paiva (1998), Polygala paniculata é a espécie mais amplamente distribuída do gênero, originária da América tropical (Brasil e Bolívia), América Central (incluindo as ilhas do Caribe) até o México e Texas (EUA). Introduzida e naturalizada em várias ilhas da Micronésia, Polinésia, Indonésia e Malásia. É encontrada em lugares alterados, em beiras de estradas, em solos úmidos, secos, arenosos, em restingas, beiras de matas de planície, no interior e na orla de capoeiras, campos arbustivos e, mais raramente, em banhados. É considerada, frequentemente, uma planta ruderal, embora tenha sido coletada também em locais preservados. Floresce e frutifica em todos os meses do ano.

Pode ser confundida com Polygala pulchella e P. linoides, diferindo destas por apresentar glândulas nas estruturas florais, caule e folhas, e pelas sépalas externas inseridas em dois pontos diferentes.

3.23. Polygala pulchella A. St.-Hil. \& Moq., Mém. Mus. Hist. Nat. 17: 368. 1828

Figura $10 \mathrm{~h}-\mathrm{k}$

Ervas eretas a subdecumbentes, 5,5-30 cm alt. Caule folioso, cilíndrico, levemente estriado ou anguloso, densamente piloso, com tricomas curtos, sem glândulas, com ramificação basal, mediana ou terminal. Folhas sésseis, alternas, papiráceas, glabras ou pilosas, sem glândulas, lineares, estreito-elípticas, obovadas, estreito-oblongas ou oblongas, lâminas $2-11 \times 0,5-1,1 \mathrm{~mm}$, ápice mucronado, agudo, acuminado ou cuspidado, base aguda, obtusa ou atenuada, margem inteira ou serreada, ciliada. Brácteas e bractéolas decíduas, margem lisa. Racemos pedunculados, terminais, cilíndricos, 0,7-9,5 cm compr., laxifloros ou subdensifloros. Flores 1,5-2,6 mm compr., brancas, branco-esverdeadas ou brancas com manchas rosadas; pedicelos 0,3-1 mm compr., glabros, eretos ou reflexos na frutificação. Sépalas externas glabras, sem glândulas, ápice obtuso ou agudo, margem inteira; uma sépala elíptica, ovada ou largo-ovada, 0,9-1,5 mm compr.; duas sépalas livres e iguais entre si, elípticas ou ovadas, 
0,7-1,3 mm compr.; sépalas internas glabras, sem glândulas, elípticas, espatuladas ou largo-espatuladas, 1,5-2,6 mm compr., ápice arredondado, base atenuada. Pétalas laterais glabras, sem glândulas, elípticas, 1,2-2 mm compr., ápice obtuso; carena cristada, sem glândulas, crista 0,5-1 mm compr., com 4-6 lobos simples. Ovário glabro, sem glândulas, cordiforme. Cápsulas glabras, sem glândulas, elípticas ou oblongas, 1-1,8 mm compr., não estipitadas, não aladas. Sementes pubérulas, elipsoides, 1-1,7 mm compr., com apêndice membranáceo profundamente bilobado, atingindo a metade ou ultrapassando $0,2 \mathrm{~mm}$ do comprimento da semente.

Material selecionado: BRASIL. PARANÁ: Campo do Tenente, BR 427, km 27, próximo ao Rio da Várzea,

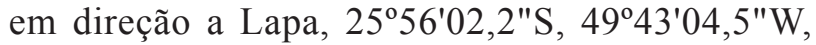
22-II-2006, R. Lüdtke 523 (ICN); Carambeí, PR 151,

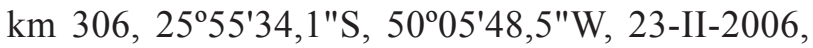
R. Lüdtke 537 (ICN); Castro, PR 151, km 302, em direção a Ponta Grossa, 245' $43^{\prime} 40,0^{\prime \prime} \mathrm{S}, 50^{\circ} 04^{\prime} 04,2^{\prime \prime} \mathrm{W}$, 23-II-2006, R. Lüdtke 541 (ICN); Guarapuava, PR 460, 2514'59,9" S, 5132'19,1" W, 20-XII-2006, R. Lüdtke 688 (ICN); Palmas, PR 280, 26²9'07,0"S, $52^{\circ} 02^{\prime} 46,8^{\prime \prime} \mathrm{W}, 18-\mathrm{XII}-2006$, R. Lüdtke 680 (ICN). Rio Grande do Sul: Almirante Tamandaré do Sul, BR 386, km 160, 28 $8^{\circ} 10^{\prime} 34,3^{\prime \prime} \mathrm{S}, 52^{\circ} 50^{\prime} 10,9^{\prime \prime} \mathrm{W}$, 9-X-2006, R. Lüdtke 580 (ICN); Bagé, BR 153, km 632, 23-XI-2002, R. Lüdtke 83 (ICN); Campestre da Serra, BR 116, km 63, 3-XI-2003, R. Lüdtke 195 (ICN); Candelária, IX-1985, M. Sobral et al. 4361 (ICN); Pedras Altas, RS 608, para Pinheiro Machado, 31 46'12,5"S, 53³6'48,2"W, 31-X-2006, R. Lüdtke 643 (ICN); Planalto, Reserva Florestal de Planalto, 7-XII-1974, L.R.M. Baptista et al. s.n. (ICN26830); Porto Alegre, Morro São Pedro, 30 11 '23,7"S, $51^{\circ} 07^{\prime} 08,2^{\prime \prime W}, 14-X I-2005$, S.T.S. Miotto 2240 (ICN); Santiago, BR 287, a 7 km da cidade, sentido São Borja, 20-XI-2002, R. Lüdtke 55 (ICN). SANTA CATARINA: Bom Retiro, BR 282, km 138, 2749'39,3"S, 49³4'09,0"W, 29-XI-2006, R. Lüdtke 670 (ICN); Calmon, BR 302, $\mathrm{km}$ 55, estrada de Caçador a Calmon, 2636'14,3"S,

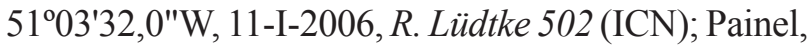
$\mathrm{km} 35$ da rodovia Lages - São Joaquim, 20-X-2004, R. Lüdtke 263 (ICN); Ponte Alta, BR 116, km 194, $27^{\circ} 22^{\prime} 18,7^{\prime \prime S}, 50^{\circ} 25^{\prime} 46,2^{\prime \prime} \mathrm{W}, 11-\mathrm{X}-2006$, R. Lüdtke 594 (ICN); Porto União, 25-II-1962, R. Reitz \& R. Klein 12415 (HBR); Xaxim, BR 282, km 513, 26 $6^{\circ} 55^{\prime} 31,7^{\prime \prime S}, 52^{\circ} 29^{\prime} 50,4^{\prime \prime} \mathrm{W}, 10-\mathrm{X}-2006$, R. Lüdtke 584 (ICN).
Polygala pulchella ocorre na Argentina, Uruguai e Brasil: Minas Gerais, Espírito Santo, Rio de Janeiro, São Paulo, Paraná, Santa Catarina e Rio Grande do Sul (Grondona 1948, Angely 1965, Marques 1979, Marques 1988, Bernardi 2000, Marques \& Gomes 2002, Lüdtke \& Miotto 2004). Espécie de ampla distribuição, sendo encontrada em campos pastejados, graminosos, arbustivos, pedregosos, graníticos, areníticos, lateríticos, em baixadas úmidas, em capoeiras, banhados, beira de matas nebulares e, menos comumente, associada a espécies de Sphagnum. Floresce e frutifica em todos os meses do ano.

Pode ser confundida com Polygala australis pelo hábito, porém, difere desta pelas sementes que são desprovidas da coroa de tricomas rígidos. Além disso, podendo ser facilmente confundida com $P$. linoides, tendo sido discutidas as diferenças entre as espécies nas observações sobre $P$. linoides.

3.24. Polygala pumila Norl., Repert. Spec. Nov. Regnii Veg. 13: 401. 1914.

Figura 11a-d

Ervas subdecumbentes ou decumbentes, 3,5-5 cm alt. Caule folioso, cilíndrico, subanguloso ou anguloso, escassamente piloso, com tricomas curtos, sem glândulas, com ramificação basal. Folhas pecioladas, opostas na base e alternas no ápice da planta, cartáceas, pilosas, com ou sem glândulas, ovadas a elípticas, lâminas 2,5-8,9 × 1,3-5 mm, ápice agudo, apiculado, base obtusa ou atenuada, margem inteira ou levemente serreada, lisa; pecíolos 0,5-0,8 mm compr. Brácteas e bractéolas persistentes, margem ciliada. Racemos subsésseis, terminais, subcapitados, cilíndricos ou curto-cilíndricos, 0,8-2,5 cm compr., densifloros. Flores 3-3,5 mm compr., brancas ou creme; pedicelos $0,5-1 \mathrm{~mm}$ compr., glabros, eretos ou patentes na frutificação. Sépalas externas glabras, glandulosas, ápice agudo, margem ciliada; uma sépala lanceolada, 2-2,2 mm compr.; duas sépalas livres e iguais entre si, estreito-lanceoladas, 1,3-2 mm compr.; sépalas internas glabras, glandulosas, elípticas ou oblongo-elípticas, 3-3,8 mm compr., ápice arredondado ou emarginado, base atenuada. Pétalas laterais glabras, sem glândulas, elíptico-assimétricas, 2,2-3 mm compr., ápice obtuso; carena cristada, com ou sem glândulas no dorso, crista 1-1,1 mm compr., com 6 lobos simples, bífidos ou trífidos. Ovário piloso, glanduloso, elíptico. Cápsulas glabras, glandulosas, oblongas, 2,2-2,5 mm compr., não estipitadas, aladas, emarginadas nos dois bordos. Sementes pubescentes, 


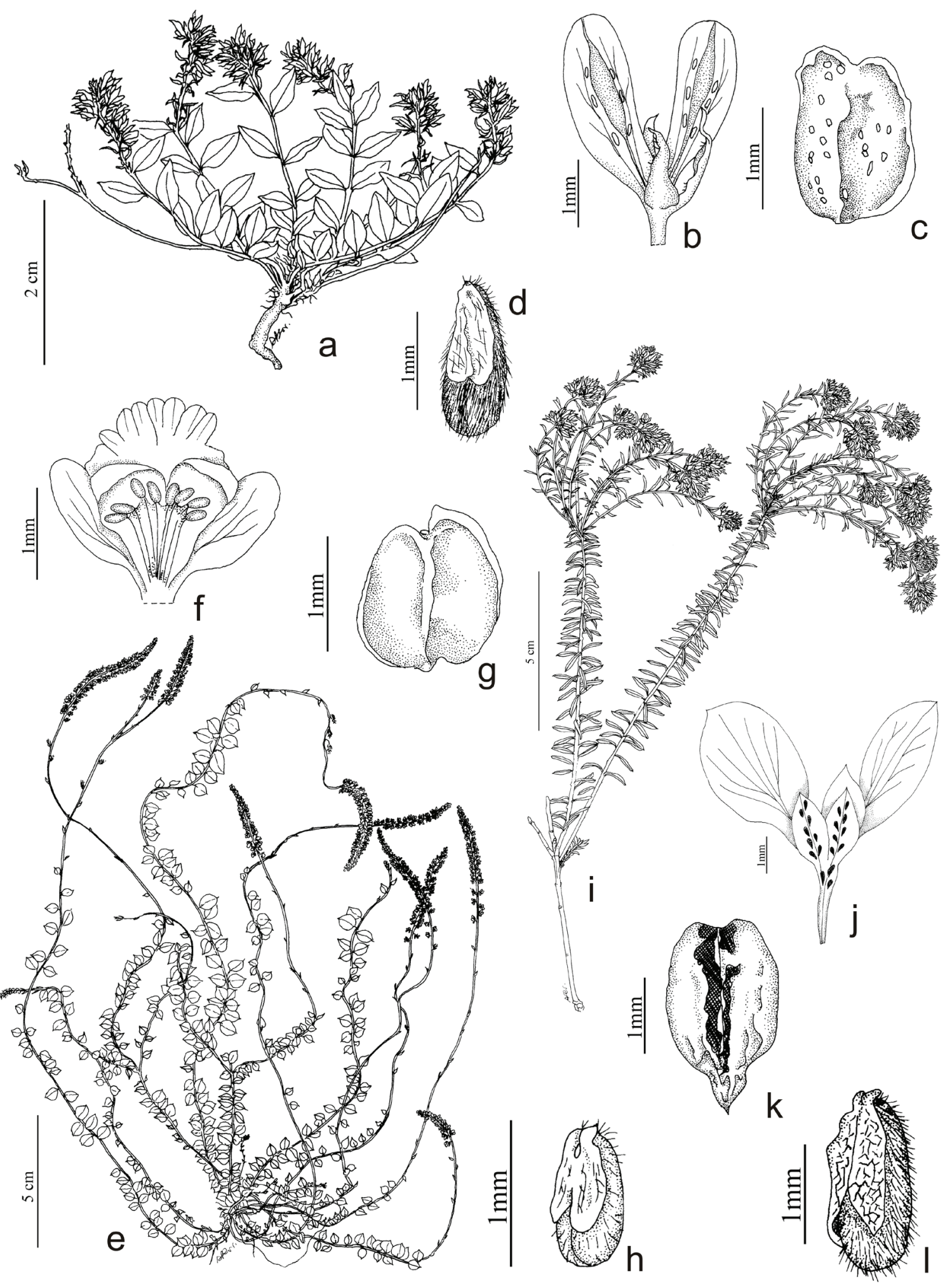

Figura 11. a-d. Polygala pumila. a. Hábito. b. Cálice. c. Fruto. d. Semente. e-h. Polygala riograndensis. e. Hábito. f. Corola e androceu em secção longitudinal. g. Fruto. h. Semente. i-1. Polygala sabulosa. i. Hábito. j. Cálice. k. Fruto. 1. Semente. [a-c: Miotto s.n. (ICN130856); d: Mattos \& Mattos 26238 (HAS); e-h: Lüdtke 190 (ICN); i: Falkenberg \& Silva Filho 5985 (ICN); j-1: Lüdtke 91 (ICN)].

Figure 11. a-d. Polygala pumila. a. Habit. b. Calyx. c. Fruit. d. Seed. e-h. Polygala riograndensis. e. Habit. f. Corolla and androecium in longitudinal section. g. Fruit. h. Seed. i-1. Polygala sabulosa. i. Habit. j. Calyx. k. Fruit. 1. Seed. [a-c: Miotto s.n. (ICN130856); d: Mattos \& Mattos 26238 (HAS); e-h: Lüdtke 190 (ICN); i: Falkenberg \& Silva Filho 5985 (ICN); j-1: Lüdtke 91 (ICN)]. 
com tricomas seríceos, ovoides, 1,5-1,7 mm compr., com apêndice membranáceo profundamente bilobado, atingindo de $3 / 4$ ao comprimento total da semente.

Material selecionado: BRASIL. PARANÁ: Arapoti, entre Arapoti e Wenceslau Braz, 22-III-1968, G. Hatschbach 18905 (MBM); Balsa Nova, Serra São Luis, 6-I-1971, G. Hatschbach 25949 (MBM, NY); Lapa, Serrinha, 22-XI-1909, P. Dusén 8941 (S); Ponta Grossa, BR 277, km 142, 25'26'45,9"S, 4944'29,0"W, 8-XI-2007, R. Lüdtke 809 (ICN); São Jerônimo da Serra, 28-X-1999, A.M. Mendonça et al. 39 (FUEL). Rio Grande do Sul: Arroio dos Ratos, I-1942, J.E. Leite 488 (SP); Cambará do Sul, Itaimbezinho, 4-I-1978, S.T.S. Miotto 766 (ICN); Eldorado do Sul (Guaíba), Estação Experimental Agronômica da UFRGS, 28-X-1970, A. Pott 126 (BLA); Giruá, Granja Sodol, 7-IV-1965, K. Hagelund 3533 (ICN); Panambi, 18-X-1904, A. Bornmüller 240 (GH); Passo Fundo, entre Passo Fundo e Carazinho, 2-X-1971, J.C. Lindeman et al. s.n. (ICN8197). SAnta Catarina: Campo Alegre, Morro do Iquererim, 18-X-1957, R. Reitz \& R. Klein 5256 (HBR).

Polygala pumila ocorre no Brasil: Minas Gerais, São Paulo, Paraná, Santa Catarina e Rio Grande do Sul (Angely 1965, Bernardi 2000, Marques \& Gomes 2002, Lüdtke \& Miotto 2004). Encontrada em campos arbustivos, secos, ou em campos graminosos próximos a turfeiras com solos úmidos. Floresce e frutifica de setembro a abril.

Erva diminuta, com até $5 \mathrm{~cm}$ de altura, muito ramosa na base, com pequeno xilopódio, frequentemente encontrada nos campos de altitude. Apresenta folhas geralmente opostas, brácteas e bractéolas persistentes, flores brancas ou creme e glândulas nas peças florais.

\subsection{Polygala riograndensis Lüdtke \& Miotto,} Novon 17: 40. 2007.

Figura 11e-h

Ervas decumbentes ou prostradas, $11-34 \mathrm{~cm}$ alt. Caule folioso, cilíndrico na base e quadrangular no ápice ou subanguloso, glabro, escassa ou densamente piloso, com tricomas curtos, sem glândulas, com ramificação basal, mediana ou terminal. Folhas pecioladas, alternas, membranáceas, glabras, sem glândulas, ovadas, largo-ovadas ou largo-elípticas, lâminas 3-10 × 2,5-7 mm, ápice apiculado, acuminado ou cuspidado, base aguda, arredondada ou obtusa, margem inteira, lisa; pecíolos 0,4-0,6 mm compr. Brácteas e bractéolas decíduas, margem lisa ou ciliada. Racemos pedunculados, terminais ou axilares, estreito-cilíndricos, $2-12 \mathrm{~cm}$ compr., densifloros. Flores 2-2,5 mm compr., brancas ou branco-esverdeadas; pedicelos 0,5-1,2 mm compr., glabros, reflexos na frutificação. Sépalas externas glabras, sem glândulas, ápice agudo, margem inteira; uma sépala ovado-elíptica, 1,1-1,5 mm compr.; duas sépalas livres e iguais entre si, elípticas, 1-1,2 mm compr.; sépalas internas glabras, sem glândulas, elípticas, 2-2,5 mm compr., ápice arredondado, base atenuada. Pétalas laterais glabras, sem glândulas, elípticas, 1,5-2 mm compr., ápice arredondado; carena cristada, sem glândulas, crista $0,8-1 \mathrm{~mm}$ compr., com 6-7 lobos simples ou bífidos. Ovário glabro, sem glândulas, largo-elíptico. Cápsulas glabras, sem glândulas, ovado-orbiculares ou largooblongas, 1,3-1,8 mm compr., não estipitadas, aladas, emarginadas nos dois bordos. Sementes escassamente pubescentes, oblongas, 1-1,3 $\mathrm{mm}$ de compr., com apêndice membranáceo profundamente bilobado, atingindo desde $3 / 4$ até o comprimento total da semente.

Material selecionado: BRASIL. Rio Grande Do Sul: Aceguá, BR 153, km 473, 31ํ34'46,3"S,

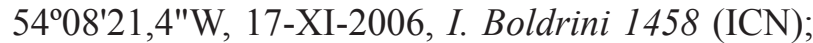
Arroio dos Ratos, Fazenda Faxinal, 26-X-1983, O. Bueno 3694 (HAS); Arroio Grande, BR 116, 585, $32^{\circ} 03^{\prime} 40,3^{\prime \prime S}, 52^{\circ} 52^{\prime} 21,4^{\prime \prime} \mathrm{W}, 31-\mathrm{X}-2006$, R. Lüdtke 624 (ICN); Encruzilhada do Sul, Estação Experimental, 25-XI-1972, A. Pott s.n. (BLA8018, ICN20917); Guaíba, Fazenda São Maximiano, BR 116, km 307, 17-IX-2006, E. Freitas s.n. (ICN144938); Itaara (Santa Maria), Reserva Biológica do Ibicuí-Mirim, Campo dos Barcelos, 3-X-1989, M.L. Abruzzi 1840 (HAS); Jaguarão, BR 116, km 652, 32³1'28,2"S, $52^{\circ} 20^{\prime} 49,4^{\prime \prime} \mathrm{W}, 31-\mathrm{X}-2006$, R. Lüdtke 627 (ICN); Lavras do Sul, Mina Volta Grande, IX-1984, M. Sobral 3121 (ICN); Pinheiro Machado, BR 293, km 80, 31'39'19,8"S, 5307'26,4"W, 1-X-2006, R. Lüdtke 647 (ICN); Porto Alegre, Morro da Polícia, 10-X-2003, R. Lüdtke 190 (ICN).

Polygala riograndensis ocorre no Brasil, apenas no Rio Grande do Sul (Lüdtke \& Miotto 2007). Frequente em campos rupestres, rochosos, morros graníticos, associada a espécies do gênero Eryngium, em morros de arenito e em campos alterados. Floresce e frutifica de setembro a fevereiro.

Polygala riograndensis é afim de $P$. campestris, diferindo desta por apresentar caules sinuosos, cápsula alada, folhas pecioladas e glabras e crista da carena com 6-7 lobos. 
3.26. Polygala sabulosa A.W. Benn., Fl. Bras. 13(3): 27. 1874.

$=$ P. hatschbachii Brade, Arq. Jard. Bot. do Rio de Janeiro, 13: 22. 1954.

Figura 11i-1

Subarbustos eretos ou decumbentes, 9-46 cm alt. Caule folioso, quadrangular, estriado ou cilíndrico na base e quadrangular no ápice, escassamente piloso, com tricomas curtos, sem glândulas, com ramificação basal, terminal ou mediana, umbeliforme. Folhas sésseis, alternas ou opostas na base e alternas no ápice da planta, subcarnosas ou carnosas, glabras, glandulosas, elípticas, lâminas 4-10 × 0,7-2 mm, ápice mucronado, base atenuada, margem revoluta, lisa. Brácteas e bractéolas tardiamente decíduas, margem lisa. Racemos pedunculados, terminais, subcapitados ou capitados, 0,6-2,5 cm compr., densifloros. Flores 3-5,1 mm compr., rosadas ou lilases; pedicelos 1,3-2 mm compr., glabros, patentes ou reflexos na frutificação. Sépalas externas glabras, glandulosas, ápice agudo, margem denteada; uma sépala elíptica, 1-2 mm compr.; duas sépalas livres e iguais entre si, ovadas, 1-1,8 mm compr.; sépalas internas glabras, glandulosas, elípticas, 3-5 mm compr., ápice obtuso ou agudo, base atenuada. Pétalas laterais glabras, com ou sem glândulas, elípticas, 2,5-3,7 mm compr., ápice obtuso; carena cristada, glandulosa no dorso, crista 1-1,2 mm compr., com 6-8 lobos simples ou bífidos. Ovário glabro, glanduloso, elíptico ou suborbicular. Cápsulas glabras, glandulosas, oblongo-orbiculares, 2,2-3 mm compr., estipitadas, não aladas. Sementes pubérulas ou pubescentes, elipsoides, 1,2-2,2 mm compr., com apêndice membranáceo profundamente bilobado, atingindo desde $1 / 5$ até ultrapassando em $0,2 \mathrm{~mm}$ do comprimento da semente.

Material selecionado: BRASIL. Paraná: Campo Largo, 11-XI-1966, J.C. Lindeman \& J.H. Haas 2966 (U); Guarapuava, Serra da Esperança, 20-X-1960, G. Hatschbach 7340 (HBR, MBM); Inácio Martins, Rio Bananas, 20-IX-2001, G. Hatschbach et al. 72448 (MBM); Jaguariaíva, estrada para o Parque Estadual do Cerrado, $24^{\circ} 12^{\prime} 38,2^{\prime \prime} \mathrm{S}, 49^{\circ} 41^{\prime} 04,3^{\prime \prime} \mathrm{W}, 10-\mathrm{I}-2007$, R. Lültke 721 (ICN); Marmeleiro, na estrada para Campo Erê, 25-X-1969, G. Hatschbach 22650 (MBM); Sengés, margens do Rio Funil, 4-XII-1988, M.C. Dias et al. s.n. (FUEL5998); Tibagí, Fazenda Monte Alegre, 25-X-1953, G. Hatschbach 3958 (MBM); União da Vitória, São Cristovão, 18-XI-1972, G. Hatschbach 30683 (MBM); Ventania, Fazenda Santa Inês, 22-VI-2005, D.A. Estevan et al. 740 (FUEL, ICN). Rio Grande do Sul: Arroio dos Ratos,
Fazenda Faxinal, 22-IX-1978, K. Hagelund 12453 (ICN); Cambará do Sul, Itaimbezinho, trilha do Cotovelo, 9-X-2004, R. Lüdtke 236 (ICN); Caxias do Sul, Vila Oliva, 1-I-1946, B. Rambo 33869 (NY, PACA); Nova Petrópolis, 11-III-1963, A. Sehnem s.n. (HUCS8182); São José dos Ausentes, RST 285, a 2 km do Vale das Trutas em direção a Serra da Rocinha, 21-X-2004, R. Lüdtke 272 (ICN); Vacaria, Fazenda da Ronda, 30-XII-1946, B. Rambo 34695 (PACA). Santa Catarina: Alfredo Wagner, BR 282, Morro do Trombudo, 7-XII-2000, G. Hatschbach et al. 71581 (MBM); Bom Jardim da Serra, SC 438, divisa do município com Lauro Müller, a $11 \mathrm{~km}$ da cidade, 28²4'04,0"S, 49³3'04,6"W, 19-X-2004, R. Lüdtke 243 (ICN); Mafra, BR 280, km 171, em direção a Canoinhas, $26^{\circ} 10.361^{\prime} \mathrm{S}, 49^{\circ} 54.287^{\prime} \mathrm{W}, 20-\mathrm{X}-2005$, R. Lüdtke 417 (ICN); Rancho Queimado BR 282, $\mathrm{km} 58$, em frente a Polícia Rodoviária Federal, 27ํ1'16,6"S, 4902'06.6W, 29-XI-2006, R. Lüdtke 676 (ICN).

Polygala sabulosa ocorre no Brasil: Minas Gerais, São Paulo, Paraná, Santa Catarina e Rio Grande do Sul (Wurdack \& Smith 1971, Marques 1988, Bernardi 2000, Marques \& Gomes 2002, Lüdtke \& Miotto 2004). É frequentemente encontrada em locais úmidos, beiras de banhados, turfeiras, brejos, em depressões úmidas ou, ainda, em campos graminosos, secos, rochosos que beiram as escarpas dos Aparados da Serra e as estradas de acesso. Floresce e frutifica em todos os meses do ano.

Distingue-se das demais espécies pela ramificação mediana umbeliforme, além de apresentar as folhas com consistência carnosa. Pelo aspecto geral assemelha-se à Polygala cyparissias e $P$. aspalatha, porém, estas apresentam cápsulas aladas, sementes globosas, além de não possuírem glândulas em suas estruturas.

3.27. Polygala selaginoides A.W. Benn., Fl. Bras. 13(3): 38. 1874.

Figura 12a-c

Subarbustos eretos, $66-78 \mathrm{~cm}$ alt. Caule folioso, cilíndrico, densamente piloso, com tricomas curtos, sem glândulas, com ramificação basal, mediana ou terminal. Folhas sésseis, alternas, cartáceas ou subcarnosas, glabras, sem glândulas, lanceoladas, imbricadas, lâminas 3,5-8,5 × 0,8-1 mm, ápice agudo, base cuneada, margem denticulada, lisa. Brácteas e bractéolas decíduas, margem ciliada. Racemos pedunculados, terminais, estreito-cilíndricos, espiciformes, 2,5-12 cm compr., densifloros. Flores 


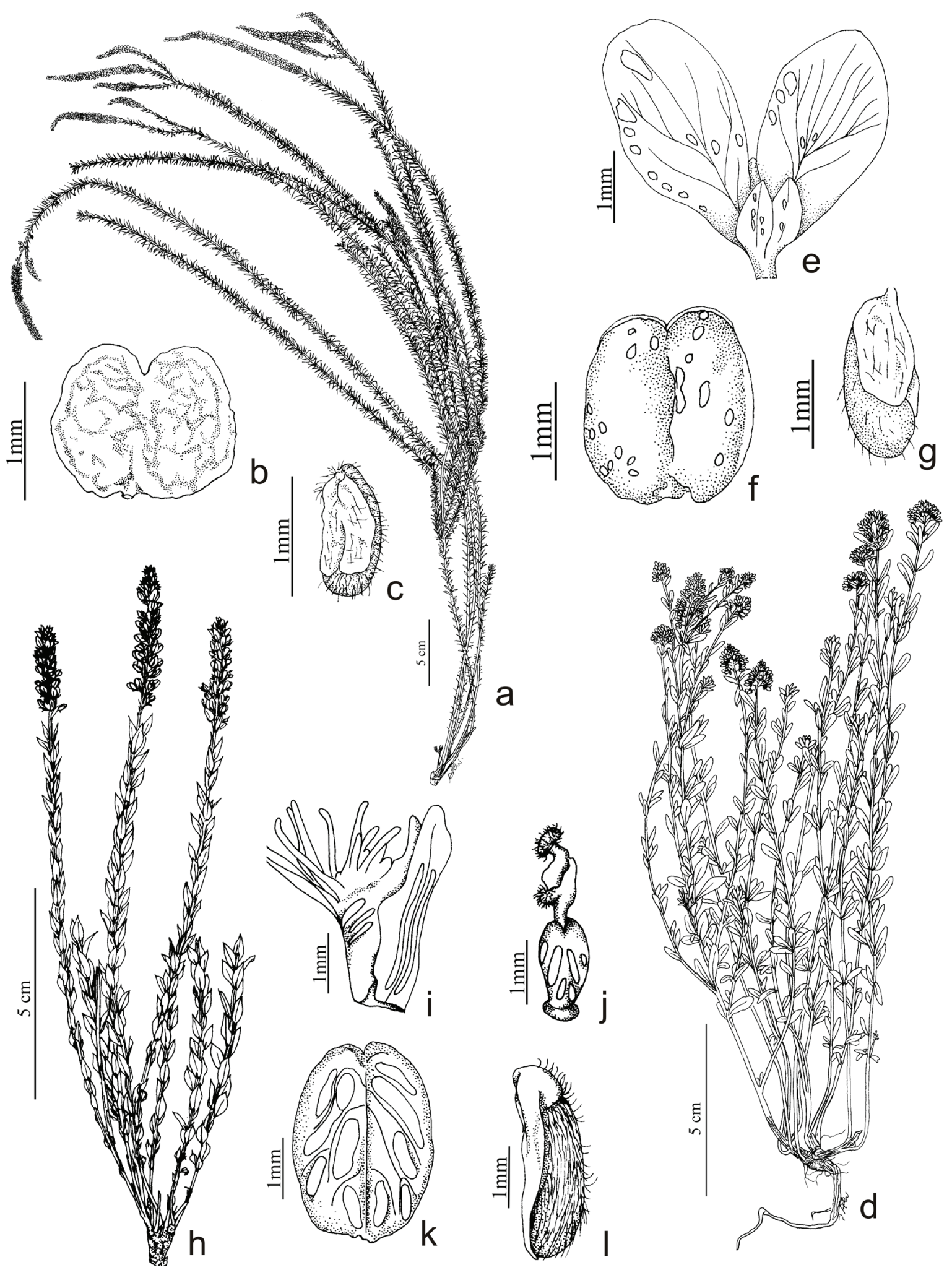

Figura 12. a-c. Polygala selaginoides. a. Hábito. b. Fruto. c. Semente. d-g. Polygala subverticillata. d. Hábito. e. Cálice. f. Fruto. g. Semente. h-1. Polygala telephium. h. Hábito. i. Corola em vista lateral. j. Gineceu. k. Fruto. 1. Semente. [a-c: Jarenkow et al. 135 (ICN); d: Rambo 36169 (PACA); e-g: Rambo 53780 (PACA); h, k, 1: Hatschbach \& Occhioni 15097 (MBM); i, j: Dusén 1911 (S)].

Figure 12. a-c. Polygala selaginoides. a. Habit. b. Fruit. c. Seed. d-g. Polygala subverticillata. d. Habit. e. Calyx. f. Fruit. g. Seed. h-1. Polygala telephium. h. Habit. i. Corolla in lateral view. j. Gynoecium. k. Fruit. 1. Seed. [a-c: Jarenkow et al. 135 (ICN); d: Rambo 36169 (PACA); e-g: Rambo 53780 (PACA); h, k, l: Hatschbach \& Occhioni 15097 (MBM); i, j: Dusén 1911 (S)]. 
2,5-2,8 mm compr., brancas; pedicelos $0,2 \mathrm{~mm}$ compr., glabros, eretos ou patentes na frutificação. Sépalas externas glabras, sem glândulas, ápice obtuso ou agudo, margem inteira; uma sépala largo-ovada, 1,3-1,5 mm compr.; duas sépalas livres e iguais entre si, ovadas, 1,1-1,4 mm compr.; sépalas internas glabras, sem glândulas, suborbiculares, 2,5-2,8 mm compr., ápice agudo ou arredondado, base unguiculada. Pétalas laterais glabras, sem glândulas, elípticas, 1,5-2,5 mm compr., ápice obtuso ou agudo; carena cristada, sem glândulas, crista $0,8-1 \mathrm{~mm}$ compr., com 4-6 lobos simples ou bífidos. Ovário glabro, sem glândulas, suborbicular. Cápsulas glabras, sem glândulas, suborbiculares, 1,8 mm compr., não estipitadas, aladas, emarginadas em ambos os bordos. Sementes pubescentes, reniformes, elipsoides, 1,4 mm compr., com apêndice membranáceo profundamente bilobado, atingindo $1 / 4$ do comprimento da semente.

Material examinado: BRASIL. PARANÁ: Piên, próximo ao trevo, 18-X-2006, J. Cordeiro et al. 2384 (MBM). Rio Grande do Sul: Campestre da Serra (Vacaria), BR 116, km 62, 9-XI-1984, J.A. Jarenkow et al. 135 (ICN, MBM); idem, BR 116, km 62, 28³9'34,4"S, $51^{\circ} 03^{\prime} 32,1^{\prime \prime} \mathrm{W}, 5-\mathrm{XI}-2007$, R. Lüdtke \& A.A. Schneider 774 (ICN); Itaara (Santa Maria), Reserva Biológica do Ibicuí-Mirim, Barragem Saturnino de Brito, 7-VII-1982, M.L. Abruzzi 680 (HAS).

Polygala selaginoides ocorre no Uruguai e Brasil: Paraná e Rio Grande do Sul (Bernardi 2000, Lüdtke $\&$ Miotto 2004). Pela primeira vez esta espécie está sendo referida para o Paraná. Bernardi (2000) citou $P$. selaginoides para Santa Catarina, porém, Wurdack \& Smith (1971) não confirmaram esta espécie para o referido Estado, e o exemplar citado por Bernardi (2000) não foi analisado durante a realização deste trabalho. Possivelmente esta espécie ocorra em Santa Catarina, uma vez que é encontrada nos outros Estados sulinos, mas nenhum exemplar foi coletado e nenhuma coleta proveniente deste Estado foi revisada. A espécie é encontrada em campos úmidos e beiras de estradas com afloramentos rochosos. Coletada com flores e frutos nos meses de julho, outubro e novembro.

As folhas numerosas, imbricadas e as inflorescências espiciformes são características marcantes para distinguir esta espécie das demais.

\subsection{Polygala subverticillata Chodat, Bot. Jahrb. 5.} Beibl. 115: 80. 1914.

Figura 12d-g

Subarbustos eretos ou decumbentes, $13-52 \mathrm{~cm}$ alt. Caule folioso, cilíndrico, fortemente estriado ou anguloso, glabro, sem glândulas, com ramificação basal, mediana ou terminal. Folhas sésseis, alternas na base e subverticiladas no ápice da planta, cartáceas ou subcarnosas, glabras, glandulosas, obovadas, elípticas, oblongas ou estreito-oblongas, lâminas 3-12 × 1-5 mm, ápice mucronado, obtuso, agudo ou arredondado, base obtusa ou cuneada, margem revoluta, lisa. Brácteas e bractéolas decíduas, margem lisa. Racemos sésseis, terminais, capitados, subcapitados ou curtocilíndricos, 0,5-2 cm compr., densifloros. Flores 3,5-5 mm compr., rosadas a violáceas; pedicelos 1-2,1 mm compr., glabros, eretos, patentes ou reflexos na frutificação. Sépalas externas glabras, glandulosas, ápice obtuso, margem inteira; uma sépala largo-ovada, 1,7-2 mm compr.; duas sépalas livres e iguais entre si, ovadas, 1,3-2,7 mm compr.; sépalas internas glabras, glandulosas, largo-obovadas ou orbiculares, 4-5,2 mm compr., ápice obtuso ou arredondado, base atenuada. Pétalas laterais glabras, glandulosas, elípticas, largo-elípticas ou obovadas, 3-3,7 mm compr., ápice obtuso; carena cristada, glandulosas no dorso, crista 1-1,5 mm compr., com 8-10 lobos simples ou bífidos. Ovário glabro, glanduloso, suborbicular. Cápsulas glabras, glandulosas, oblongas ou suborbiculares, 2,2-3 mm compr., não estipitadas, aladas, emarginadas em ambos os bordos. Sementes escassamente pubescentes, obovoides, 2-2,5 mm compr., com apêndice membranáceo profundamente bilobado, atingindo de 1/2 a 3/4 do comprimento da semente.

Material selecionado: BRASIL. PARANÁ: Campina Grande do Sul, Morro Tocum, 22-V-1971, N. Imaguire 451(MBM). Rio Grande do Sul: Bom Jesus, Faxinal Preto, 21-IX-1850, R. Reitz 3405 (S); Cambará do Sul, Itaimbezinho, 21-II-1951, B. Rambo 50068 (PACA, S); Canela, entrada para o Hotel Laje de Pedra, 23-XI-1993, O. Bueno 6313 (HAS); Guaíba, Fazenda São Maximiano, 22-IX-1987, S.A.L. Bordignon 686 (ICN); São José dos Ausentes (Bom Jesus), Serra da Rocinha, 14-I-1942, B. Rambo 3639 (PACA). SANTA CATARINA: Bom Jardim da Serra, perto de São Joaquim, 29-I-1950, R. Reitz 5089 (PACA); Campo Alegre, Morro do Iquererim, 8-XI-1956, L.B. Smith \& R. Klein 7396 (B, NY, RB); Garuva, Morro do Campo Alegre, 7-X-1960, R. Reitz \& R. Klein 10071 (B, HBR, NY, PACA, RB); Jacinto Machado (Araranguá), Serra da Pedra, 28-XII-1943, R. Reitz 746 (HBR, RB); Rodeio Grande, Serra do Quiriri, Rio dos Alemães, 14-I-1998, O.S. Ribas et al. 2256 (MBM). 
Polygala subverticillata ocorre no Brasil: Paraná, Santa Catarina e Rio Grande do Sul (Wurdack \& Smith 1971, Marques 1988, Bernardi 2000, Lüdtke \& Miotto 2004). Pode ser encontrada em solos turfosos, úmidos, em matas de pinhais de encosta e em campos arbustivos de encosta. Floresce e frutifica em todos os meses do ano.

Bernardi (2000) sinonimizou Polygala subverticillata com P. cneorum A. St.-Hil. \& Moq. a qual nunca havia sido citada para a região Sul do Brasil por Marques (1988) e Marques \& Gomes (2002). Além disso, P. cneorum apresenta caule com tricomas glandulares clavados, folhas pecioladas raramente subverticiladas na base, racemo curtamente pedunculado e corola persistente no fruto. Já em P. subverticillata o caule é glabro, as folhas são sésseis e predominantemente subverticiladas, os racemos são sempre sésseis e a corola é caduca, jamais persistindo no fruto. Portanto, rejeita-se a sinonimização proposta por Bernardi (2000) e considera-se $P$. subverticillata uma espécie distinta.

3.29. Polygala telephium Chodat, Bull. Herb. Boissier 2, 1: 435. 1901.

Figura 12h-1

Subarbustos eretos, $10-19 \mathrm{~cm}$ alt. Caule densamente folioso, quadrangular, anguloso, glabro, sem glândulas, com intensa ramificação basal. Folhas numerosas, sésseis, alternas, raro opostas, adpressas ao caule, cartáceas, glabras, sem glândulas, ovadas ou elíptico-lanceoladas, lâminas 5-13 × 1-3,5 mm, ápice caudado ou cuspidado, base cuneada, margem inteira ou irregular, lisa. Brácteas e bractéolas tardiamente decíduas a persistentes, margem ciliada. Racemos pedunculados, terminais, cilíndricos a piramidais, 2-6 cm compr., densifloros. Flores 3-4 mm compr., creme, creme-esverdeadas, brancas, pedicelos 0,8-1,5 mm compr., glabros, eretos na frutificação. Sépalas externas glabras, glandulosas, ápice agudo ou obtuso, margem ciliada; uma sépala largo-ovada ou lanceolada, 1,5-2,2 mm compr.; duas sépalas livres e iguais entre si, ovadas ou lanceoladas, 1,3-2 mm compr.; sépalas internas glabras, glandulosas, elípticas a largo-elípticas, 3-3,7 mm compr., ápice obtuso ou arredondado, base atenuada. Pétalas laterais glabras, glandulosas ou não, rômbicas, 2,3-3,8 mm compr., com ápice obtuso; carena cristada, glandulosa no dorso, crista com 1-1,8 mm compr., com 6-9 lobos simples e bífidos. Ovário glabro, glanduloso, oblongo, com disco na base. Cápsulas glabras, glandulosas, oblongas, 3-3,5 mm compr., não estipitadas, não aladas. Sementes densamente pubescentes, estreito-ovoides, 2,8-3,2 mm compr., com apêndice membranáceo totalmente bilobado, atingindo o comprimento da semente.

Material examinado: BRASIL. PARANÁ: Jaguariaíva, 17-X-1966, J.C. Lindeman \& J.H. Haas 3107 (MBM); Monte Alegre, 22-XI-1954, Kuhlmann s.n. (RB150770); Ponta Grossa, Desvio Ribas, 20-X-1914, P. Dusén 15744 (GH); idem, Parque Estadual Vila Velha, 9-XI-1966, G. Hatschbach \& P. Occhioni 15097 (MBM, NY, RB); Sengés, Rio dos Bugres, 12-XI-1974, G. Hatschbach 35415 (MBM, RB); idem, Serra do Mocambo, 19-IX-1975, G. Hatschbach 37110 (MBM, RB). Rio Grande do Sul: Guaíba, Fazenda São Maximiano, BR 116, km 308, 8-XI-1998, N.I. Matzembacher 2301 (ICN); idem, 24-X-2003, V.F. Kinupp et al. 2798 (ICN).

Polygala telephium ocorre no Brasil: Minas Gerais, São Paulo, Paraná e Rio Grande do Sul (Marques 1988). Até o momento não existe uma coleta realizada no Estado de Santa Catarina e pela primeira vez esta espécie está sendo referida para o Rio Grande do Sul. É encontrada em campos graminosos, pedregosos, de solos secos ou úmidos. Floresce e frutifica de setembro a dezembro.

Bernardi (2000) referiu Polygala telephium como sinônimo de uma variedade de $P$. adenophylla, porém ambas as espécies são distintas morfologicamente. Enquanto $P$. adenophylla apresenta hábito herbáceo, filotaxia verticilada, folhas glandulosas e nunca adpressas ao caule, $P$. telephium apresenta hábito subarbustivo, folhas alternas, raro opostas, adpressas ao caule e desprovidas de glândulas. Portanto, no presente trabalho rejeita-se o tratamento dado para Polygala telephium por Bernardi (2000) e opta-se pela recuperação deste nome.

Marques (1979) citou Polygala angulata DC. var. diffusa A.W. Benn. para o Estado do Paraná, mas após a análise do material examinado, citado por Marques (1979), percebeu-se que se tratava, na realidade, de P. telephium.

3.30. Polygala tenuis DC., Prod. 1: 329. 1824.

Figura 13a-d

Ervas ou subarbustos eretos, $12-47 \mathrm{~cm}$ alt. Caule subáfilo ou pouco folioso, cilíndrico, glabro, sem glândulas, com ramificação mediana ou terminal. Folhas escassas, sésseis, alternas, membranáceas a 
subcarnosas, glabras, glandulosas, lineares, às vezes escamiformes, lâminas 1-8 × 0,2-0,5 mm, ápice acuminado, base atenuada, margem inteira, lisa. Brácteas e bractéolas decíduas, margem lisa. Racemos pedunculados, terminais, cilíndricos, $1-10 \mathrm{~cm}$ compr., densifloros. Flores 1,5-2,2 mm compr., brancas, branco-rosadas, creme, pedicelos 0,4-0,8 mm compr., glabros, reflexos na frutificação. Sépalas externas glabras, glandulosas, ápice agudo, margem lisa; uma sépala largo-ovada, 1-1,3 mm compr.; duas sépalas livres e iguais entre si, elípticas, 0,7-0,9 mm compr.; sépalas internas glabras, glandulosas ou não, elípticas, obovadas ou espatuladas, 1,5-2,2 mm compr., ápice obtuso ou arredondado, base unguiculada. Pétalas laterais glabras, sem glândulas, elípticas a rômbicas, 1,2-1,5 mm compr., com ápice arredondado; carena cristada, glandulosa no dorso, crista com $0,4-0,7 \mathrm{~mm}$ compr., com 5-6 lobos simples e bífidos. Ovário glabro, glanduloso, suborbicular. Cápsulas glabras, glandulosas, elípticas a orbiculares, 1-1,5 mm compr., não estipitadas, não aladas. Sementes pilosas, ovoides, 0,6-0,8 mm compr., sem apêndice membranáceo.

Material selecionado: BRASIL. PARAnÁ: Arapoti, Rio das Cinzas, Barra das Perdizes, 24-X-1961, G. Hatschbach 8494 (MBM); Ipiranga, Rio Tibagi, 29-III-1947, G. Hatschbach 647 (MBM, PACA, RB); Jaguariaíva, estrada de acesso ao Parque Estadual do Cerrado, 24ำ' $12^{\prime} 34,6^{\prime \prime S}, 49^{\circ} 41^{\prime} 02,5^{\prime \prime} \mathrm{W}, 10-\mathrm{I}-2007$, R. Lüdtke 732 (ICN); Lapa, Pedra Alta, 27-II-1982, R. Kummrow \& J.G. Stutts 1839 (MBM); Palmeira, BR 277, km 144, Recanto dos Papagaios, 25 27'59,3"S, 4946'05,1"W, 22-II-2006, R. Lüdtke, 531 (ICN); Piraquara, Florestal, 5-I-1947, G. Hatschbach 571 (MBM, PACA, RB); Ponta Grossa, Parque Estadual Vila Velha, 3-XI-1928, F.C. Hoehne s.n. (MBM299126, SP23352); Tibagi, Cânion Guartelá, 14-IX-1996, F.G. Paião s.n. (FUEL30101); Tijucas do Sul, 46 km S de Curitiba, 14-II-1978, A. Krapovickas \& C.L. Cristóbal 33599 (CTES, F, MBM); Ventania, Fazenda Santa Inês, 22-VI-2005, D.A. Estevan et al. 741 (FUEL, ICN). SantaCcatarina: Mafra, 26-I-1953, R. Reitz \& R. Klein 5272 (HBR, NY, PACA); Ponte Alta (Curitibanos), $3 \mathrm{~km}$ de Ponte Alta, 4-XII-1956, L.B. Smith \& R. Klein 8265 (HBR, NY).

Polygala tenuis ocorre no Brasil: Rio Grande do Norte, Bahia, Mato Grosso, Goiás, Distrito Federal, Minas Gerais, São Paulo, Paraná e Santa Catarina (Wurdack \& Smith 1971, Marques 1979, Marques $\&$ Gomes 2002, Pastore 2006). Pode ser encontrada em campos úmidos, brejos, beira de riachos e solos encharcados. Floresce e frutifica em todos os meses do ano.

Polygala tenuis caracteriza-se por apresentar folhas diminutas, escamiformes, sésseis, glândulas no caule, folhas, flores e frutos, e sementes sem apêndice membranáceo.

3.31. Polygala timoutoides Chodat, Mém. Soc. Phys. et d'Hist. Nat. Genève 30(8): 112. 1889.

Figura 13e-j

Ervas eretas a decumbentes, 9-30 cm alt. Caule folioso, cilíndrico, fortemente estriado ou anguloso, escassamente piloso, com tricomas curtos, glanduloso, simples ou com ramificação basal, mediana ou terminal. Folhas sésseis, alternas ou 4-5 verticiladas na base e alternas no ápice da planta, papiráceas, glabras, glandulosas, estreito-ovadas, estreito-elípticas, elípticas ou oblongas, lâminas 5-28 × $1 \mathrm{~mm}$; ápice mucronado, agudo ou acuminado, base aguda, arredondada, atenuada ou cuneada, margem irregular ou serreada, lisa. Brácteas e bractéolas persistentes, margem ciliada. Racemos pedunculados, terminais, curtos e largo-cilíndricos, 1-5,5 cm compr., densifloros. Flores 2,5-3,5 mm compr., creme-esverdeadas, esverdeadas ou esverdeadas com manchas rosadas; pedicelos 0,1-0,2 mm compr., glabros, eretos ou patentes na frutificação. Sépalas externas glabras, glandulosas, ápice agudo, margem inteira; uma sépala largo-ovada, 1,2-1,7 mm compr.; duas sépalas livres e iguais entre si, ovadas, 1,1-1,5 mm compr.; sépalas internas glabras, glandulosas, orbiculares a suborbiculares, 2,5-3,8 mm compr., ápice obtuso ou arredondado, base aguda. Pétalas laterais glabras, glandulosas, elípticas, 1,8-2,5 mm compr., ápice obtuso; carena cristada, glandulosas no dorso, crista 0,4-0,5 mm compr., com 2 lobos bífidos. Ovário glabro, glanduloso, suborbicular ou oblongo. Cápsulas glabras, glandulosas, suborbiculares ou cordiformes, 1,5-2 mm compr., não estipitadas, não aladas. Sementes pubérulas ou pubescentes, elipsoides ou oblongo-orbiculares, 1,1-1,8 mm compr., com apêndice membranáceo profundamente bilobado, atingindo de $1 / 2$ a $2 / 3$ do comprimento da semente.

Material selecionado: BRASIL. PARANÁ: Imbituva, Rio Imbituva, 5-III-1982, R. Kummrow et al. 1867 (MBM); Ipiranga, Rio Tibagi, 28-III-1947, G. Hatschbach 644 (MBM, RB, SP); Jaguariaíva, 5-II-1910, P. Dusén 9205 (S); Palmeira, BR 277, próximo ao Haras Valente, 4-II-1999, G. Hatschbach 


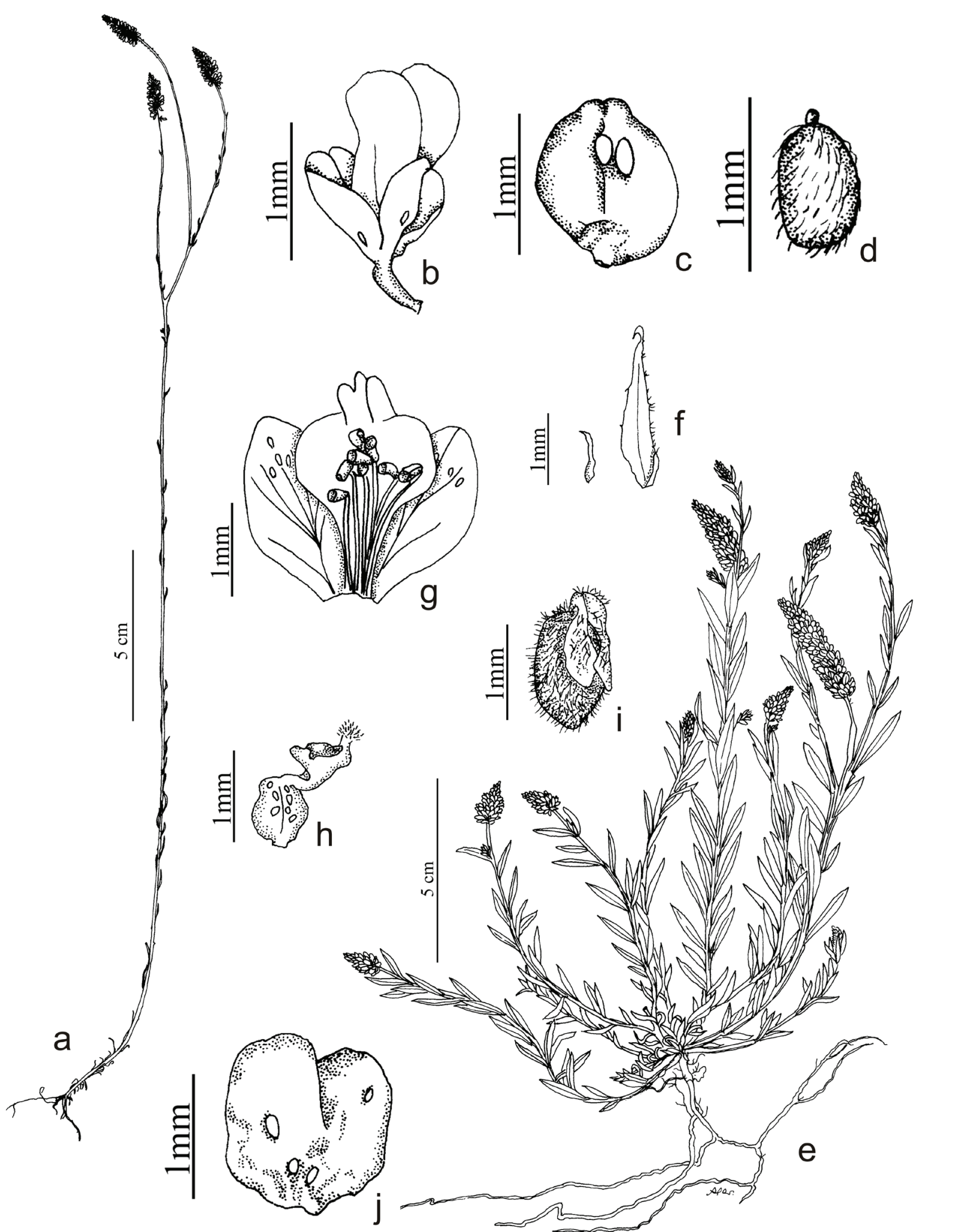

Figura 13. a-d. Polygala tenuis. a. Hábito. b. Cálice. c. Fruto. d. Semente. e-j. Polygala timoutoides. e. Hábito. f. Bractéola e bráctea. g. Corola e androceu em secção longitudinal. h. Gineceu. i. Semente. j. Fruto. [a, c, d: Dusén 15115 (S); b: Lüdtke 531 (ICN); e-j: Lüdtke $100(\mathrm{ICN})]$.

Figure 13. a-d. Polygala tenuis. a. Habit. b. Calyx. c. Fruit. d. Seed. e-j. Polygala timoutoides. e. Habit. f. Bracteole and bract. g. Corolla and androecium in longitudinal section. h. Gynoecium. i. Seed. j. Fruit. [a, c, d: Dusén 15115 (S); b: Lüdtke 531 (ICN); e-j: Lüdtke 100 (ICN)]. 
\& S.R. Ziller 68917 (MBM); Ponta Grossa, estrada para Palmeira, $25^{\circ} 15^{\prime} 32,0^{\prime \prime} \mathrm{S}, 50^{\circ} 08^{\prime} 54,3^{\prime \prime} \mathrm{W}$, 11-I-2007, R. Lüdtke 747 (ICN); Porto Amazonas, 20-IV-2000, E. Barbosa et al. 464 (MBM); Tibagi, Fazenda Monte Alegre, 14-XI-1952, G. Hatschbach 2862 (HAS, MBM, PEL); Rio Grande do Sul: Bojuru, 31 ${ }^{\circ} 40^{\prime} 17,2^{\prime \prime} \mathrm{S}, 51^{\circ} 24^{\prime} 34,6 " \mathrm{~W}, 24-\mathrm{I}-2005$, R. Lüdtke 388 (ICN); Cristal, BR 116, km 435, 26-I-2005, R. Lüdtke 395 (ICN); Guaíba, Fazenda São Maximiano, 11-III-1988, S.A.L. Bordignon 983 (ICN); Nonoai, III-1945, B. Rambo 28166 (PACA); Passo Fundo, BR 285, km 308, 26-XII-2002, R. Lüdtke 100 (ICN); Pelotas, 27-II-1958, J. Sacco 922 (PACA, PEL); Rosário do Sul, BR 290, 26 km do trevo, 9-I-2003, R. Lüdtke 153 (ICN); São Pedro do Sul, Parada Linck, 4-I-1977, M. Fleig 266 (ICN); Sapucaia do Sul, 1-III-1949, B. Rambo 40807 (PACA); Torres, Lagoa de Itapeva, 20-XI-1970, M.L. Porto s.n. (ICN7875); Viamão, Hospital Colônia de Itapuã, 30²1'39,7"S, 5100'12,3"W, 9-IV-2007, R. Lüdtke 765 (ICN). SANTA CATARINA: Garopaba, Praia da Ferrugem, 12-X-1989, L.H. Pankowski 53 (HAS); Imbituba, Itapirubá, 12-II-1978, G. Hatschbach \& E. Zardini 41000 (MBM); Irineópolis (Porto União), 5-I-1962, R. Reitz \& R. Klein 11561 (HBR); Palhoça, Campo do Massiambú, 18-XII-1952, R. Reitz 4823 (HBR, NY, S); Sombrio, (Araranguá), 28-XII-1945, R. Reitz 1848 (F, HBR, NY, S, U).

Polygala timoutoides ocorre no Paraguai, Argentina e Brasil: Minas Gerais, São Paulo, Paraná, Santa Catarina e Rio Grande do Sul (Wurdack \& Smith 1971, Marques 1988, Bernardi 2000, Marques \& Gomes 2002, Lüdtke \& Miotto 2004). É encontrada em campos úmidos e secos, graminosos e subarbustivos, beiras de estradas, baixadas úmidas, brejos, restingas, dunas fixas, campos arenosos e terrenos baldios. Floresce e frutifica em todos os meses do ano.

Os racemos densos e largo-cilíndricos, as flores branco-esverdeadas e a presença de glândulas em toda a planta, são características marcantes desta espécie.

\section{Agradecimentos}

Aos curadores dos herbários citados, pelo empréstimo de material. À CAPES pela bolsa de doutorado concedida à primeira Autora e ao $\mathrm{CNPq}$ pelas bolsas de Produtividade em Pesquisa concedidas às segunda e terceira autoras. À ilustradora botânica
Anelise Scherer de Souza Nunes. Aos colegas Angelo Alberto Schneider e Rafael Trevisan por todo o apoio durante a realização do doutorado.

\section{Literatura citada}

Aguiar, A.C.A. 2005. Estudos taxonômicos sobre o gênero Polygala L. subgênero Hebeclada (Chodat) Blake (Polygalaceae) no Brasil. Dissertação de Mestrado, Universidade Estadual de Campinas, Campinas.

Aguiar, A.C.A., Marques, M.C.M. \& Yamamoto, K. 2008. Taxonomia das espécies de Polygala L. subg. Hebeclada (Chodat) Blake (Polygalaceae) ocorrentes no Brasil. Revista Brasileira de Biociências 6: 81-109.

Angely, J. 1965. Flora Analítica do Paraná. Coleção Saint-Hilaire. Edições Phyton, São Paulo, v.7, fasc. 1, pp. 403-405.

Bennett, A.W. 1874. Polygalaceae. In: C.F.P. Martius (ed.). Flora Brasiliensis, v.13, fasc. 3, pp. 1-45.

Bernardi, L.F. 2000. Consideraciones taxonómicas y fitogeográficas acerca de 101 Polygalae Americanas. Cavanillesia Altera 1: 1-456.

Chodat, R. 1893. Monographia Polygalacearum. Mémoires de la Société de Physique et d1Histoire Naturelle de Genève 31: 1-500.

Chung, I.W., Moore, N.A. \& Oh, W.K. 2002. Behavioural pharmacology of polygala saponins indicatives potential antipsychotic efficacy. Pharmacology Biochemestry and Behavior 71: 191-195.

Daros, M.D.R, Matos, F.J.D.A. \& Parente, J.P. 1996. A new triterpenoid saponin, bredemeyeroside $\mathrm{B}$, from the roots of Bredemeyera floribunda. Planta Medica 62: 523-527.

Eriksen B. \& Persson, C. 2007. Polygalaceae. In: K. Kubitzki (ed.). The Families and Genera o Vascular Plants v.5, Flowering Plants. Eudicots. Springer, Berlin.

Eriksen, B., Stahl, B. \& Persson, C. 2000. Polygalaceae. In: G. Harling \& L. Andersson (eds.). Flora of Ecuador, v.65, pp. 1-132.

Font Quer, P. 1979. Diccionario de Botánica. Editorial Labor, Barcelona.

Grondona, E.M. 1948. Las especies argentinas del género Polygala. Darwiniana 8: 279-405.

Harbone, J.B. \& Baxter, H. 1995. Phytochemical dictionary: a handbook of bioactive compounds from plantts. Taylor \& Francis, London.

Holmgren, P.K. \& Holmgren, N.H. 2008. Index Herbariorum on the Internet. http://sciweb.nybg. org/science 2/IndexHerbariorum.asp (acesso em 20.01.2008).

Ikeya, Y., Sugama, K., Okada, M. \& Mitsuhashi, H. 1991. Four new phenolic glycosides from Polygala tenuifolia. Chemical \& Pharmaceutical Bulletin 39: 2600-2605. 
Lüdtke, R. 2008. A família Polygalaceae na Região Sul do Brasil. Tese de Doutorado. Universidade Federal do Rio Grande do Sul, Porto Alegre.

Lüdtke, R. \& Miotto, S.T.S. 2004. O gênero Polygala L. (Polygalaceae) no Rio Grande do Sul, Brasil. Revista Brasileira de Biociências 2: 49-102.

Lüdtke, R. \& Miotto, S.T.S. 2007. Polygala riograndensis (Polygalaceae), a new species from Southern Brazil. Novon 17: 40-42.

Lüdtke, R., Souza-Chies, T.T. \& Miotto, S.T.S. 2008. Bredemeyera Willd. e Securidaca L. (Polygalaceae) na Região Sul do Brasil. Revista Brasileira de Biociências 6: 69-79.

Lüdtke, R., Souza-Chies, T.T. \& Miotto, S.T.S. 2009. O gênero Monnina Ruiz \& Pav. (Polygalaceae) na Região Sul do Brasil. Acta Botanica Brasilica 23: 175-195.

Marques, M.C.M. 1979. Revisão das espécies do gênero Polygala L. (Polygalaceae) do Estado do Rio de Janeiro. Rodriguésia 31: 69-339.

Marques, M.C.M. 1984a. Polígalas do Brasil - I. Seção Acanthocladus (Klotzsch ex Hassk.) Chodat. (Polygalaceae). Rodriguésia 36: 3-10.

Marques, M.C.M. 1984b. Polígalas do Brasil III. Seção Gymnospora Chod. do gênero Polygala L. (Polygalaceae). Rodriguésia 36: 31-34.

Marques, M.C.M. 1988. Polígalas do Brasil - V. Seção Polygala (Polygalaceae). Arquivos do Jardim Botânico do Rio de Janeiro 29: 1-114.

Marques, M.C.M. 2003. Estudo taxonômico do gênero Polygala L. subgênero Ligustrina (Chodat) Paiva (Polygalaceae). Tese de Doutorado, Universidade Federal do Rio de Janeiro, Rio de Janeiro.

Marques, M.C.M. \& Gomes, K. 2002. Polygalaceae. In: M.G.L.Wanderley, G.J. Shepherd \& A.M. Giulietti (eds.). Flora Fanerogâmica do Estado de São Paulo. FAPESP / HUCITEC, São Paulo, v.2, pp. 229-259.

Marques, M.C.M. \& Peixoto, A.L. 2007. Estudo taxonômico de Polygala L. subgênero Ligustrina (Chodat) Paiva (Polygalaceae). Rodriguésia 58: 95-146.

Monzou, A.P., Bulteau, L. \& Raymond, G. 1999. The effects of Securidaca longepedunculata root extract on ionic currents and contraction of cultured rat skeletal muscle cells. Journal of Ethnopharmacology 65: 157-164.
Obi, C.L., Potgieter, N. \& Randima, L.P. 2002. Antibacterial activities of five plants against some medically significant human bacteria. South Africa Journal of Science 98: 25-28.

Paiva, J.A.R. 1998. Polygalarum Africanarum et Madagascariensium prodomus atque gerontogaei generis Heterosamara Kuntze, a genere Polygala segregati et a nobis denuo recepti, synopsis monographica. Fontqueria 50: $1-346$.

Pastore, J.F.B. 2006. A familia Polygalaceae Hoffmanseg \& Link no Distrito Federal, Brasil. Dissertação de Mestrado, Universidade Federal de Brasília, Brasília.

Pastore, J.F.B., Cardoso, D.B.O.S. \& Aymard C., G.A. 2010. Synopsis, new combinations, and synonyms in Acanthocladus (Polygalaceae). Novon 20: 317-324.

Pastore, J.F., Marques, M.C.M., Medeiros, E.S., Lüdtke, R. 2012. Polygalaceae. In: R.C. Forzza, A. Costa, B.M.T. Walter, J.R. Pirani, M.P. Morim, L.P. Queiroz, G. Martinelli, A.L. Peixoto, M.A.N. Coelho, J.F.A. Baumgratz, J.R. Stehmann, L.G. Lohmann, M. Hopkins. Lista de Espécies da Flora do Brasil. Jardim Botânico do Rio de Janeiro. http://floradobrasil.jbrj.gov.br/2012/ FB020541 (acesso em 07.01.2013).

Pereira, B.M.R., Daros, M.D.R., Parente, J.P. \& Matos, F.J.D.A. 1996. Bredemeyeroside d, a noval triterpenoid saponin from Bredemeyera floribunda: A potent snake venom antidote activity on mice. Phytotherapy Research 10: 666-669.

Pizzolatti, M.G., Cunha, A.J.R., Pereira, W.S. \& Monache, F.D. 2004. A new styryl-2-pyrone derivative from Polygala sabulosa (Polygalaceae). Biochemical Systematics and Ecology 32: 603-606.

Radford, A.E., Dickison, W.C., Massey, J.R. \& Bell, C.R. 1974. Vascular plant systematics. Harper \& Row, New York.

The International Plant Names Index. 2004. http://www. ipni.org/html (acesso em 01.03.2008).

Wurdack, J.J. \& Smith, L.B. 1971. Poligaláceas. In: R. Reitz (ed.). Flora Ilustrada Catarinense, Herbário Barbosa Rodrigues, Itajaí. 